Supporting Information

\title{
Solvent-Induced Sign Inversion of Circularly Polarized Luminescence: Control of Excimer Chirality by Hydrogen Bonding
}

Kazuto Takaishi, ${ }^{*}$ Kazuhiro Iwachido, and Tadashi Ema*

Division of Applied Chemistry, Graduate School of Natural Science and Technology, Okayama University, Tsushima, Okayama 700-8530 Japan

\section{Table of contents}

1. General information $\quad$ S2

2. Synthetic methods and characterization S3

3. UV-Vis, CD, FL, CPL, and ESI-MS spectra S12

$\begin{array}{ll}\text { 4. DFT calculations } & \text { S20 }\end{array}$

5. ${ }^{1} \mathrm{H}$ NMR and ${ }^{13} \mathrm{C}$ NMR spectra $\quad$ S22

6. Coordinates of optimized structures $\quad$ S46

$\begin{array}{ll}\text { 7. References } & \text { S69 }\end{array}$ 


\section{General information}

Melting points were measured on a Yanaco melting point apparatus (uncorrected). Optical rotations were measured on a Horiba SEPA-300. IR spectra were recorded on a Shimadzu IRAffinity-1. ${ }^{1} \mathrm{H}$ NMR and ${ }^{13} \mathrm{C}$ NMR spectra were recorded on a JEOL JNM-ECS400. Data are reported as follows: chemical shifts in ppm using the residual solvent peak as an internal standard, integration, multiplicity $(\mathrm{s}=$ singlet, $\mathrm{d}=$ doublet, $\mathrm{t}=$ triplet, $\mathrm{q}=$ quartet, $\mathrm{m}=$ multiplet, $\mathrm{dd}=$ doublet of doublets, ddd $=$ doublet of double doublets), coupling constants $(\mathrm{Hz})$. High-resolution mass spectra were performed on an Agilent G6520+G4240. UV-Vis spectra were recorded on a Shimadzu UV-2600. CD spectra were recorded on a JASCO J-1500. Fluorescence spectra were recorded on a JASCO FP-750. CPL spectra were measured on a JASCO CPL-200. TLC analyses were carried out on glass sheets coated with Merck Silica gel $60 \mathrm{~F}_{254}(0.25 \mathrm{~mm})$. Column chromatography was performed on silica gel (Fuji Silysia BW-127 ZH, 100-270 mesh). 


\section{Synthetic methods and characterization}

Compounds $(R)-\mathbf{1 1},(R)-\mathbf{1 3}$, and $\mathbf{2 0}$ were commercially available. Compounds $(R)-\mathbf{1 2}{ }^{\mathrm{S} 1},(R)-\mathbf{1} \mathbf{4}^{\mathrm{S} 2}$, $(R)-\mathbf{1 5}{ }^{\mathrm{S} 3},(R)-\mathbf{1 6}^{\mathrm{S} 4},(R)-\mathbf{1 7}^{\mathrm{S} 5}, \mathbf{1 8}^{\mathrm{S} 6}, \mathbf{2 1}^{\mathrm{S} 7}$ were synthesized according to the literature. Compounds $(R, R)-\mathbf{2}-\mathbf{9},(R)-\mathbf{1 0}$ and $\mathbf{1 9}$ were synthesized as follows. $(S, S)-\mathbf{2}$ was synthesized in a similar manner to that for $(R, R)-\mathbf{2}$ with the exception that $(S)-\mathbf{1 1}$ was used as a starting material.

Scheme S1. Synthesis of 2-10

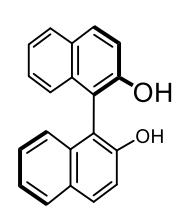

(R)-BINOL (11)<smiles>Cc1cc2ccccc2c(-c2c(O)c(C)cc3ccccc23)c1O</smiles><smiles>Oc1c(-c2ccccc2)cc2ccccc2c1-c1c(O)c(-c2ccccc2)cc2ccccc12</smiles>

(R)-13

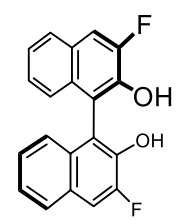

$(R)-14$

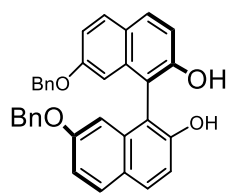

$(R)-15$

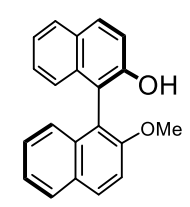

(R)-16
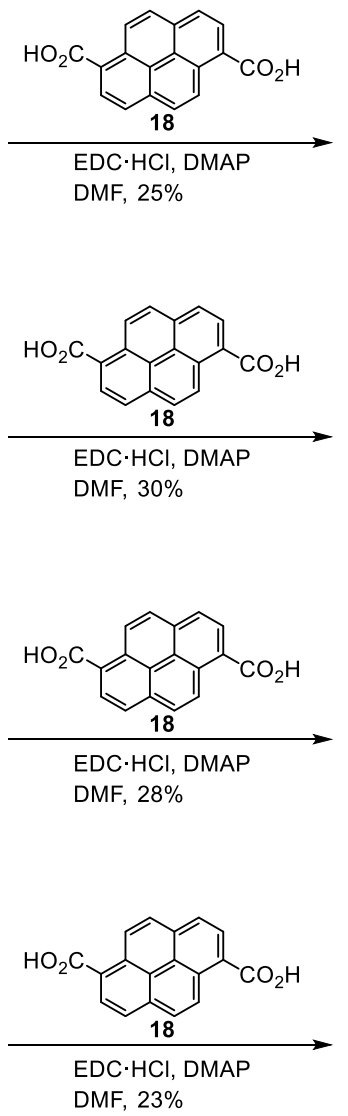

DMF, 23\%

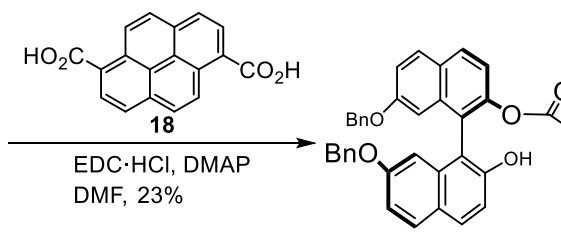

(R,R)-5
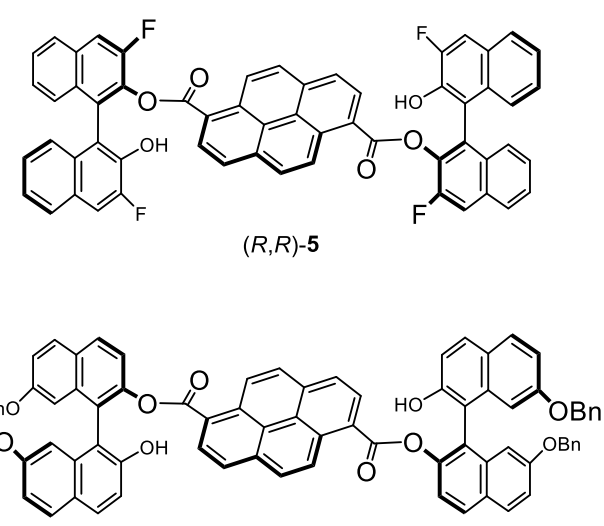

$(R, R)-6$
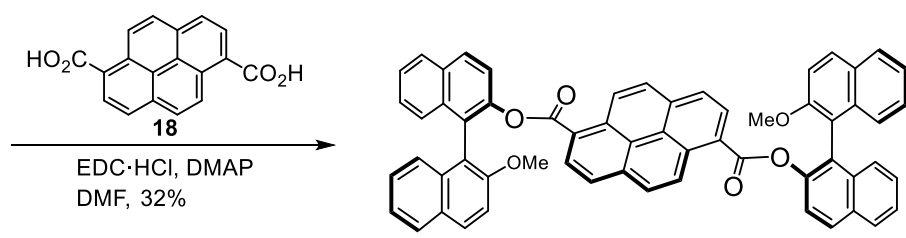

$(R, R)-7$ 


\section{Scheme S1. continued}

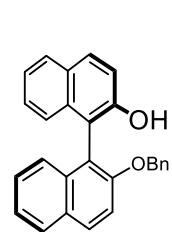

(R)-17<smiles>[B]c1ccc2ccc3c(Br)ccc4ccc1c2c43</smiles>

21

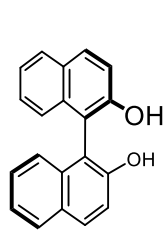

(R)-BINOL (11)

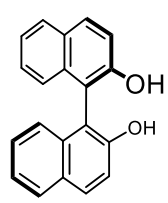

(R)-BINOL (11)

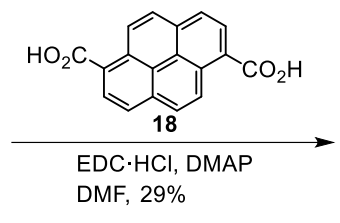

i) paraformaldehyde

$\underset{\text { ii) } \mathrm{SOCl}_{2} \text {, pyridine }}{\stackrel{\mathrm{n}-\mathrm{BuLi}}{\text { hexane/benzene/ } \mathrm{Et}_{2} \mathrm{O}}}$
$\mathrm{CH}_{2} \mathrm{Cl}_{2}$
$36 \%$ (2 steps)<smiles>ClCc1ccc2ccc3c(CCl)ccc4ccc1c2c43</smiles>

19
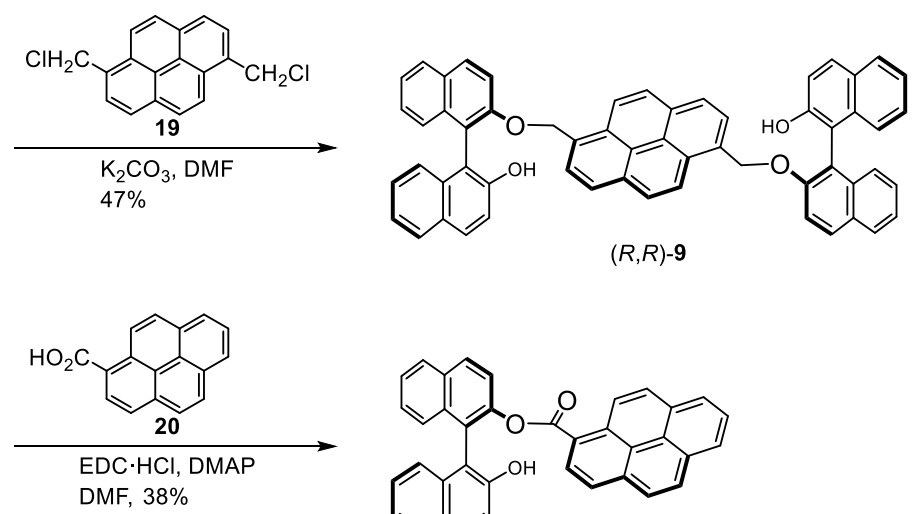

(R)-10 


\section{Synthesis of $(R, R)-2$}

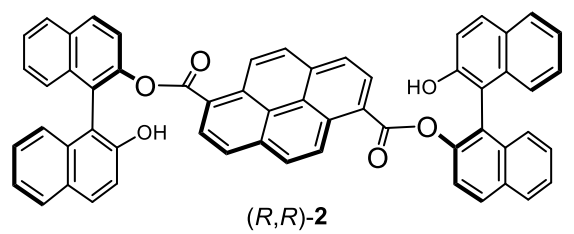

A solution of $(R)$-BINOL (11) (1.00 g, $3.49 \mathrm{mmol})$, pyrene-1,6-dicarboxylic acid (18) (208 mg, $717 \mu \mathrm{mol}), \mathrm{EDC} \cdot \mathrm{HCl}(780 \mathrm{mg}, 4.07 \mathrm{mmol})$, and DMAP $(1.01 \mathrm{~g}, 8.27 \mathrm{mmol})$ in dry DMF (16 mL) was stirred at $40{ }^{\circ} \mathrm{C}$ for $13 \mathrm{~h}$. The reaction was quenched with water, and the product was extracted with $\mathrm{CHCl}_{3}$ (twice). The organic layer was washed successively with water (three times) and brine. After dried over $\mathrm{Na}_{2} \mathrm{SO}_{4}$, the solvent was evaporated to give a residue. The residue was purified by column chromatography $\left(\mathrm{SiO}_{2}, \mathrm{CHCl}_{3}\right)$, $\mathrm{GPC}\left(\mathrm{CHCl}_{3}\right)$, and recrystallization $\left(\mathrm{CHCl}_{3} /\right.$ hexane $)$ to afford $(R, R)-2(146 \mathrm{mg}, 177 \mu \mathrm{mol}, 25 \%)$ as a yellow powder.

mp $161-165{ }^{\circ} \mathrm{C} ;[\alpha]_{\mathrm{D}}^{28}=+449\left(\mathrm{CHCl}_{3}, c 0.10\right)$; IR $(\mathrm{KBr}) 3481,3057,3015,1717,1622,1508$, 1472, 1431, 1381, 1346, 1250, 1209, 1152, 1072, 1049, 976, 853, 818, 773, $748 \mathrm{~cm}^{-1}$; ${ }^{1} \mathbf{H}$ NMR $\left(400 \mathrm{MHz}, \mathrm{CDCl}_{3}\right) \delta 5.35(\mathrm{~s}, 2 \mathrm{H}), 7.20-7.30(\mathrm{~m}, 4 \mathrm{H}), 7.30-7.40(\mathrm{~m}, 4 \mathrm{H}), 7.42(\mathrm{~d}, J=4.0 \mathrm{~Hz}, 4 \mathrm{H})$, 7.55-7.63 (m, 2H), 7.67 (d, $J=8.8 \mathrm{~Hz}, 2 \mathrm{H}), 7.75-7.85$ (m, 6H), 7.89 (d, $J=8.4 \mathrm{~Hz}, 2 \mathrm{H}), 7.96$ (d, $J$ $=8.0 \mathrm{~Hz}, 2 \mathrm{H}), 8.05(\mathrm{~d}, J=8.0 \mathrm{~Hz}, 2 \mathrm{H}), 8.19(\mathrm{~d}, J=8.6 \mathrm{~Hz}, 2 \mathrm{H}), 8.71(\mathrm{~d}, J=9.5 \mathrm{~Hz}, 2 \mathrm{H}) ;{ }^{13} \mathbf{C} \mathbf{N M R}$ $\left(100 \mathrm{MHz}, \mathrm{CDCl}_{3}\right) \delta 114.5,118.7,122.4,123.3,123.66,123.74,124.0,125.0,125.4,126.2,126.7$, 126.8, 127.3, 127.9, 128.5, 128.7, 128.8, 129.1, 129.4, 130.89, 130.91, 131.3, 132.7, 133.4, 134.0, 134.1, 148.8, 152.3, 167.2; HR MS $\left(\right.$ ESI $\left.^{+}\right)$Calcd for $\mathrm{C}_{58} \mathrm{H}_{34} \mathrm{O}_{6} \mathrm{Na}: 849.2248[\mathrm{M}+\mathrm{Na}]^{+}$. Found: 849.2231.

\section{Synthesis of $(R, R)-3$}

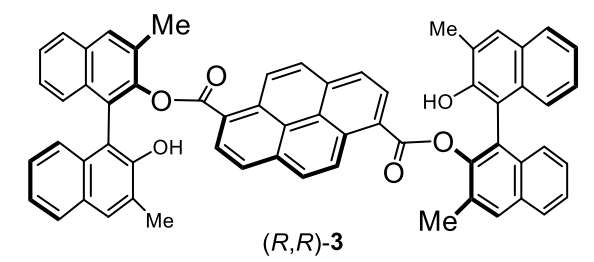

A solution of $(R)-12(287 \mathrm{mg}, 913 \mu \mathrm{mol})$, pyrene-1,6-dicarboxylic acid (18) $(53.0 \mathrm{mg}, 183 \mu \mathrm{mol})$, $\mathrm{EDC} \cdot \mathrm{HCl}(220 \mathrm{mg}, 1.15 \mathrm{mmol})$, and DMAP $(280 \mathrm{mg}, 2.29 \mathrm{mmol})$ in dry DMF $(4.5 \mathrm{~mL})$ was stirred at $40{ }^{\circ} \mathrm{C}$ for $20 \mathrm{~h}$. The reaction was quenched with water, and the product was extracted with $\mathrm{CHCl}_{3}$ (twice). The organic layer was washed successively with water (three times) and brine. After dried over $\mathrm{Na}_{2} \mathrm{SO}_{4}$, the solvent was evaporated to give a residue. The residue was purified by column chromatography $\left(\mathrm{SiO}_{2}, \mathrm{CHCl}_{3} /\right.$ hexane $\left.=3 / 1\right)$ to afford $(R, R)-3(48.4 \mathrm{mg}, 54.8 \mu \mathrm{mol}, 30 \%)$ as a yellow powder.

mp $185-189{ }^{\circ} \mathrm{C} ;[\alpha]_{\mathrm{D}}^{28}=+409\left(\mathrm{CHCl}_{3}, c\right.$ 0.12); IR (KBr) 3518, 3061, 2953, 2914, 2855, 1721, 
1626, 1499, 1462, 1437, 1381, 1360, 1254, 1207, 1146, 1092, 1047, 974, 853, 820, 777, $748 \mathrm{~cm}^{-1}$; ${ }^{1} \mathrm{H}$ NMR (400 MHz, $\left.\mathrm{CDCl}_{3}\right) \delta 2.37$ (s, 4H), 2.39 (s, 2H), 2.58 (s, 4H), 2.60 (s, 2H), 5.43 (br s, 2H), $7.17(\mathrm{~d}, J=8.1 \mathrm{~Hz}, 2 \mathrm{H}), 7.20-7.40(\mathrm{~m}, 6 \mathrm{H}), 7.50-7.56(\mathrm{~m}, 2 \mathrm{H}), 7.58(\mathrm{~d}, J=7.0 \mathrm{~Hz}, 2 \mathrm{H}), 7.70(\mathrm{~d}, J$ $=7.7 \mathrm{~Hz}, 2 \mathrm{H}), 7.82(\mathrm{~d}, J=9.4 \mathrm{~Hz}, 2 \mathrm{H}), 7.92(\mathrm{~d}, J=8.0 \mathrm{~Hz}, 2 \mathrm{H}), 7.97(\mathrm{dd}, J=4.0,8.3 \mathrm{~Hz}, 4 \mathrm{H})$, 8.00-8.05 (m, 4H), 8.50-8.65 (m, 2H); ${ }^{13} \mathbf{C}$ NMR (100 MHz, $\left.\mathrm{CDCl}_{3}\right) \delta 17.2,17.6,114.2,123.5$, 123.6, 124.0, 124.6, 125.2, 125.9, 126.3, 126.6, 126.8, 127.4, 127.7, 128.3, 128.5, 129.0, 129.2, 129.3 130.0, 130.4, 130.7, 131.0, 132.6, 132.7, 133.3, 148.5, 151.4, 167.1; HR MS (ESI $\left.{ }^{+}\right)$Calcd for $\mathrm{C}_{62} \mathrm{H}_{42} \mathrm{O}_{6} \mathrm{Na}: 905.2874[\mathrm{M}+\mathrm{Na}]^{+}$. Found: 905.2833.

\section{Synthesis of $(R, R)-4$}

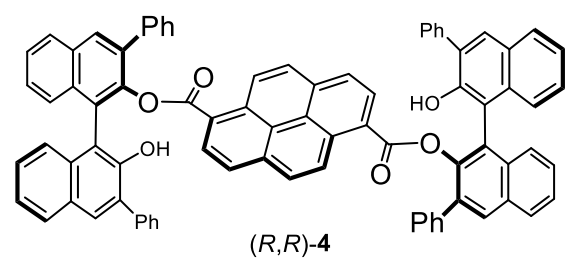

A solution of (R)-13 (204 mg, $465 \mu \mathrm{mol})$, pyrene-1,6-dicarboxylic acid (18) (34.0 mg, $117 \mu \mathrm{mol})$, $\mathrm{EDC} \cdot \mathrm{HCl}(109 \mathrm{mg}, 569 \mu \mathrm{mol})$, and DMAP $(133 \mathrm{mg}, 1.09 \mathrm{mmol})$ in dry DMF $(2.1 \mathrm{~mL})$ was stirred at $40{ }^{\circ} \mathrm{C}$ for $20 \mathrm{~h}$. The reaction was quenched with water, and the product was extracted with $\mathrm{CHCl}_{3}$ (twice). The organic layer was washed successively with water and brine. After dried over $\mathrm{Na}_{2} \mathrm{SO}_{4}$, the solvent was evaporated to give a residue. The residue was purified by column chromatography $\left(\mathrm{SiO}_{2}, \mathrm{CHCl}_{3} /\right.$ hexane $\left.=3 / 1\right)$ and $\mathrm{GPC}\left(\mathrm{CHCl}_{3}\right)$ to afford $(R, R)-\mathbf{4}(37.0 \mathrm{mg}, 32.7 \mu \mathrm{mol}, 28 \%)$ as a yellow powder.

mp $192-196{ }^{\circ} \mathrm{C} ;[\alpha]_{\mathrm{D}}^{27}=+62\left(\mathrm{CHCl}_{3}, c 0.11\right)$; IR $(\mathrm{KBr}) 3526,3053,2926,2851,1728,1622$, 1497, 1456, 1429, 1379, 1360, 1256, 1236, 1148, 1074, 1045, 974, 853, 818, 766, $748 \mathrm{~cm}^{-1} ;{ }^{1} \mathbf{H}$ NMR (400 MHz, CDCl $) \delta 5.63$ (br s, 2H), 7.25-7.40 (m, 20H), 7.40-7.46 (m, 2H), $7.49(\mathrm{~d}, J=8.7$ $\mathrm{Hz}, 2 \mathrm{H}), 7.50-7.55(\mathrm{~m}, 4 \mathrm{H}), 7.55-7.65(\mathrm{~m}, 6 \mathrm{H}), 7.65-7.72(\mathrm{~m}, 4 \mathrm{H}), 7.72-7.80(\mathrm{~m}, 6 \mathrm{H}), 8.07(\mathrm{t}, J=$ $8.0 \mathrm{~Hz}, 2 \mathrm{H}), 8.20(\mathrm{~d}, J=9.6 \mathrm{~Hz}, 2 \mathrm{H}) ;{ }^{13} \mathrm{C}$ NMR $\left(100 \mathrm{MHz}, \mathrm{CDCl}_{3}\right) \delta 115.5,123.7,123.8,124.1$, 124.5, 124.9, 126.0, 126.3, 126.87, 126.93, 127.6, 127.7, 127.8, 127.9, 128.3, 128.4, 128.5, 128.8, 129.1, 129.4, 129.5, 129.67, 129.73, 130.3, 130.8, 131.4, 132.6, 133.1, 133.3, 135.3, 137.8, 146.6, 149.8, 167.2; HR MS (ESI ${ }^{+}$) Calcd for $\mathrm{C}_{82} \mathrm{H}_{50} \mathrm{O}_{6} \mathrm{Na}: 1153.3500[\mathrm{M}+\mathrm{Na}]^{+}$. Found: 1153.3458. 


\section{Synthesis of $(R, R)-5$}

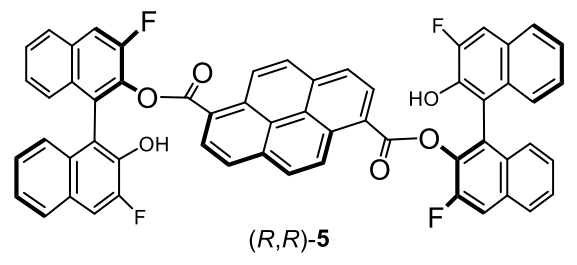

A solution of (R)-14 (667 mg, $2.06 \mathrm{mmol})$, pyrene-1,6-dicarboxylic acid (18) (125 mg, $431 \mu \mathrm{mol})$, $\mathrm{EDC} \cdot \mathrm{HCl}(499 \mathrm{mg}, 2.60 \mathrm{mmol})$, and DMAP (638 mg, $5.22 \mathrm{mmol})$ in dry DMF (10 mL) was stirred at $40{ }^{\circ} \mathrm{C}$ for $17 \mathrm{~h}$. The reaction was quenched with water, and the product was extracted with $\mathrm{CHCl}_{3}$ (twice). The organic layer was washed successively with water (three times) and brine. After dried over $\mathrm{Na}_{2} \mathrm{SO}_{4}$, the solvent was evaporated to give a residue. The residue was purified by column chromatography $\left(\mathrm{SiO}_{2}, \mathrm{CHCl}_{3}\right)$ and $\mathrm{GPC}\left(\mathrm{CHCl}_{3}\right)$ to afford $(R, R)-5(88.6 \mathrm{mg}, 98.6 \mu \mathrm{mol}, 23 \%)$ as a yellow powder.

mp $144-149{ }^{\circ} \mathrm{C} ;[\alpha]_{\mathrm{D}}^{27}=+584\left(\mathrm{CHCl}_{3}, c 0.10\right)$; IR $(\mathrm{KBr}) 3482,3061,2928,2853,1734,1628$, $1473,1447,1418,1389,1362,1237,1148,1103,1042,976,851,820,773,748 \mathrm{~cm}^{-1} ;{ }^{1} \mathbf{H}$ NMR $\left(400 \mathrm{MHz}, \mathrm{CDCl}_{3}\right) \delta 5.50(\mathrm{~s}, 2 \mathrm{H}), 7.20-7.45(\mathrm{~m}, 10 \mathrm{H}), 7.56(\mathrm{~d}, J=11.2 \mathrm{~Hz}, 2 \mathrm{H}), 7.60(\mathrm{~d}, J=6.8 \mathrm{~Hz}$, 2H), $7.74(\mathrm{~d}, J=8.0 \mathrm{~Hz}, 2 \mathrm{H}), 7.90(\mathrm{~d}, J=10.8 \mathrm{~Hz}, 2 \mathrm{H}), 7.92(\mathrm{~d}, J=9.6 \mathrm{~Hz}, 2 \mathrm{H}), 7.97(\mathrm{~d}, J=8.4 \mathrm{~Hz}$, 2H), $7.99(\mathrm{~d}, J=7.2 \mathrm{~Hz}, 2 \mathrm{H}), 8.13(\mathrm{~d}, J=8.0 \mathrm{~Hz}, 2 \mathrm{H}), 8.77(\mathrm{~d}, J=9.4 \mathrm{~Hz}, 2 \mathrm{H}) ;{ }^{13} \mathbf{C}$ NMR $(100$ $\left.\mathrm{MHz}, \mathrm{CDCl}_{3}\right) \delta 106.0(\mathrm{~d}, J=13.9 \mathrm{~Hz}), 106.6(\mathrm{~d}, J=14.1 \mathrm{~Hz}), 113.2,114.0,115.5,115.6,115.7$, 116.3, 116.5, 116.6, 116.9, 117.4, $117.6(\mathrm{~d}, J=4.2 \mathrm{~Hz}), 117.8(\mathrm{~d}, J=5.8 \mathrm{~Hz}), 118.2(\mathrm{~d}, J=15.3 \mathrm{~Hz})$, 118.3, 118.6, $118.9(\mathrm{~d}, J=16.8 \mathrm{~Hz}), 119.6,119.8,120.0,121.4(\mathrm{~d}, J=6.7 \mathrm{~Hz}), 122.0,125.9(\mathrm{~d}, J=$ $13.0 \mathrm{~Hz}), 129.3(\mathrm{~d}, J=12.6 \mathrm{~Hz}), 136.6(\mathrm{~d}, J=196.7 \mathrm{~Hz}), 139.2(\mathrm{~d}, J=200.1 \mathrm{~Hz}), 148.0$; HR MS $\left(\mathrm{ESI}^{+}\right)$Calcd for $\mathrm{C}_{58} \mathrm{H}_{30} \mathrm{~F}_{4} \mathrm{O}_{6} \mathrm{Na}: 921.1871[\mathrm{M}+\mathrm{Na}]^{+}$. Found: 921.1867.

\section{Synthesis of $(R, R)-6$}

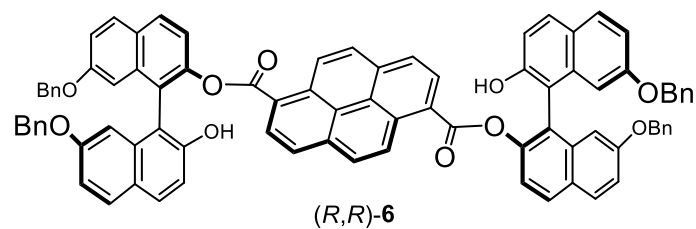

A solution of $(R)-\mathbf{1 5}(315 \mathrm{mg}, 632 \mu \mathrm{mol})$, pyrene-1,6-dicarboxylic acid (18) (38.8 mg, $134 \mu \mathrm{mol})$, EDC. HCl (137 mg, $715 \mu \mathrm{mol})$, and DMAP (173 mg, $1.42 \mathrm{mmol})$ in dry DMF (2.1 mL) was stirred at $40{ }^{\circ} \mathrm{C}$ for $18 \mathrm{~h}$. The reaction was quenched with water, and the product was extracted with $\mathrm{CHCl}_{3}$ (twice). The organic layer was washed successively with water (three times) and brine. After dried over $\mathrm{Na}_{2} \mathrm{SO}_{4}$, the solvent was evaporated to give a residue. The residue was purified by column chromatography $\left(\mathrm{SiO}_{2}, \mathrm{CHCl}_{3}\right), \mathrm{GPC}\left(\mathrm{CHCl}_{3}\right)$, and recrystallization $\left(\mathrm{CHCl}_{3} /\right.$ hexane $)$ to afford $(R, R)-6$ (38.4 $\mathrm{mg}, 30.7 \mu \mathrm{mol}, 23 \%)$ as a yellow powder. 
mp $112-118{ }^{\circ} \mathrm{C} ;[\alpha]_{\mathrm{D}}^{27}=+542\left(\mathrm{CHCl}_{3}, c 0.11\right) ; \mathbf{I R}(\mathrm{KBr}) 3422,3061,3028,1722,1620,1508$, 1452, 1431, 1379, 1337, 1252, 1211, 1153, 1069, 1045, 831, $737 \mathrm{~cm}^{-1} ;{ }^{\mathbf{1}} \mathbf{H} \mathbf{~ N M R}\left(400 \mathrm{MHz}, \mathrm{CDCl}_{3}\right)$ $\delta 5.31(\mathrm{AB} \mathrm{q}, \Delta v=13.5 \mathrm{~Hz}, J=9.4 \mathrm{~Hz}, 4 \mathrm{H}), 5.35(\mathrm{AB} \mathrm{q}, \Delta v=12.6 \mathrm{~Hz}, J=9.2 \mathrm{~Hz}, 4 \mathrm{H}), 5.72(\mathrm{br} \mathrm{s}$, 2H), 6.76 (br s, 2H), 6.85 (br s, 2H), 7.10-7.35 (m 26H), 7.46 (d, $J=7.0 \mathrm{~Hz}, 2 \mathrm{H}), 7.61$ (d, $J=7.6$ $\mathrm{Hz}, 2 \mathrm{H}), 7.63(\mathrm{~d}, J=7.1 \mathrm{~Hz}, 4 \mathrm{H}), 7.66(\mathrm{~d}, J=6.6 \mathrm{~Hz}, 2 \mathrm{H}), 7.73(\mathrm{~d}, J=6.5 \mathrm{~Hz}, 2 \mathrm{H}), 7.82(\mathrm{~d}, J=7.1$ $\mathrm{Hz}, 2 \mathrm{H}), 7.94(\mathrm{~d}, J=7.0 \mathrm{~Hz}, 2 \mathrm{H}), 8.36(\mathrm{~d}, J=7.4 \mathrm{~Hz}, 2 \mathrm{H}) ;{ }^{13} \mathbf{C} \mathbf{N M R}\left(100 \mathrm{MHz}, \mathrm{CDCl}_{3}\right) \delta 69.9$, 70.0, 105.4, 105.7, 113.6, 115.9, 116.5, 119.6, 119.8, 122.2, 123.5, 123.9, 124.7, 125.3, 126.8, 127.7, $127.9,128.0,128.1,128.5,128.6,128.8,129.0,129.8,130.1,130.3,130.6,130.9,133.5,135.0$, 135.1, 136.4, 136.9, 149.2, 152.5, 157.6, 158.1, 167.0; HR MS (ESI-) Calcd for $\mathrm{C}_{86} \mathrm{H}_{57} \mathrm{O}_{10}$ : $1249.3957[\mathrm{M}-\mathrm{H}]^{-}$. Found: 1249.3964.

\section{Synthesis of $(R, R)-7$}

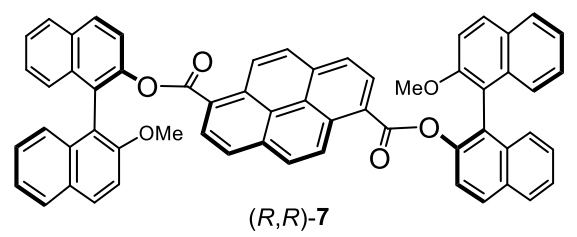

A solution of (R)-16 (140 mg, $466 \mu \mathrm{mol})$, pyrene-1,6-dicarboxylic acid (18) (68.2 mg, $235 \mu \mathrm{mol})$, $\mathrm{EDC} \cdot \mathrm{HCl}(357 \mathrm{mg}, 1.86 \mathrm{mmol})$, and DMAP (455 mg, $3.27 \mathrm{mmol})$ in dry DMF (3.0 mL) was stirred at $40{ }^{\circ} \mathrm{C}$ for $20 \mathrm{~h}$. The reaction was quenched with water, and the product was extracted with $\mathrm{CHCl}_{3}$ (twice). The organic layer was washed successively with water (three times) and brine. After dried over $\mathrm{Na}_{2} \mathrm{SO}_{4}$, the solvent was evaporated to give a residue. The residue was purified by column chromatography $\left(\mathrm{SiO}_{2}, \mathrm{CHCl}_{3} /\right.$ hexane $\left.=3 / 1\right)$, $\mathrm{GPC}\left(\mathrm{CHCl}_{3}\right)$, and recrystallization $\left(\mathrm{CHCl}_{3} /\right.$ hexane $)$ to afford $(R, R)-7$ (64.4 $\mathrm{mg}, 75.3 \mu \mathrm{mol}, 32 \%)$ as a yellow powder.

mp $143-147{ }^{\circ} \mathrm{C} ;[\alpha]_{\mathrm{D}}^{28}=+143\left(\mathrm{CHCl}_{3}, c\right.$ 0.10); IR (KBr) 3053, 3009, 2905, 2837, 1730, 1622, $1508,1474,1431,1358,1333,1250,1211,1152,1086,1049,976,854,808,773,746 \mathrm{~cm}^{-1} ;{ }^{1} \mathbf{H}$ NMR $\left(400 \mathrm{MHz}, \mathrm{CDCl}_{3}\right) \delta 3.70(\mathrm{~s}, 6 \mathrm{H}), 7.28-7.40(\mathrm{~m}, 12 \mathrm{H}), 7.51$ (ddd, $\left.J=1.7,6.4,8.2 \mathrm{~Hz}, 2 \mathrm{H}\right)$, $7.74(\mathrm{~d}, J=8.9 \mathrm{~Hz}, 2 \mathrm{H}), 7.80-7.88(\mathrm{~m}, 8 \mathrm{H}), 7.92(\mathrm{~d}, J=9.0 \mathrm{~Hz}, 2 \mathrm{H}), 8.01(\mathrm{~d}, J=8.2 \mathrm{~Hz}, 2 \mathrm{H}), 8.11$ $(\mathrm{d}, J=9.0 \mathrm{~Hz}, 2 \mathrm{H}), 8.73(\mathrm{~d}, J=9.4 \mathrm{~Hz}, 2 \mathrm{H}) ;{ }^{13} \mathbf{C} \mathbf{~ N M R}\left(100 \mathrm{MHz}, \mathrm{CDCl}_{3}\right) \delta 57.0,113.9,118.1$, $122.5,124.1,124.2,124.3,125.3,125.7,125.8,126.0,126.6,126.9,127.0,127.2,128.2,128.6$, $128.8,129.1,129.3,129.5,130.5,131.1,132.3,133.5,134.1,134.2,147.5,155.5,166.1$; HR MS $\left(\mathrm{ESI}^{+}\right)$Calcd for $\mathrm{C}_{60} \mathrm{H}_{38} \mathrm{O}_{6} \mathrm{Na}$ : 877.2561 [M+ Na] $]^{+}$. Found: 877.2547. 


\section{Synthesis of $(R, R)-8$}

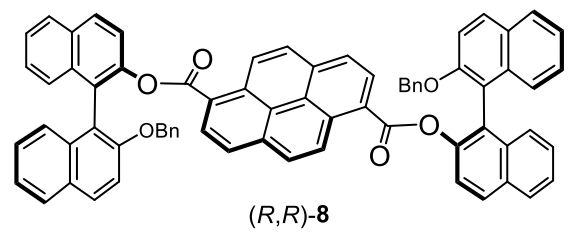

A solution of (R)-17 (549 mg, $1.46 \mathrm{mmol})$, pyrene-1,6-dicarboxylic acid (18) (211 mg, $727 \mu \mathrm{mol})$, $\mathrm{EDC} \cdot \mathrm{HCl}(840 \mathrm{mg}, 4.38 \mathrm{mmol})$, and DMAP $(1.57 \mathrm{~g}, 12.9 \mathrm{mmol})$ in dry DMF (5.0 mL) was stirred at $40{ }^{\circ} \mathrm{C}$ for $18 \mathrm{~h}$. The reaction was quenched with water, and the product was extracted with $\mathrm{CHCl}_{3}$ (twice). The organic layer was washed successively with water (three times) and brine. After dried over $\mathrm{Na}_{2} \mathrm{SO}_{4}$, the solvent was evaporated to give a residue. The residue was purified by column chromatography $\left(\mathrm{SiO}_{2}, \mathrm{CHCl}_{3} /\right.$ hexane $\left.=3 / 1\right)$, $\mathrm{GPC}\left(\mathrm{CHCl}_{3}\right)$, and recrystallization $\left(\mathrm{CHCl}_{3} /\right.$ hexane $)$ to afford $(R, R)-\mathbf{8}(211 \mathrm{mg}, 210 \mu \mathrm{mol}, 29 \%)$ as a yellow powder.

mp $122-127{ }^{\circ} \mathrm{C} ;[\alpha]_{\mathrm{D}}^{27}=+52\left(\mathrm{CHCl}_{3}, c 0.11\right)$; IR $(\mathrm{KBr}) 3053,2943,2872,1728,1622,1508$, 1452, 1431, 1358, 1333, 1248, 1211, 1148, 1076, 1049, 976, 853, 806, 773, $746 \mathrm{~cm}^{-1} ;{ }^{1} \mathbf{H}$ NMR $\left(400 \mathrm{MHz}, \mathrm{CDCl}_{3}\right) \delta 5.03(\mathrm{AB} \mathrm{q}, \Delta v=11.1 \mathrm{~Hz}, J=12.7 \mathrm{~Hz}, 4 \mathrm{H}), 6.90-7.10(\mathrm{~m}, 10 \mathrm{H}), 7.27-7.45(\mathrm{~m}$, $12 \mathrm{H}), 7.51(\mathrm{ddd}, J=1.3,6.8,8.2 \mathrm{~Hz}, 2 \mathrm{H}), 7.77(\mathrm{~d}, J=8.8 \mathrm{~Hz}, 2 \mathrm{H}), 7.80-7.87(\mathrm{~m}, 10 \mathrm{H}), 8.02(\mathrm{~d}, J=$ $8.2 \mathrm{~Hz}, 2 \mathrm{H}), 8.12(\mathrm{~d}, J=8.9 \mathrm{~Hz}, 2 \mathrm{H}), 8.69(\mathrm{~d}, J=9.3 \mathrm{~Hz}, 2 \mathrm{H}) ;{ }^{13} \mathbf{C} \mathbf{~ N M R}\left(100 \mathrm{MHz}, \mathrm{CDCl}_{3}\right) \delta 71.3$, 115.8, 119.2, 122.5, 124.1, 124.26, 124.30, 125.3, 125.8, 125.9, 126.0, 126.6, 126.7, 126.86, 126.90, 127.0, 127.1, 127.7, 128.2, 128.5, 128.7, 129.0, 129.4, 129.5, 130.3, 130.9, 132.2, 133.4, 134.2, 134.3, 137.6, 147.6, 154.4, 166.2; HR MS (ESI ${ }^{+}$) Calcd for $\mathrm{C}_{72} \mathrm{H}_{46} \mathrm{O}_{6} \mathrm{Na}: 1029.3163[\mathrm{M}+\mathrm{Na}]^{+}$. Found: 1029.3187.

\section{Synthesis of 19}

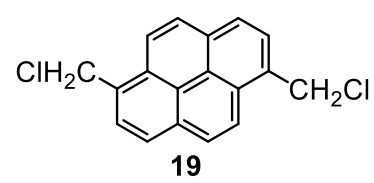

To a solution of 1,6-dibromopyrene (21) $(474 \mathrm{mg}, 1.32 \mathrm{mmol})$ in benzene $(2.3 \mathrm{~mL})$ and $\mathrm{Et}_{2} \mathrm{O}(1.1$ $\mathrm{mL}), 1.6 \mathrm{M} \mathrm{n}$-BuLi in hexane $(3.3 \mathrm{~mL}, 5.3 \mathrm{mmol})$ was added dropwise at $-78{ }^{\circ} \mathrm{C}$ under $\mathrm{N}_{2}$ atmosphere. The solution was stirred at $0{ }^{\circ} \mathrm{C}$ for $1 \mathrm{~h}$. A solution of paraformaldehyde $(500 \mathrm{mg})$ in $\mathrm{Et}_{2} \mathrm{O}(2.0 \mathrm{~mL})$ was added to the solution at $-78{ }^{\circ} \mathrm{C}$, and the reaction mixture was stirred at room temperature for $16 \mathrm{~h}$. The reaction was quenched with $1 \mathrm{M} \mathrm{HCl}$ aq., and the organic solvent was evaporated in vacuo to give a residue. The residue was washed with $\mathrm{H}_{2} \mathrm{O}$ and hexane and dried to give a crude 1,6-di(hydroxymethyl)pyrene $(239 \mathrm{mg}$ ) as a yellow powder. To a solution of the crude 1,6-di(hydroxymethyl)pyrene in $\mathrm{CH}_{2} \mathrm{Cl}_{2}(7.5 \mathrm{~mL})$ and pyridine $(0.3 \mathrm{~mL}), \mathrm{SOCl}_{2}(0.65 \mathrm{~mL}, 8.9$ mmol) was added dropwise at room temperature under $\mathrm{N}_{2}$ atmosphere. The reaction mixture was stirred at room temperature for $18 \mathrm{~h}$. The reaction was quenched with $\mathrm{H}_{2} \mathrm{O}$, and the organic solvent 
was evaporated in vacuo to give a residue. The residue was washed with hexane and $\mathrm{H}_{2} \mathrm{O}$ and dried to afford 19 (143 $\mathrm{mg}, 478 \mu \mathrm{mol}, 40 \%)$ as a yellow powder.

mp $210{ }^{\circ} \mathrm{C}$ (dec.); IR (KBr) 3051, 2978, 1907, 1452, 1385, 1314, 1258, 1246, 847, 779, $719 \mathrm{~cm}^{-1}$; ${ }^{1} \mathbf{H}$ NMR $\left(400 \mathrm{MHz}, \mathrm{CDCl}_{3}\right) \delta 5.33(\mathrm{~s}, 4 \mathrm{H}), 8.06(\mathrm{~d}, J=7.8 \mathrm{~Hz}, 2 \mathrm{H}), 8.19(\mathrm{~d}, J=9.2 \mathrm{~Hz}, 2 \mathrm{H}), 8.20$ $(\mathrm{d}, J=7.7 \mathrm{~Hz}, 2 \mathrm{H}), 8.41(\mathrm{~d}, J=9.3 \mathrm{~Hz}, 2 \mathrm{H}) ;{ }^{13} \mathbf{C}$ NMR $\left(100 \mathrm{MHz}, \mathrm{DMSO}-d_{6}\right) \delta 45.5,124.6,125.0$,

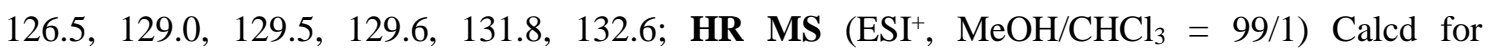
$\mathrm{C}_{20} \mathrm{H}_{18} \mathrm{O}_{2} \mathrm{Na}: 313.1199\left[\mathrm{M}-2 \mathrm{Cl}+2\left(\mathrm{OCH}_{3}\right)+\mathrm{Na}\right]^{+}$(methoxy substitution). Found: 313.1169 .

\section{Synthesis of $(R, R)-9$}

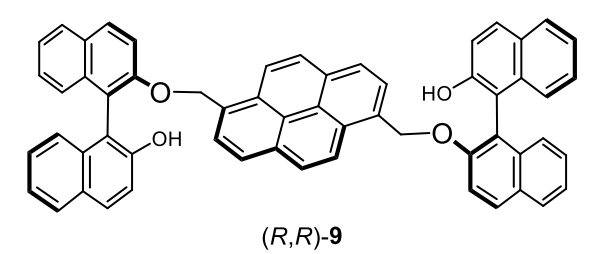

A mixture of $(R)$-BINOL (11) (240 mg, $838 \mu \mathrm{mol}), 1,6$-bis(chloromethyl)pyrene (19) (49.5 mg, $166 \mu \mathrm{mol})$, and $\mathrm{K}_{2} \mathrm{CO}_{3}(348 \mathrm{mg}, 2.52 \mathrm{mmol})$ in dry DMF $(4.1 \mathrm{~mL})$ was stirred at $60{ }^{\circ} \mathrm{C}$ for $19 \mathrm{~h}$ under $\mathrm{N}_{2}$ atmosphere. The reaction was quenched with water, and the product was extracted with $\mathrm{CHCl}_{3}$ (twice). The organic layer was washed successively with water (twice) and brine. After dried over $\mathrm{Na}_{2} \mathrm{SO}_{4}$, the solvent was evaporated in vacuo to give a residue. The residue was purified by column chromatography $\left(\mathrm{SiO}_{2}, \mathrm{CHCl}_{3} / \mathrm{EtOAc}=9 / 1\right)$ and $\mathrm{GPC}\left(\mathrm{CHCl}_{3}\right)$ to afford $(R, R)-\mathbf{9}(62.8 \mathrm{mg}$, $78.6 \mu \mathrm{mol}, 47 \%)$ as a yellow powder.

mp 77-80 ${ }^{\circ} \mathrm{C} ;[\alpha]_{\mathrm{D}}{ }^{27}=+527\left(\mathrm{CHCl}_{3}, c 0.10\right)$; IR $(\mathrm{KBr}) 3512,3059,1620,1506,1460,1431$, 1379, 1328, 1271, 1172, 1146, 1074, 1036, 974, 845, 814, $748 \mathrm{~cm}^{-1} ;{ }^{1} \mathbf{H} \mathbf{~ N M R}\left(400 \mathrm{MHz}, \mathrm{CDCl}_{3}\right) \delta$ $5.37(\mathrm{~s}, 2 \mathrm{H}), 6.03(\mathrm{AB} \mathrm{q}, \Delta v=28.7 \mathrm{~Hz}, J=9.9 \mathrm{~Hz}, 4 \mathrm{H}), 6.91(\mathrm{~d}, J=6.7 \mathrm{~Hz}, 2 \mathrm{H}), 6.93(\mathrm{t}, J=6.1 \mathrm{~Hz}$, 2H), $7.04(\mathrm{t}, J=9.6 \mathrm{~Hz}, 2 \mathrm{H}), 7.17(\mathrm{~d}, J=6.7 \mathrm{~Hz}, 2 \mathrm{H}), 7.20-7.28(\mathrm{~m}, 4 \mathrm{H}), 7.34(\mathrm{t}, J=6.0 \mathrm{~Hz}, 2 \mathrm{H})$, $7.53(\mathrm{~d}, J=6.2 \mathrm{~Hz}, 2 \mathrm{H}), 7.54(\mathrm{~d}, J=7.3 \mathrm{~Hz}, 2 \mathrm{H}), 7.57(\mathrm{~d}, J=7.3 \mathrm{~Hz}, 2 \mathrm{H}), 7.60(\mathrm{~d}, J=6.2 \mathrm{~Hz}, 2 \mathrm{H})$, $7.66(\mathrm{~d}, J=7.1 \mathrm{~Hz}, 2 \mathrm{H}), 7.69(\mathrm{~d}, J=7.3 \mathrm{~Hz}, 2 \mathrm{H}), 7.74(\mathrm{t}, J=6.5 \mathrm{~Hz}, 4 \mathrm{H}), 7.85(\mathrm{~d}, J=7.2 \mathrm{~Hz}, 2 \mathrm{H})$; ${ }^{13} \mathrm{C}$ NMR $\left(100 \mathrm{MHz}, \mathrm{CDCl}_{3}\right) \delta 71.1,115.2,117.2,117.6,118.2,122.7,123.1,124.4,124.5,124.7$, $125.4,126.3,126.5,127.3,127.5,127.8,128.2,129.1,129.8,129.9,130.1,130.9,131.0,133.9$, 134.2, 151.5, 155.1; HR MS $\left(\mathrm{ESI}^{+}\right)$Calcd for $\mathrm{C}_{58} \mathrm{H}_{38} \mathrm{O}_{4} \mathrm{Na}: 821.2662[\mathrm{M}+\mathrm{Na}]^{+}$. Found: 821.2650. 


\section{Synthesis of $(R)-10$}

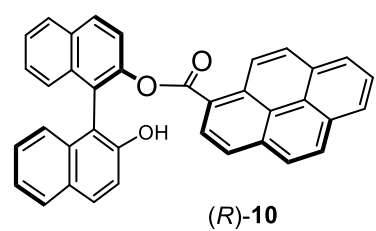

A solution of (R)-BINOL (11) (106 mg, $370 \mu \mathrm{mol})$, pyrene-1-carboxylic acid (20) $(86.0 \mathrm{mg}, 355$ $\mu \mathrm{mol}), \mathrm{EDC} \cdot \mathrm{HCl}(218 \mathrm{mg}, 1.14 \mathrm{mmol})$, and DMAP (124 mg, $1.01 \mathrm{mmol})$ in dry DMF (10 mL) was stirred at $40{ }^{\circ} \mathrm{C}$ for $22 \mathrm{~h}$. The reaction was quenched with water, and the product was extracted with $\mathrm{CHCl}_{3}$ (twice). The organic layer was washed successively with water (three times) and brine. After dried over $\mathrm{Na}_{2} \mathrm{SO}_{4}$, the solvent was evaporated to give a residue. The residue was purified by column chromatography $\left(\mathrm{SiO}_{2}, \mathrm{CHCl}_{3}\right)$ to afford $(R)-\mathbf{1 0}(69.4 \mathrm{mg}, 135 \mu \mathrm{mol}, 38 \%)$ as a yellow powder.

mp $113-118{ }^{\circ} \mathrm{C} ;[\alpha]_{D^{27}}=+301\left(\mathrm{CHCl}_{3}, c\right.$ 0.11); IR $(\mathrm{KBr}) 3433,3053,1727,1688,1624,1508$, 1433, 1383, 1346, 1250, 1211, 1144, 1080, 1032, 976, 849, 816, 749, $710 \mathrm{~cm}^{-1} ;{ }^{1} \mathbf{H}$ NMR $(400 \mathrm{MHz}$, $\left.\mathrm{CDCl}_{3}\right) \delta 5.41(\mathrm{~s}, 1 \mathrm{H}), 7.20-7.30(\mathrm{~m}, 2 \mathrm{H}), 7.32-7.38(\mathrm{~m}, 2 \mathrm{H}), 7.40-7.43(\mathrm{~m}, 2 \mathrm{H}), 7.54-7.60(\mathrm{~m}, 1 \mathrm{H})$, $7.70(\mathrm{~d}, J=9.0 \mathrm{~Hz}, 1 \mathrm{H}), 7.77-7.83(\mathrm{~m}, 2 \mathrm{H}), 7.89$ (d, $J=8.2 \mathrm{~Hz}, 1 \mathrm{H}), 7.95-8.08$ (m, 5H), 8.13 (d, $J$ $=8.8 \mathrm{~Hz}, 1 \mathrm{H}), 8.15-8.25(\mathrm{~m}, 3 \mathrm{H}), 8.75(\mathrm{~d}, J=9.5 \mathrm{~Hz}, 1 \mathrm{H}) ;{ }^{13} \mathbf{C} \mathbf{~ N M R}\left(100 \mathrm{MHz}, \mathrm{CDCl}_{3}\right) \delta 114.7$, 118.6, 122.37, 122.45, 123.7, 124.1, 124.3, 124.8, 124.9, 125.0, 126.1, 126.48, 126.51, 126.54, $127.0,127.2$, 127.7, 128.3, 128.6, 128.7, 129.5, 129.7, 130.1, 130.60, 130.63, 131.0, 131.2, 131.6, 132.7, 134.0, 134.1, 134.9, 149.0, 152.3, 167.3; HR MS (ESI $\left.{ }^{+}\right)$Calcd for $\mathrm{C}_{37} \mathrm{H}_{22} \mathrm{O}_{3} \mathrm{Na}$ : $537.1461[\mathrm{M}$ $+\mathrm{H}]^{+}$. Found: 537.1439 . 


\section{UV-Vis, CD, FL, CPL, and ESI-MS spectra}
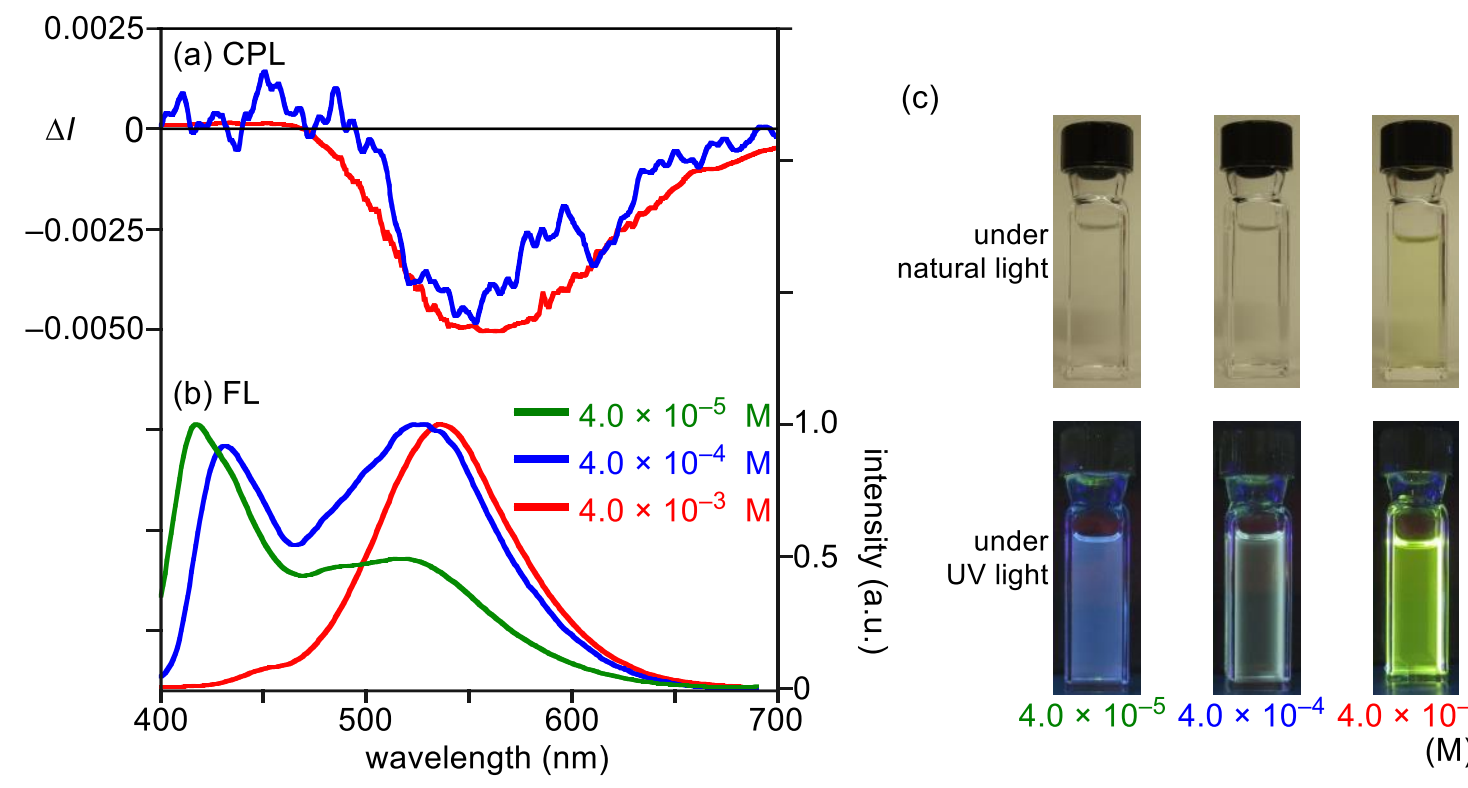

Figure S1. (a) CPL and (b) FL spectra of $(R, R)$-2. (c) Photographs of solutions of $(R, R)-2$. Conditions: $\mathrm{CH}_{2} \mathrm{Cl}_{2}, 20^{\circ} \mathrm{C}, l=1 \mathrm{~cm}, \lambda_{\mathrm{ex}}=355 \mathrm{~nm}$ for spectra and $365 \mathrm{~nm}$ for photographs. CPL spectrum of $4.0 \times 10^{-5} \mathrm{M}$ solution is omitted because of little or no signal.

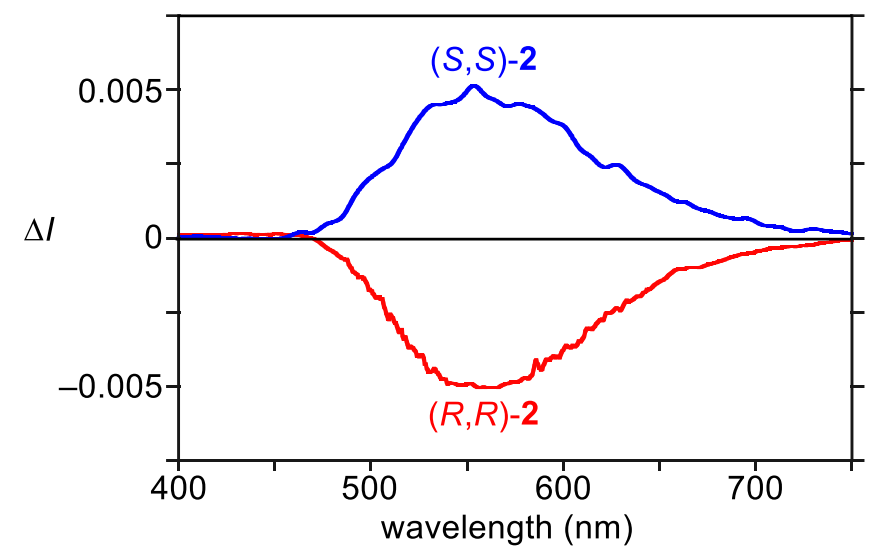

Figure S2. CPL spectra of $(R, R)-2$ and $(S, S)-2$. Conditions: $\mathrm{CH}_{2} \mathrm{Cl}_{2}, 4.0 \times 10^{-3} \mathrm{M}, 20^{\circ} \mathrm{C}, l=1 \mathrm{~cm}$, $\lambda_{\mathrm{ex}}=355 \mathrm{~nm}$. 


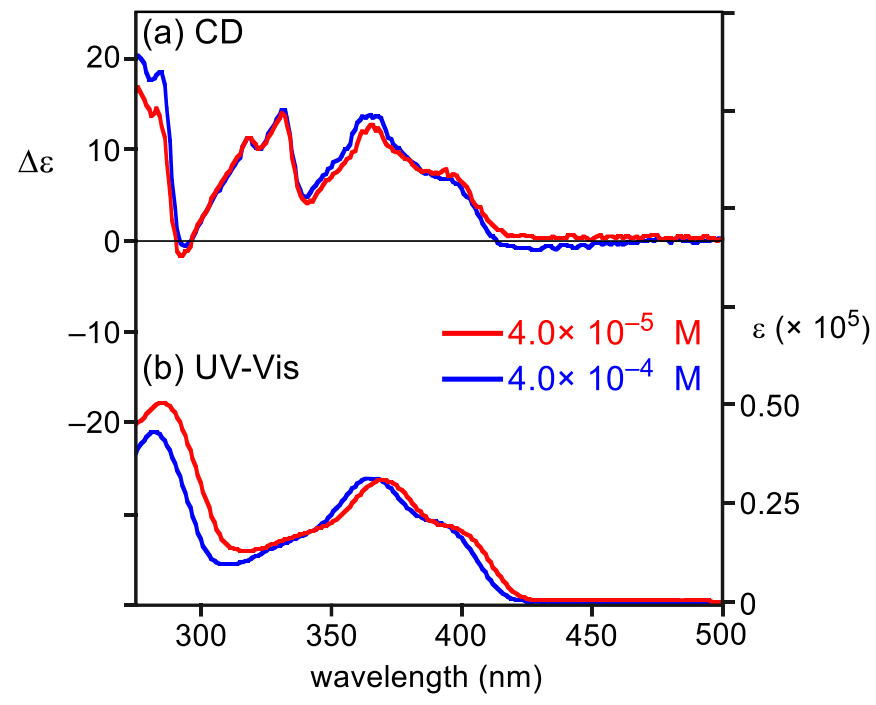

Figure S3. (a) $\mathrm{CD}$ and (b) UV-Vis spectra of $(R, R)$-2. Conditions: $\mathrm{CH}_{2} \mathrm{Cl}_{2}, 20{ }^{\circ} \mathrm{C}, l=1 \mathrm{~cm}$ for 4.0 $\times 10^{-5} \mathrm{M}$ and $0.1 \mathrm{~cm}$ for $4.0 \times 10^{-4} \mathrm{M}, \lambda_{\mathrm{ex}}=355 \mathrm{~nm}$.

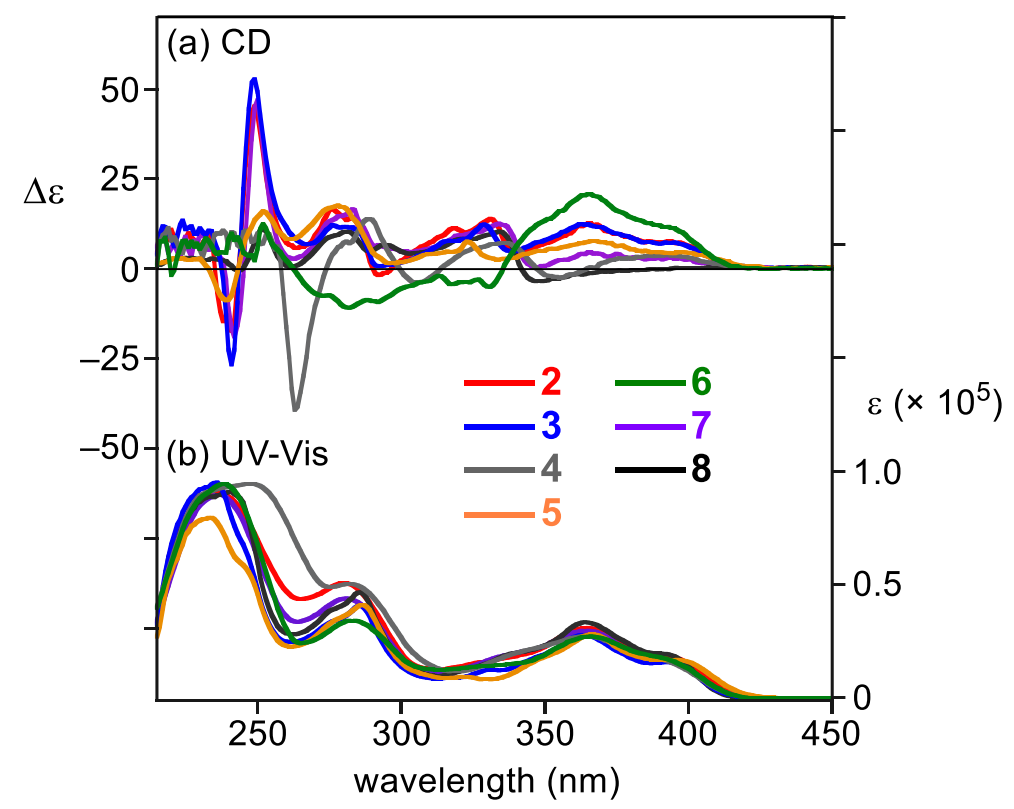

Figure S4. (a) CD and (b) UV-Vis spectra of $(R, R)-2-8$. Conditions: $\mathrm{CH}_{2} \mathrm{Cl}_{2}, 4.0 \times 10^{-4} \mathrm{M}, 20^{\circ} \mathrm{C}$, $l=0.1 \mathrm{~cm}$. 
(a)

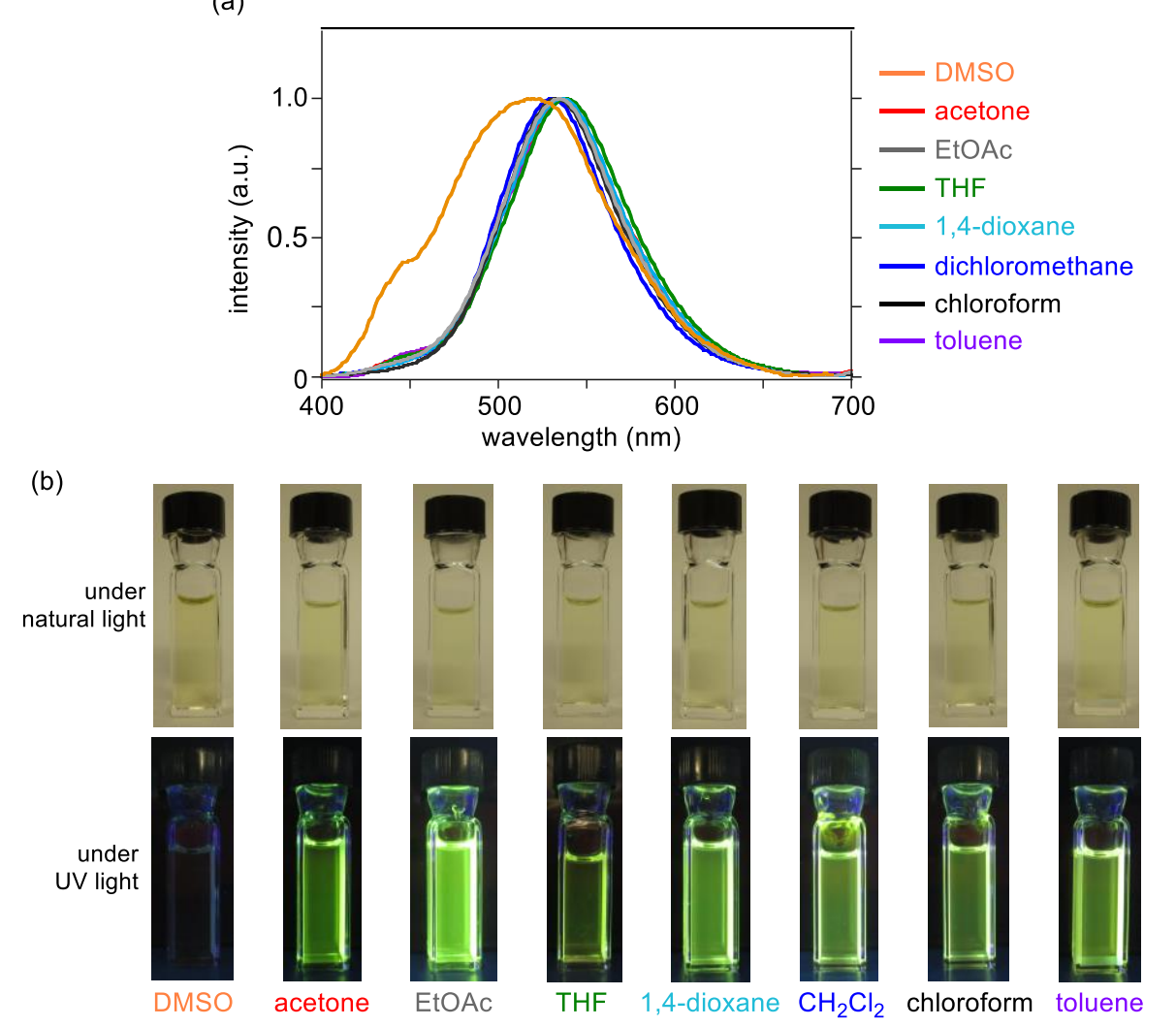

Figure S5. (a) FL spectra and (b) photographs of $(R, R)-3$. Conditions: $4.0 \times 10^{-3} \mathrm{M}, 20^{\circ} \mathrm{C}, l=1$ $\mathrm{cm}, \lambda_{\mathrm{ex}}=355 \mathrm{~nm}$ for spectra and $365 \mathrm{~nm}$ for photographs.

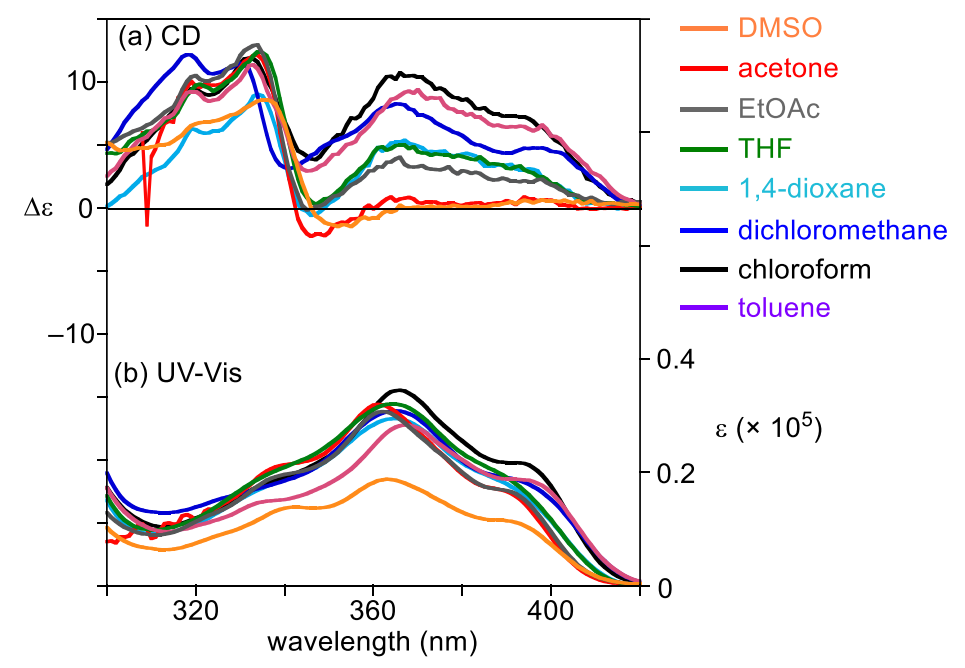

Figure S6. (a) CD and (b) UV-Vis spectra of $(R, R)-2$. Conditions: $4.0 \times 10^{-4} \mathrm{M}, 20{ }^{\circ} \mathrm{C}, l=0.1 \mathrm{~cm}$. 


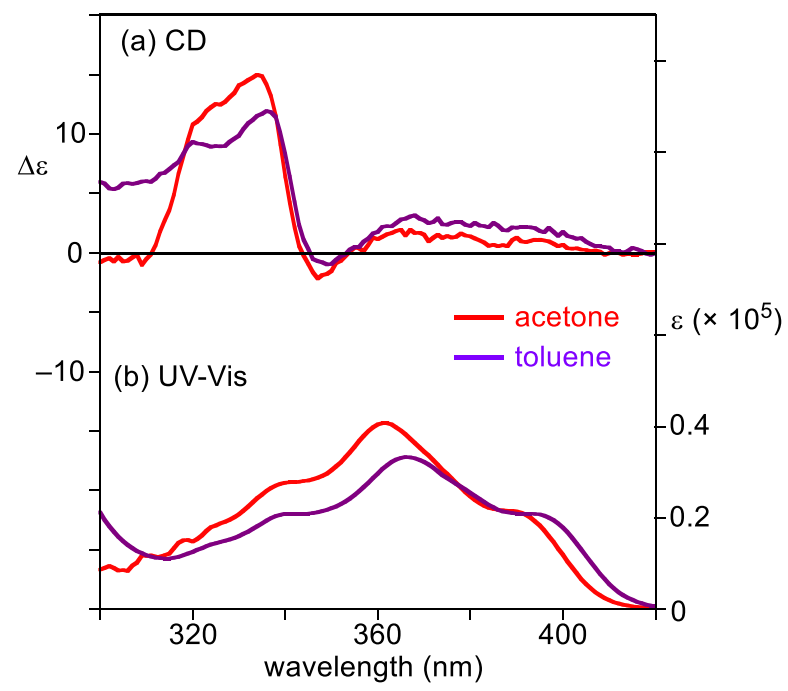

Figure S7. (a) CD and (b) UV-Vis spectra of $(R, R)-7$. Conditions: $4.0 \times 10^{-4} \mathrm{M}, 20^{\circ} \mathrm{C}, l=0.1 \mathrm{~cm}$.

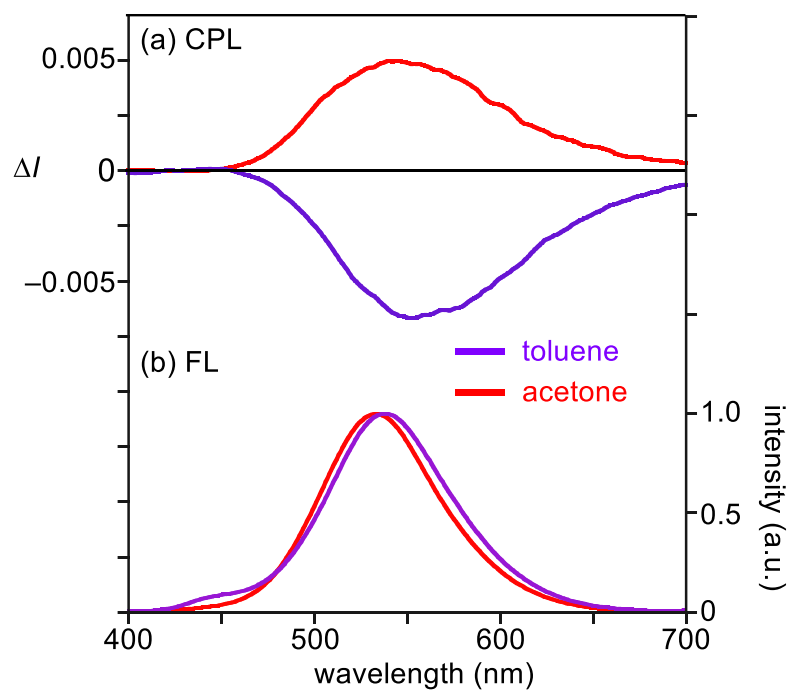

Figure S8. (a) CPL and (b) FL spectra of $(R, R)-2$. Conditions: $4.0 \times 10^{-3} \mathrm{M}, 20^{\circ} \mathrm{C}, l=1 \mathrm{~cm}, \lambda_{\mathrm{ex}}=$ $355 \mathrm{~nm}$. 


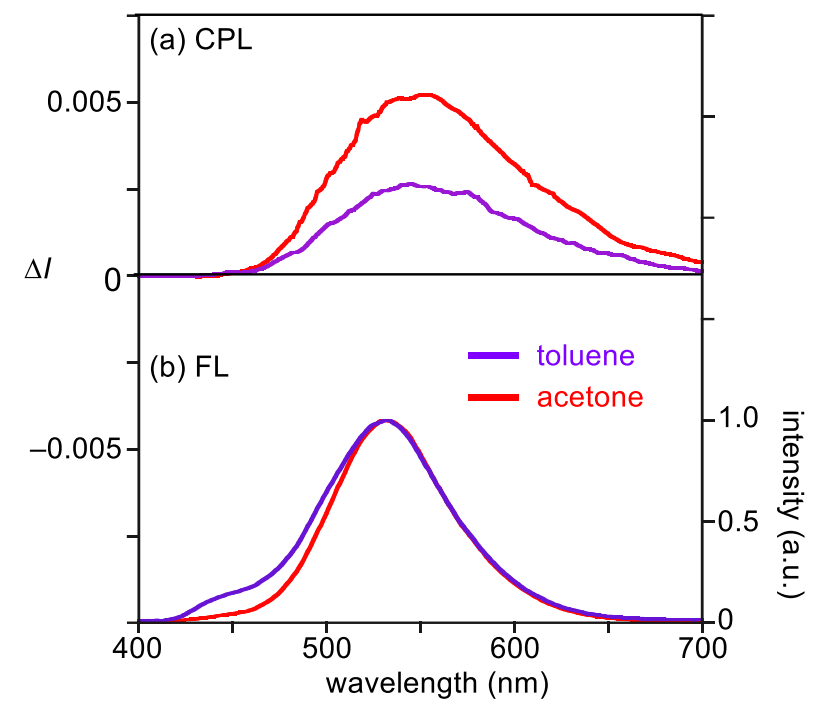

Figure S9. (a) CPL and (b) FL spectra of $(R, R)-7$. Conditions: $4.0 \times 10^{-3} \mathrm{M}, 20^{\circ} \mathrm{C}, l=1 \mathrm{~cm}, \lambda_{\text {ex }}=$ $355 \mathrm{~nm}$.
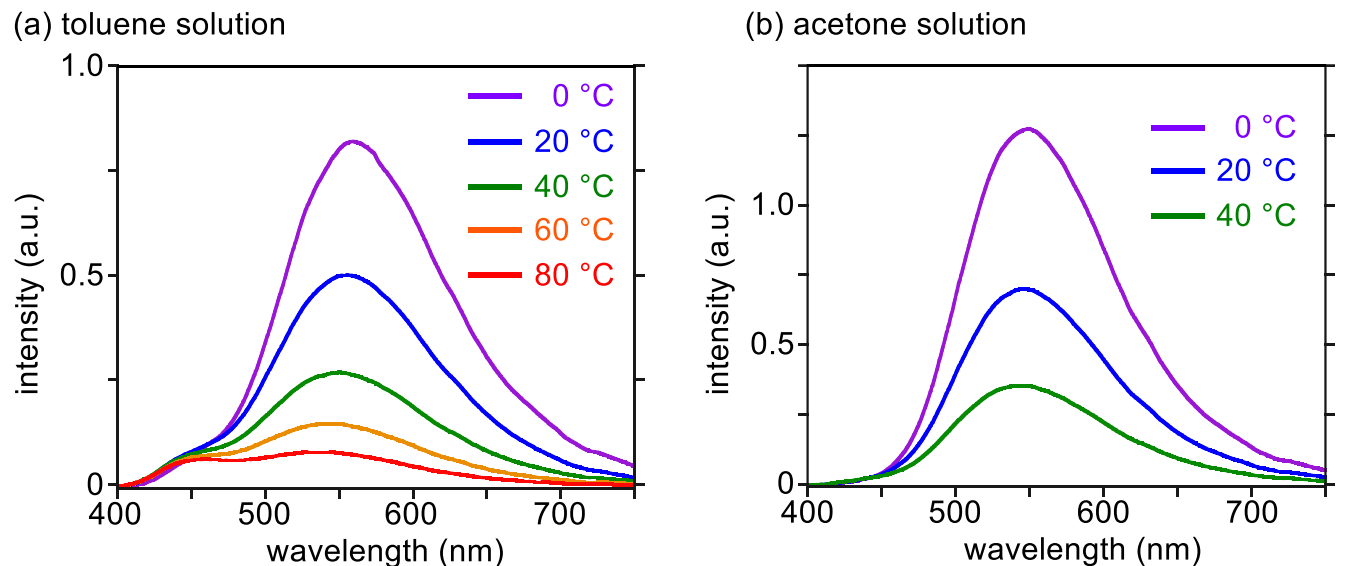

Figure S10. VT FL spectra of (a) toluene and (b) acetone solutions of $(R, R)-\mathbf{3}$. Conditions: toluene or acetone, $4.0 \times 10^{-3} \mathrm{M}, 20^{\circ} \mathrm{C}, l=1 \mathrm{~cm}, \lambda_{\mathrm{ex}}=355 \mathrm{~nm}$. 


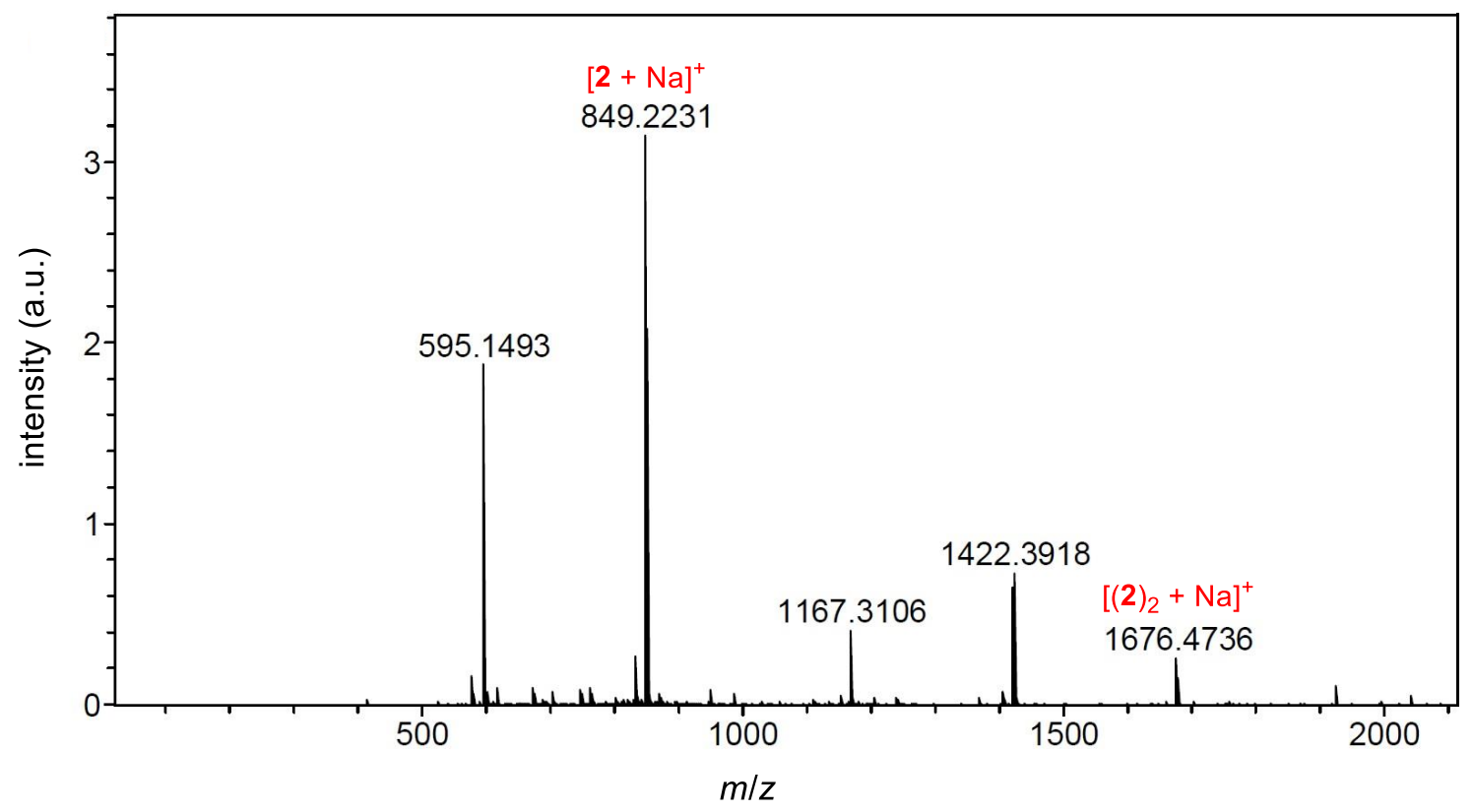

Figure S11. HR ESI-TOF-(+)-MS spectra of $(R, R)$-2 . 
We investigated the aggregation-induced (AI)-CPL character of $(R, R)-3$ in poor solvents (Figures S12-15). $(R, R)-3$ dissolved in mixtures of $1 \%$ THF and either $99 \%$ water or hexane exhibited intense excimer FL even under diluted conditions $\left(4.0 \times 10^{-5} \mathrm{M}\right)$ although a $100 \%$ THF solution showed weak excimer FL (Figures S13-14). The FL quantum yields, $\Phi_{\mathrm{FL}}$, are 0.37 for the $\mathrm{THF} / \mathrm{H}_{2} \mathrm{O}$ solution and 0.03 for the THF/hexane solution. The broad absorption at a longer wavelength (400-900 nm) supports the aggregation behavior (Figure S15). THF/ $\mathrm{H}_{2} \mathrm{O}$ and THF/hexane acted as polar and nonpolar solvents, respectively, and the former solution exhibited (+)-CPL with a $\left|g_{\text {lum }}\right|$ of $3.9 \times 10^{-3}$ and the latter solution exhibited (-)-CPL with a $\left|g_{\text {lum }}\right|$ of 0.010 .

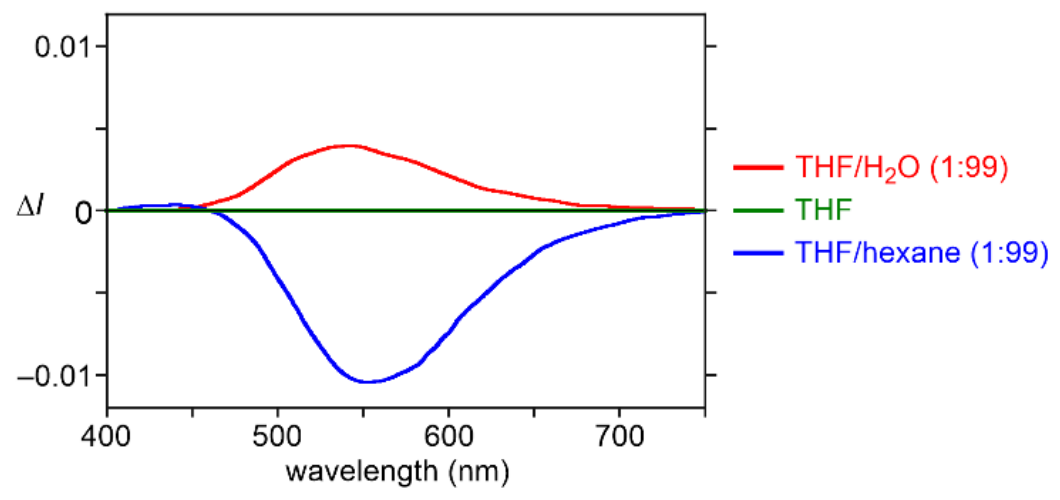

Figure S12. CPL spectra of $(R, R)-3$ in THF/ $\mathrm{H}_{2} \mathrm{O}$ (1:99), THF, and THF/hexane (1:99). Conditions: $4.0 \times 10^{-5} \mathrm{M}, 20^{\circ} \mathrm{C}, l=1 \mathrm{~cm}, \lambda_{\mathrm{ex}}=355 \mathrm{~nm}$.

(a)

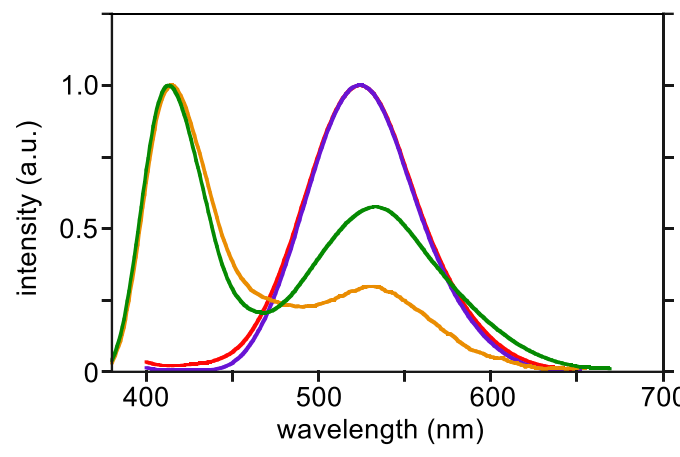

(b)

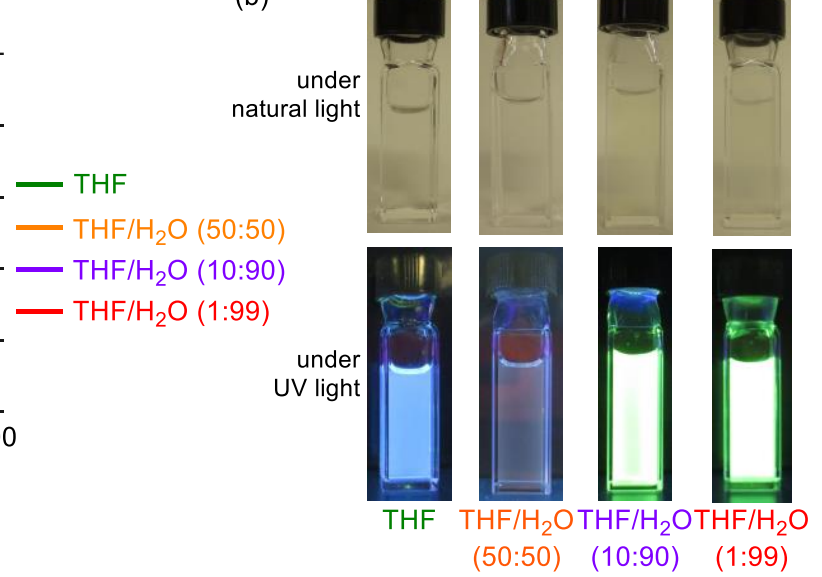

Figure S13. (a) FL spectra and (b) photographs of $\mathrm{THF} / \mathrm{H}_{2} \mathrm{O}$ solutions of $(R, R)-3$. Conditions: 4.0 $\times 10^{-5} \mathrm{M}, 20^{\circ} \mathrm{C}, l=1 \mathrm{~cm}, \lambda_{\mathrm{ex}}=355 \mathrm{~nm}$ for spectra and $365 \mathrm{~nm}$ for photographs. 
(a)

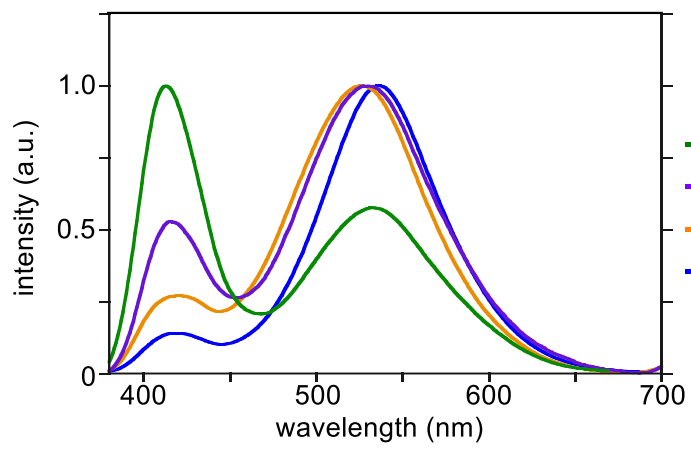

(b)

- THF

- THF/hexane (50:50)

- THF/hexane (10:90)

THF/hexane (1:99)
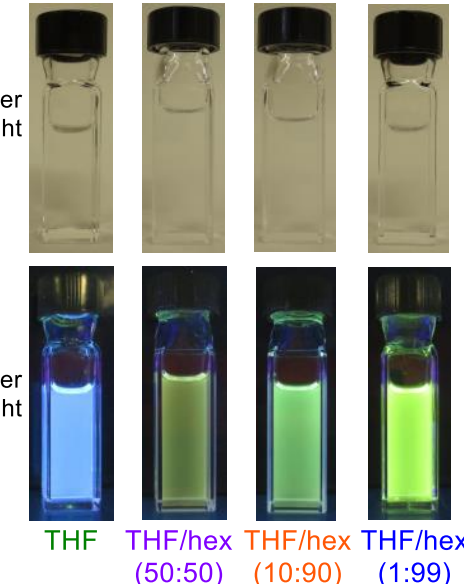

Figure S14. (a) FL spectra and (b) photographs of THF/hexane solutions of $(R, R)-3$. Conditions: $4.0 \times 10^{-5} \mathrm{M}, 20^{\circ} \mathrm{C}, l=1 \mathrm{~cm}, \lambda_{\mathrm{ex}}=355 \mathrm{~nm}$ for spectra and $365 \mathrm{~nm}$ for photographs.

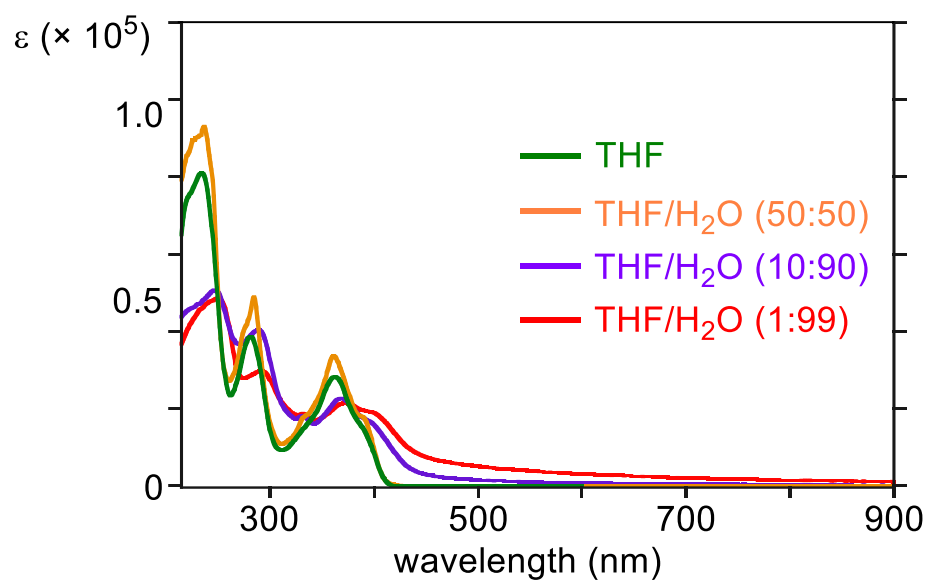

Figure S15. UV-Vis-NIR spectra of $\mathrm{THF} / \mathrm{H}_{2} \mathrm{O}$ solutions of $(R, R)-3$. Conditions: $4.0 \times 10^{-5} \mathrm{M}$, $20{ }^{\circ} \mathrm{C}, l=1 \mathrm{~cm}$. 


\section{DFT calculations}

The DFT calculations in this work were performed using Gaussian16, revision C.01. The excited state geometries were optimized at the B3LYP/6-31G(d,p) level in the gas phase.

(a) left-handed pyrene excimer $7_{\text {ex }} \mathrm{L}$
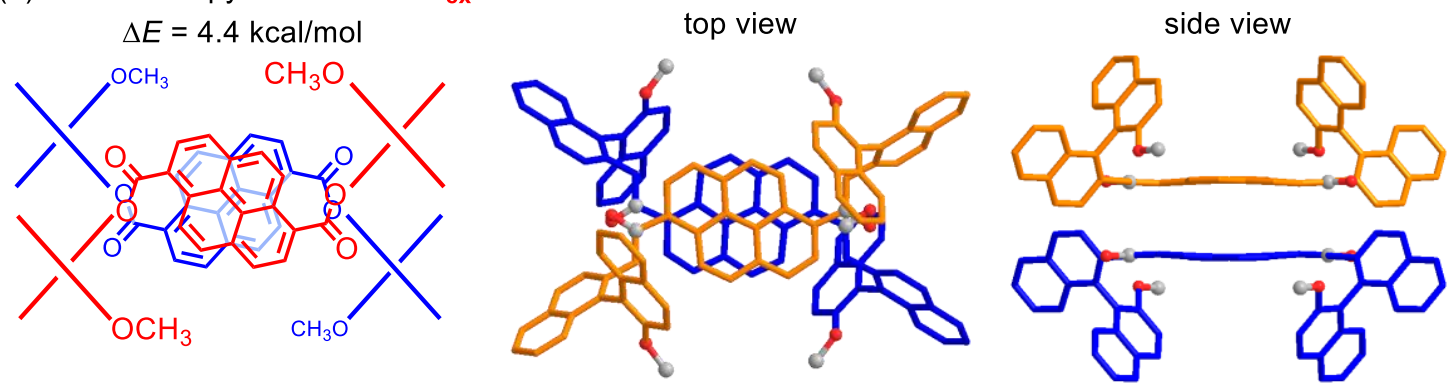

(b) right-handed pyrene excimer $7_{\text {ex }} \mathbf{R}$ $\Delta E=0 \mathrm{kcal} / \mathrm{mol}$
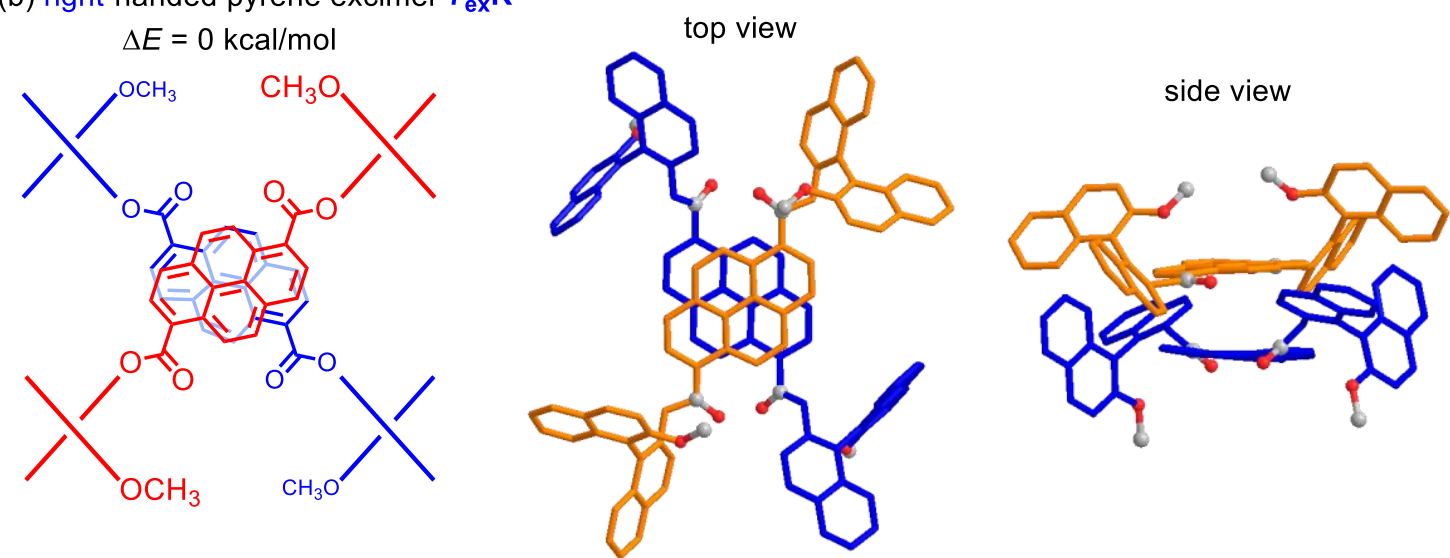

Figure S16. TD DFT-optimized excimers $7_{\mathrm{ex}} \mathbf{L}$ and $\mathbf{7}_{\mathrm{ex}} \mathbf{R}$ consisted of two molecules of $(R, R)-\mathbf{7}$ at the B3LYP/6-31G(d,p) level. Binaphthyls in chemical structures are shown in a cross frame. The distances between pyrene faces are fixed at $3.2 \AA$. 
(a) binaphthyl-pyrene dyad extracted from optimized $7_{\text {ex }}$ L $\Delta E=1.8 \mathrm{kcal} / \mathrm{mol}$
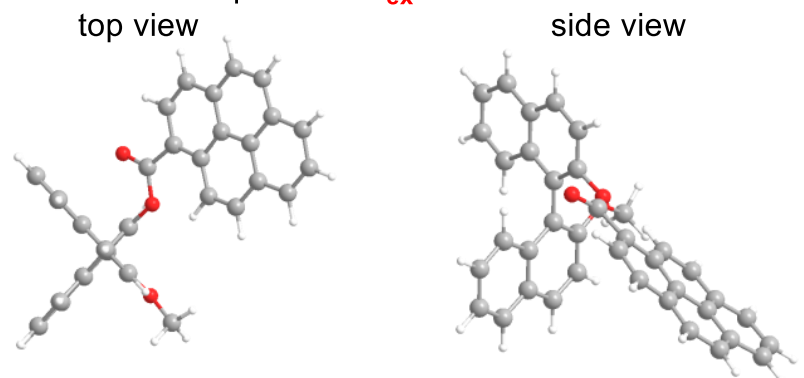

(b) binaphthyl-pyrene dyad extracted from optimized $7_{\text {ex }} \mathbf{R}$
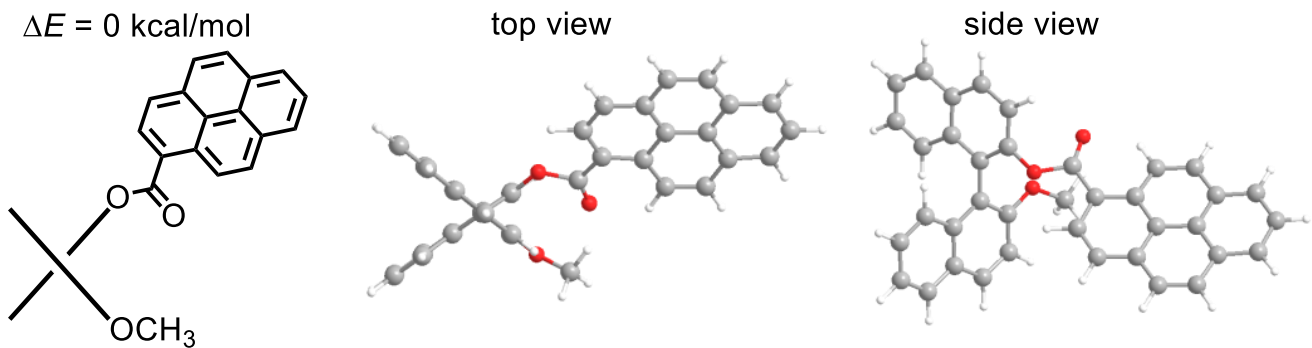

Figure S17. Structures of binaphthyl-pyrene dyads extracted from TD DFT-optimized $\mathbf{7}_{\mathbf{e x}} \mathbf{L}$ or $7_{\mathrm{ex}} \mathbf{R}$ at the B3LYP/6-31G(d,p) level. 


\section{5. ${ }^{1} \mathrm{H}$ NMR and ${ }^{13} \mathrm{C}$ NMR spectra}

(a) $4.0 \times 10^{-3} \mathrm{M}$ in $\mathrm{CD}_{2} \mathrm{Cl}_{2}$

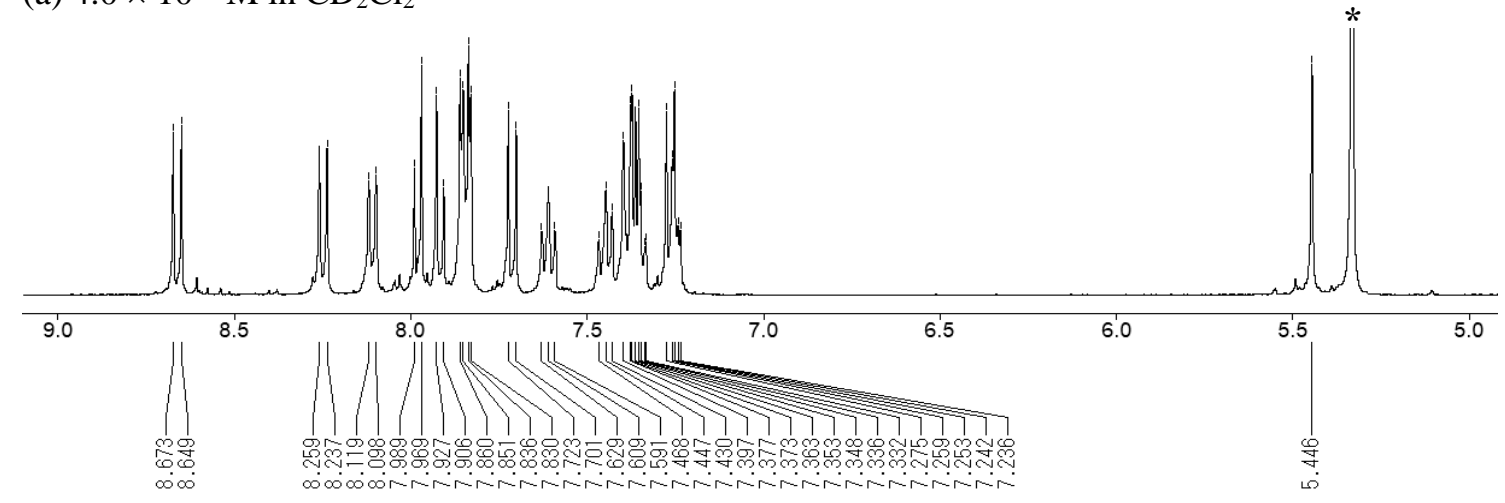

(b) $4.0 \times 10^{-4} \mathrm{M}$ in $\mathrm{CD}_{2} \mathrm{Cl}_{2}$

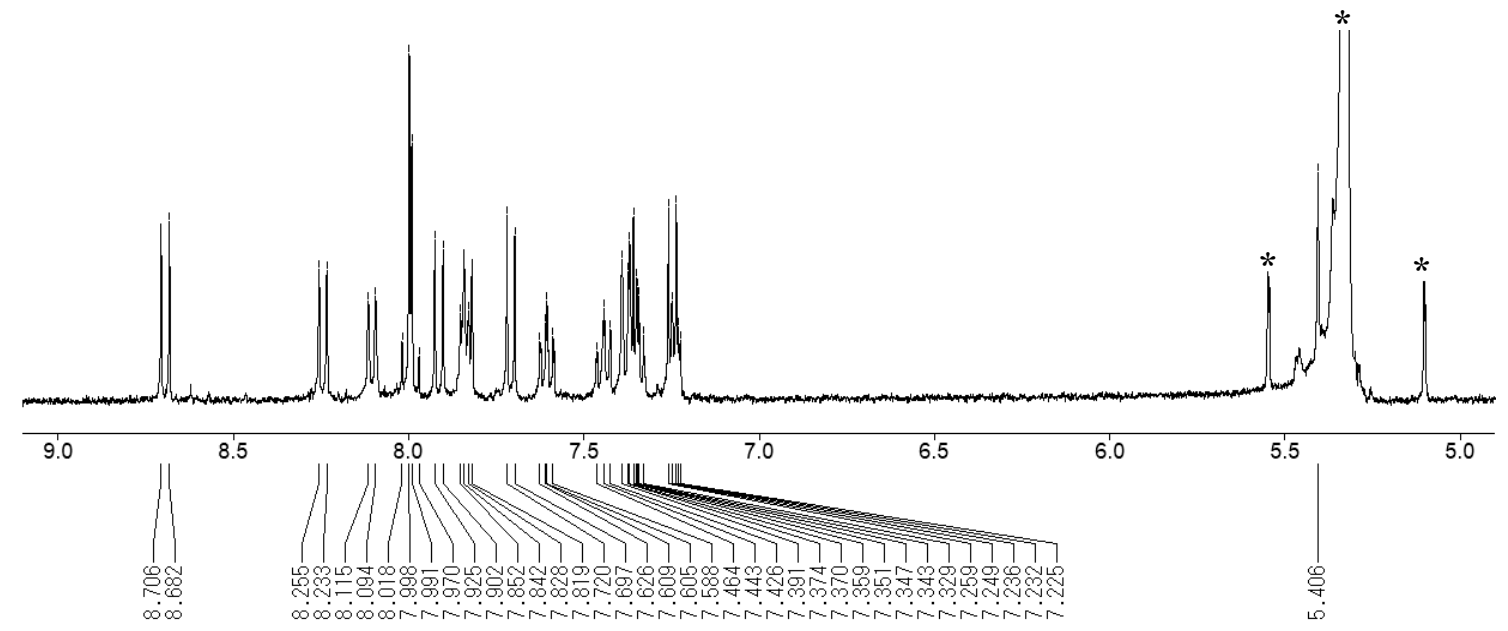

Figure S18. ${ }^{1} \mathrm{H}$ NMR spectra of $(R, R)-2$. Conditions: (a) $4.0 \times 10^{-3} \mathrm{M}$ or (b) $4.0 \times 10^{-4} \mathrm{M}, \mathrm{CD}_{2} \mathrm{Cl}_{2}$, $400 \mathrm{MHz}, 20^{\circ} \mathrm{C}$. 
(a) $4.0 \times 10^{-3} \mathrm{M}$ in $\mathrm{CD}_{2} \mathrm{Cl}_{2}$

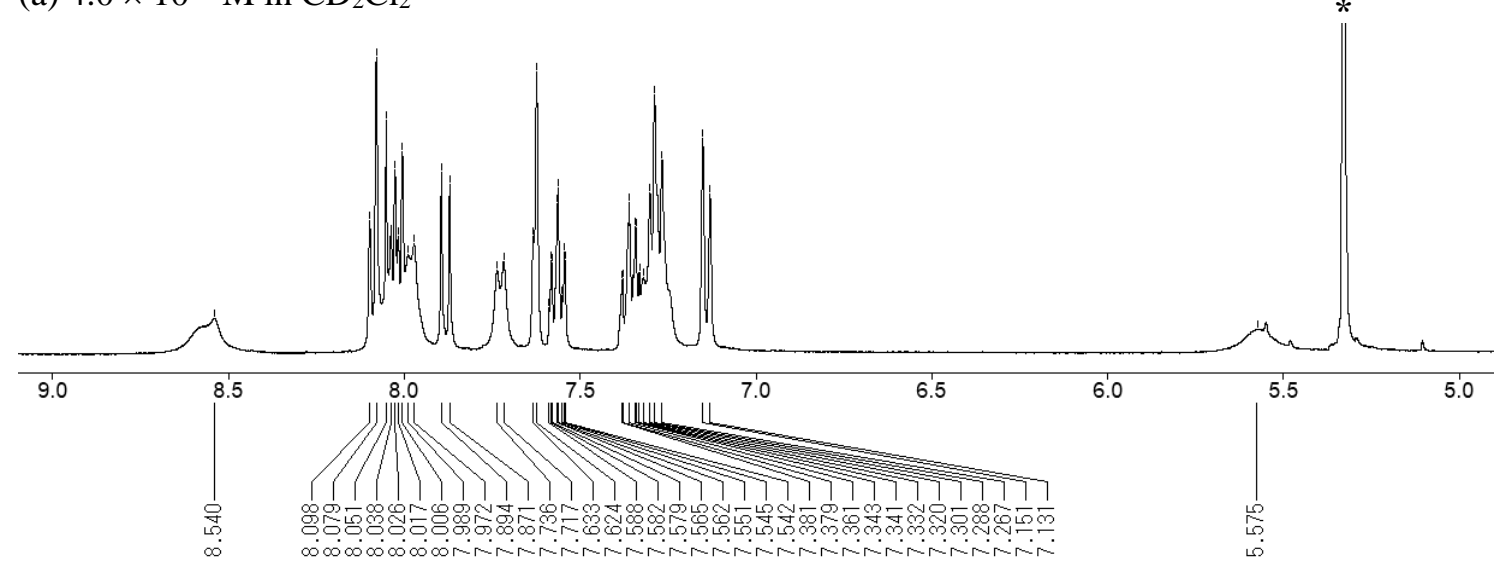

(b) $4.0 \times 10^{-4} \mathrm{M}$ in $\mathrm{CD}_{2} \mathrm{Cl}_{2}$

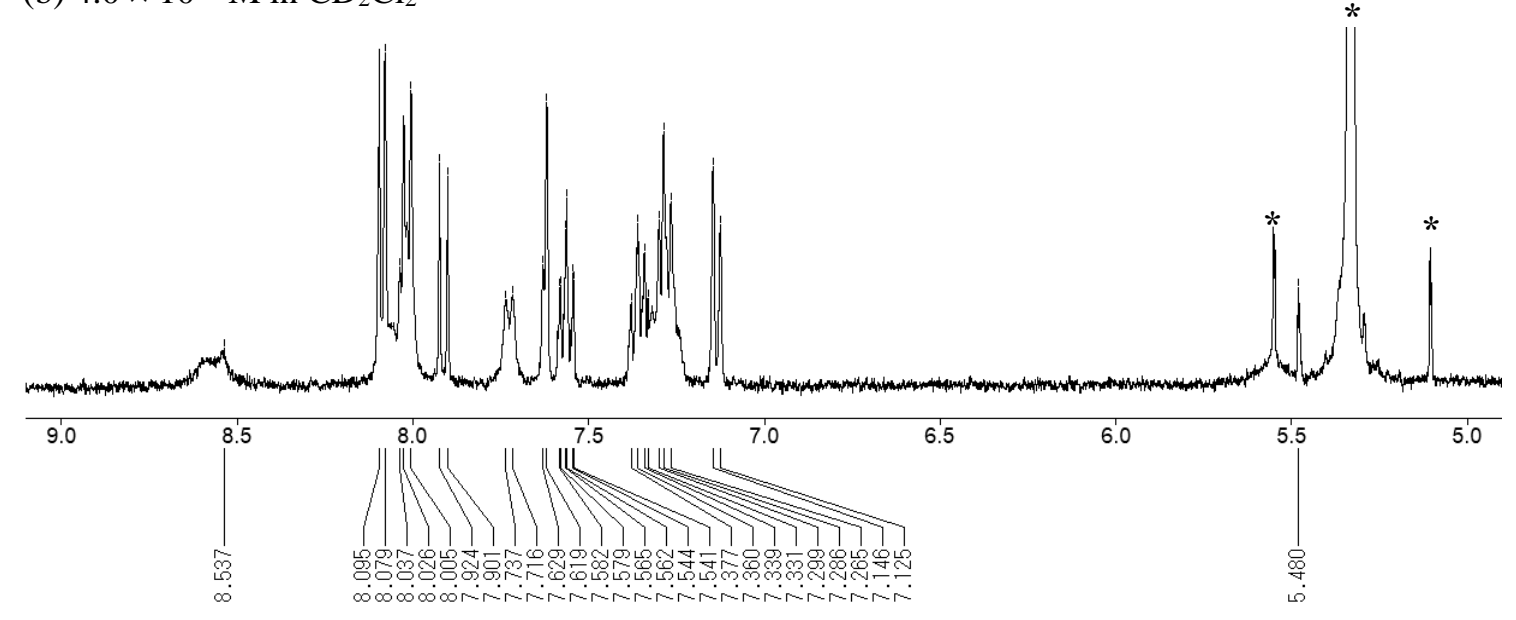

Figure S19. Partial ${ }^{1} \mathrm{H}$ NMR spectra of $(R, R)-3$. Conditions: (a) $4.0 \times 10^{-3} \mathrm{M}$ or (b) $4.0 \times 10^{-4} \mathrm{M}$, $\mathrm{CD}_{2} \mathrm{Cl}_{2}, 400 \mathrm{MHz}, 20^{\circ} \mathrm{C}$. $*$ Solvent peak. 
(a) $(R, R)-2$ in toluene- $d_{8}$.

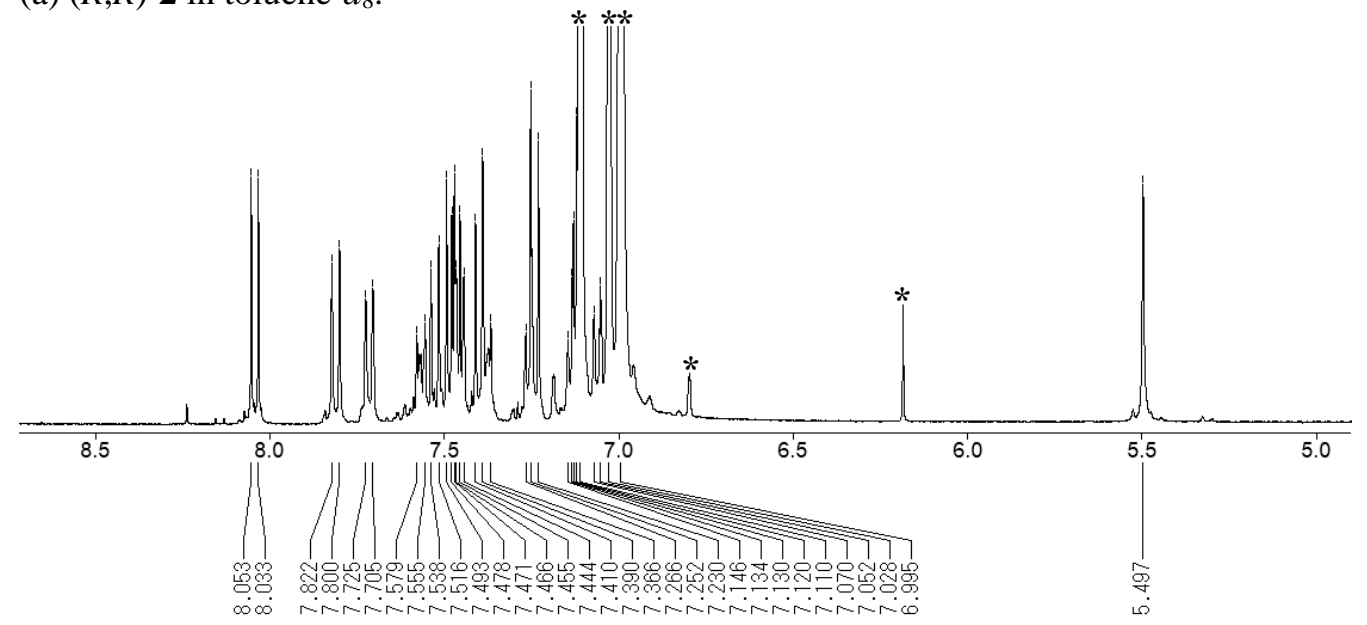

(b) $(R, R)-7$ in toluene- $d_{8}$.

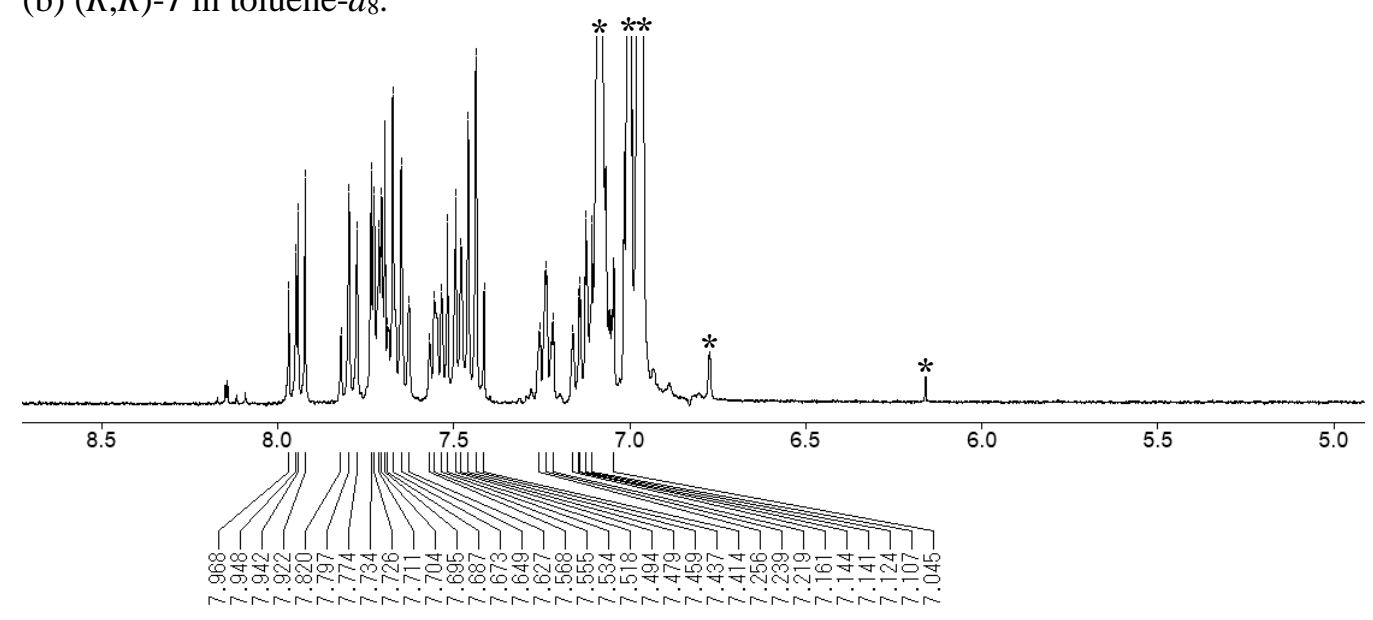

(c) $(R, R)-3$ in toluene- $d_{8}$.

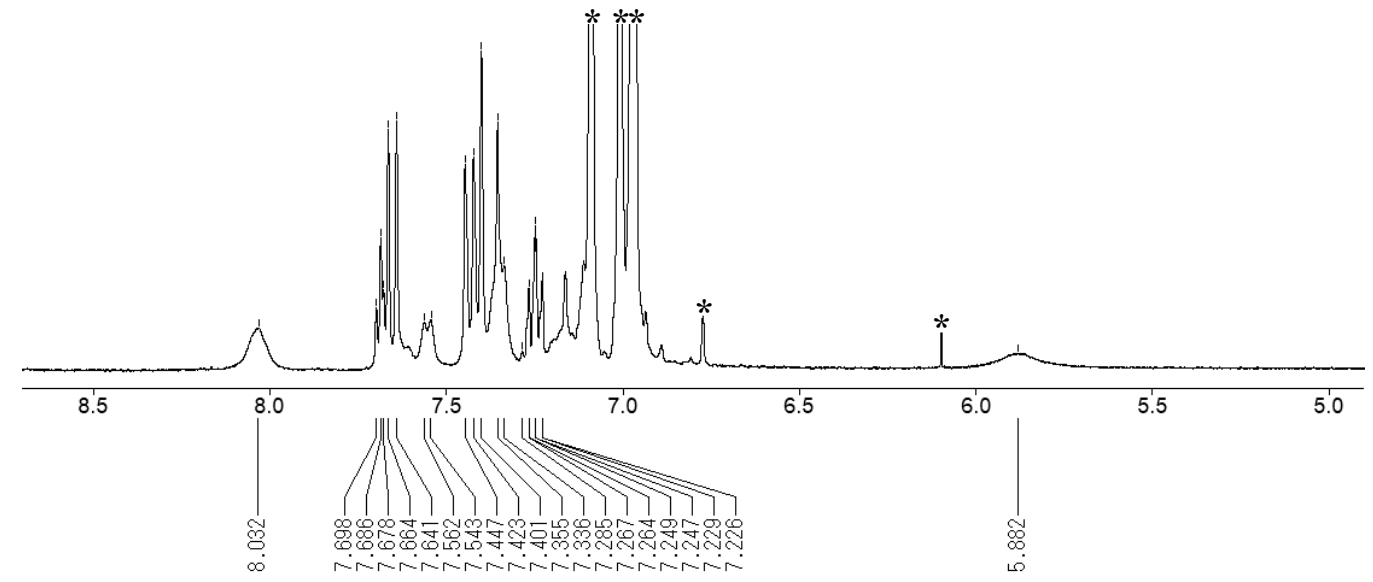

Figure S20. Partial ${ }^{1} \mathrm{H}$ NMR spectra of (a) $(R, R)-2$, (b) $(R, R)-\mathbf{7}$, and (c) $(R, R)-3$. Conditions: $4.0 \times$ $10^{-3} \mathrm{M}$, toluene- $d_{8}, 400 \mathrm{MHz}, 20{ }^{\circ} \mathrm{C}$. *Solvent peak (toluene and residual chloroform). 
(a) $(R, R)-\mathbf{2}$ in acetone- $d_{6}$.

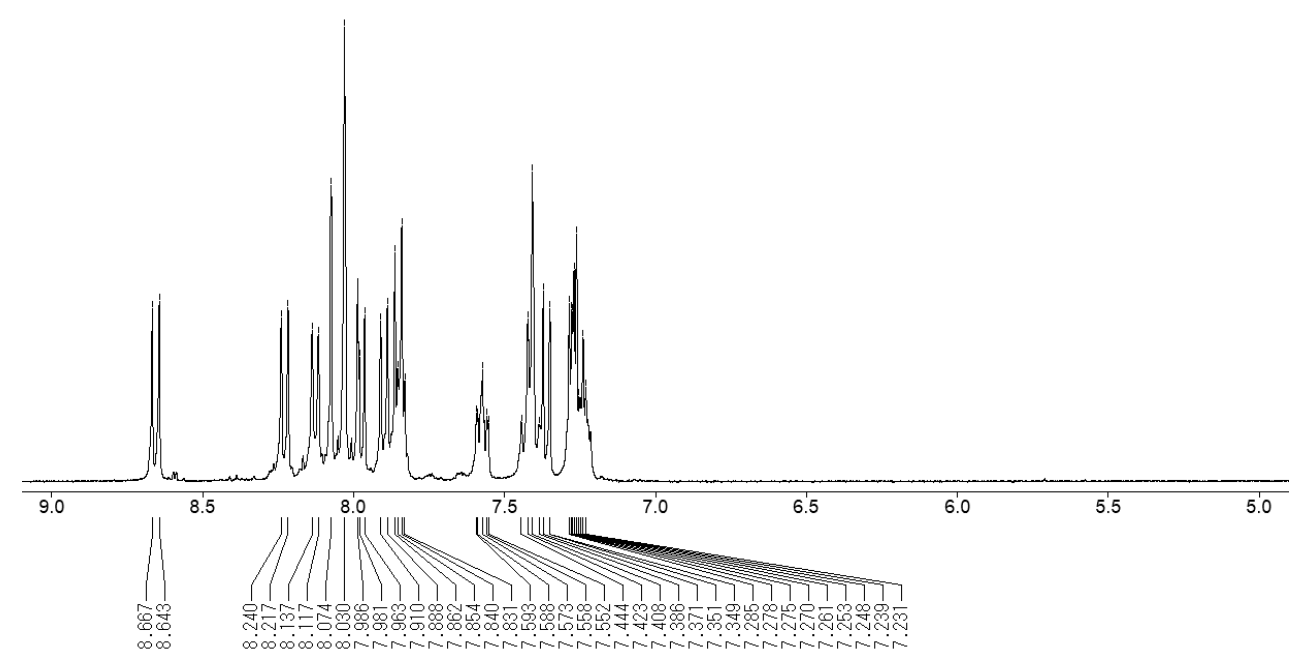

(b) $(R, R)-7$ in acetone- $d_{6}$.

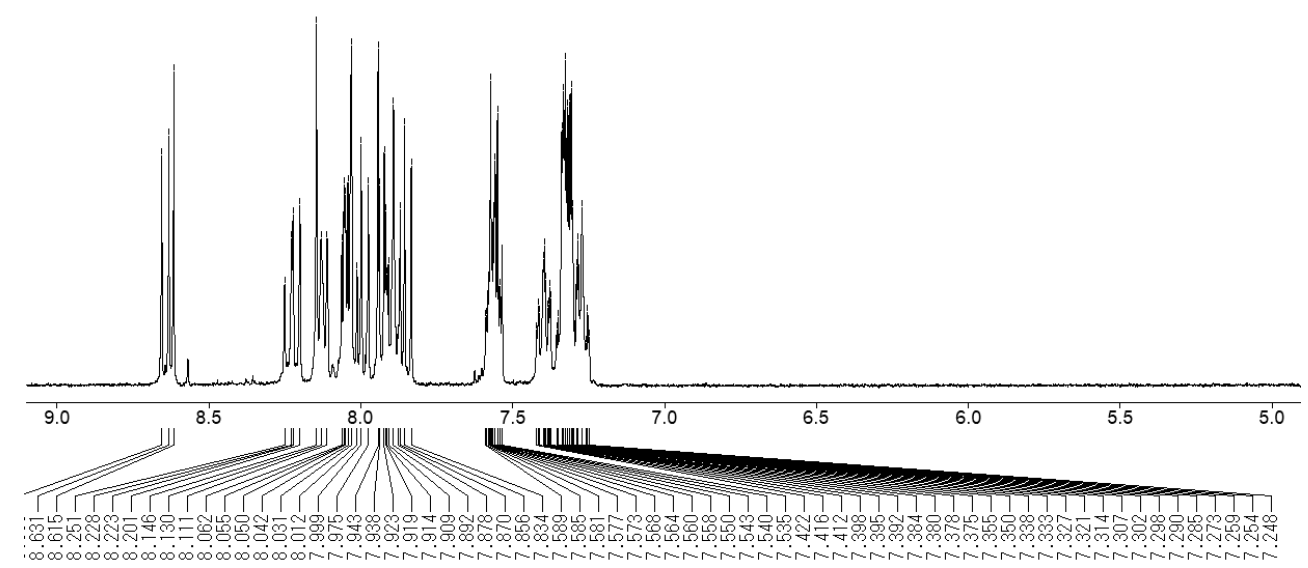

(c) $(R, R)-\mathbf{3}$ in acetone- $d_{6}$.

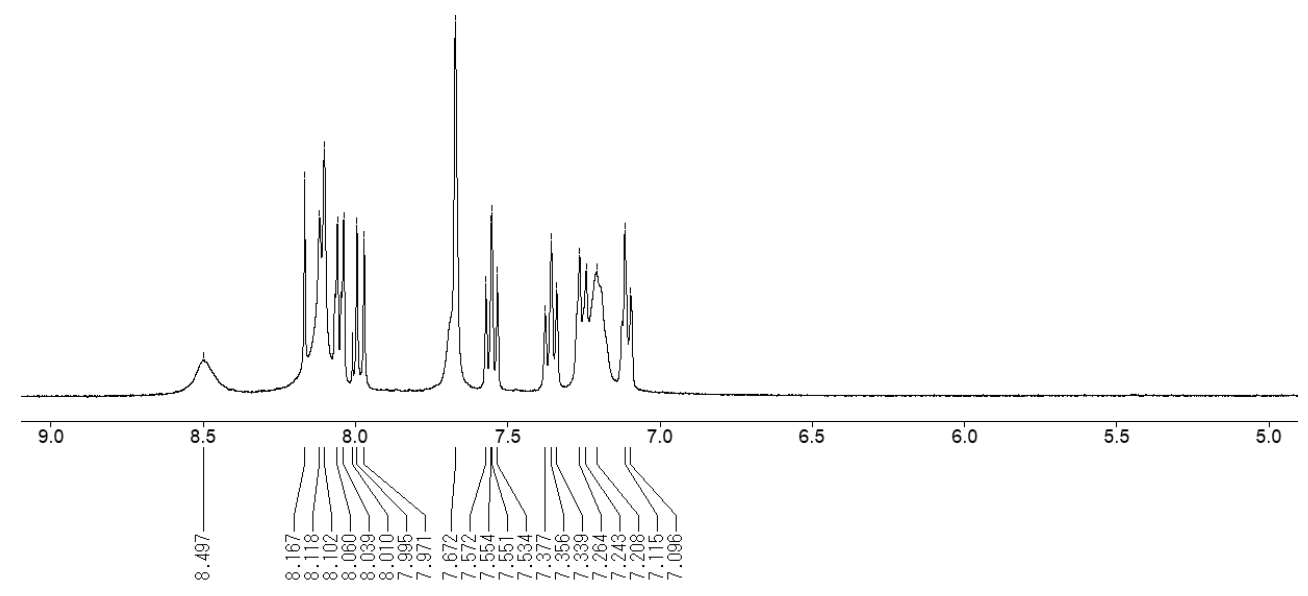

Figure S21. ${ }^{1} \mathrm{H}$ NMR spectra of (a) $(R, R)-2$, (b) $(R, R)-7$, and (c) $(R, R)-3$. Conditions: $4.0 \times 10^{-3} \mathrm{M}$, acetone- $d_{6}, 400 \mathrm{MHz}, 20^{\circ} \mathrm{C}$. 

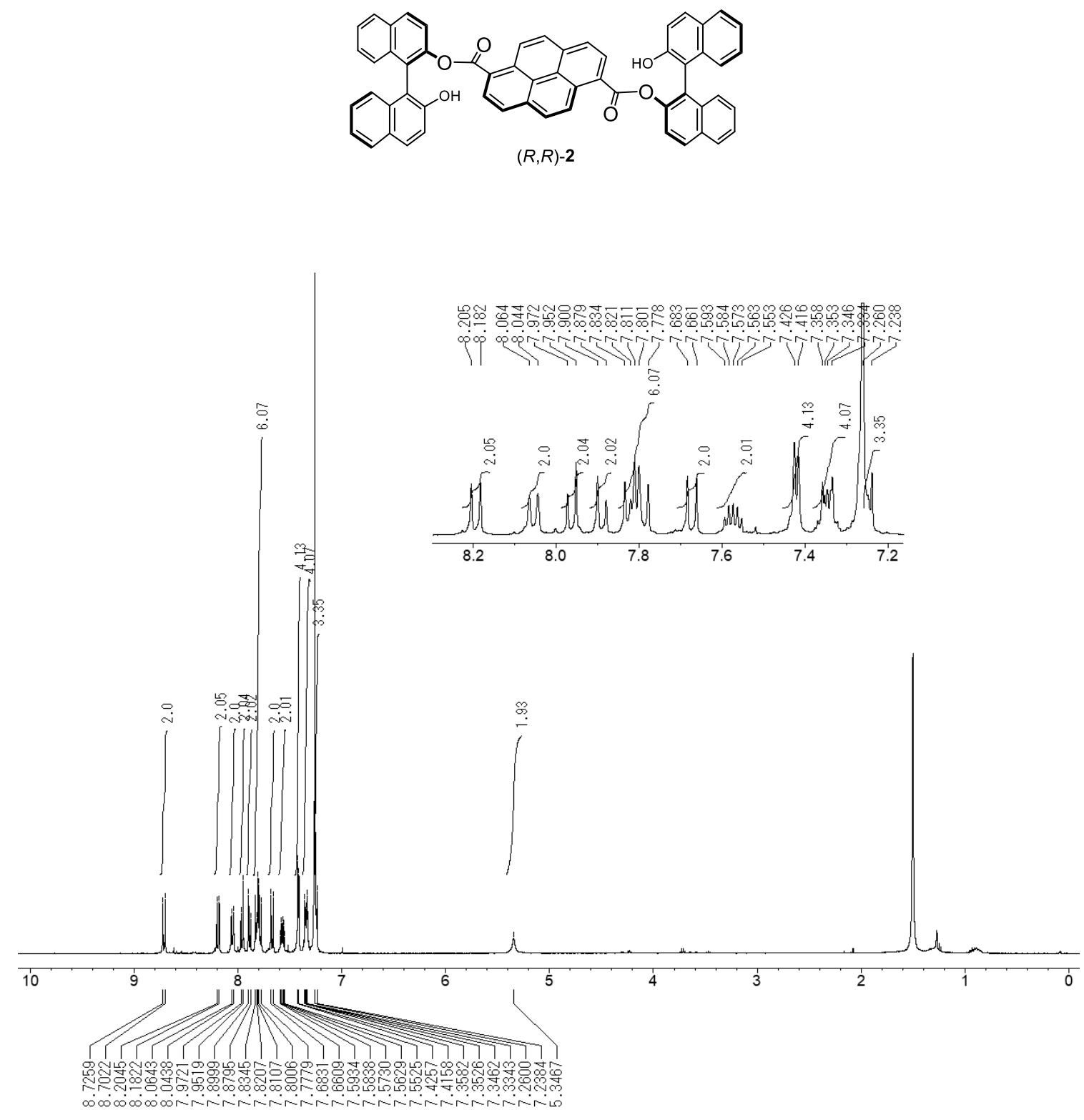

${ }^{1} \mathrm{H}$ NMR spectrum of $(R, R)-2\left(400 \mathrm{MHz}, \mathrm{CDCl}_{3}\right)$ 


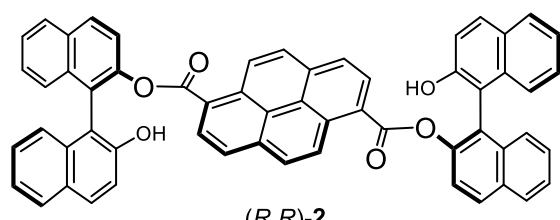

$(R, R)-\mathbf{2}$
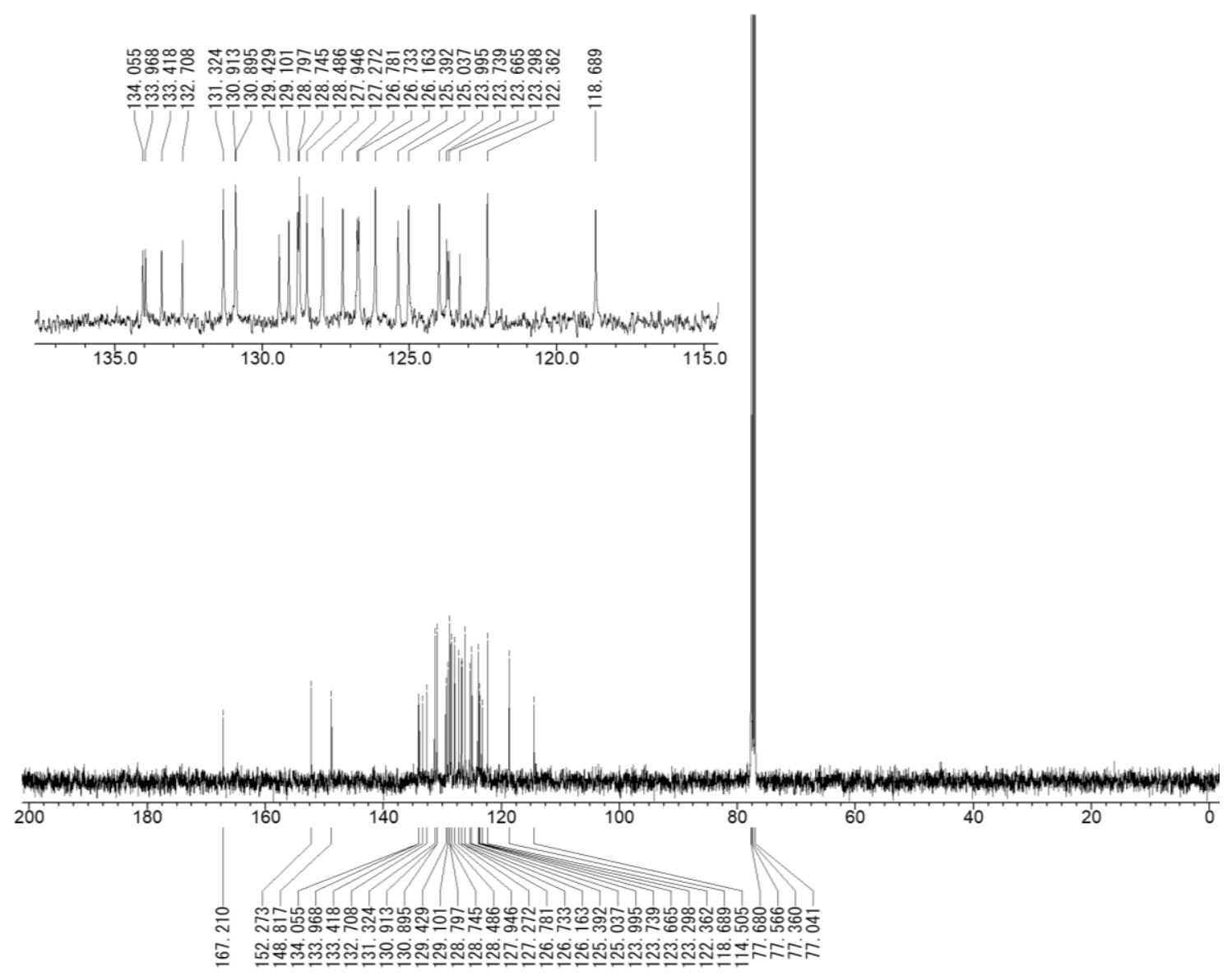

${ }^{13} \mathrm{C}$ NMR spectrum of $(R, R)-2\left(100 \mathrm{MHz}, \mathrm{CDCl}_{3}\right)$ 

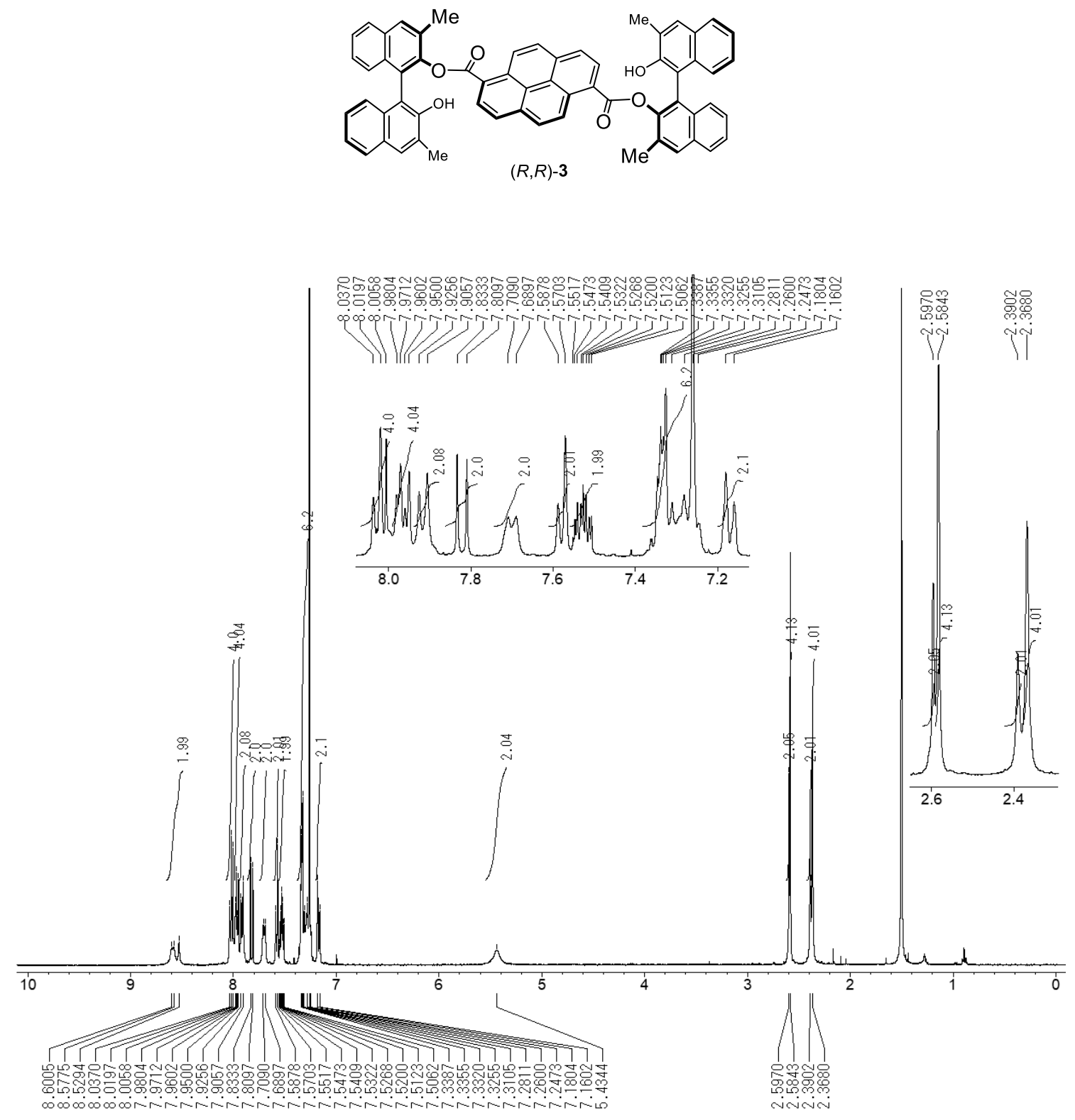

${ }^{1} \mathrm{H}$ NMR spectrum of $(R, R)-3\left(400 \mathrm{MHz}, \mathrm{CDCl}_{3}\right)$ 

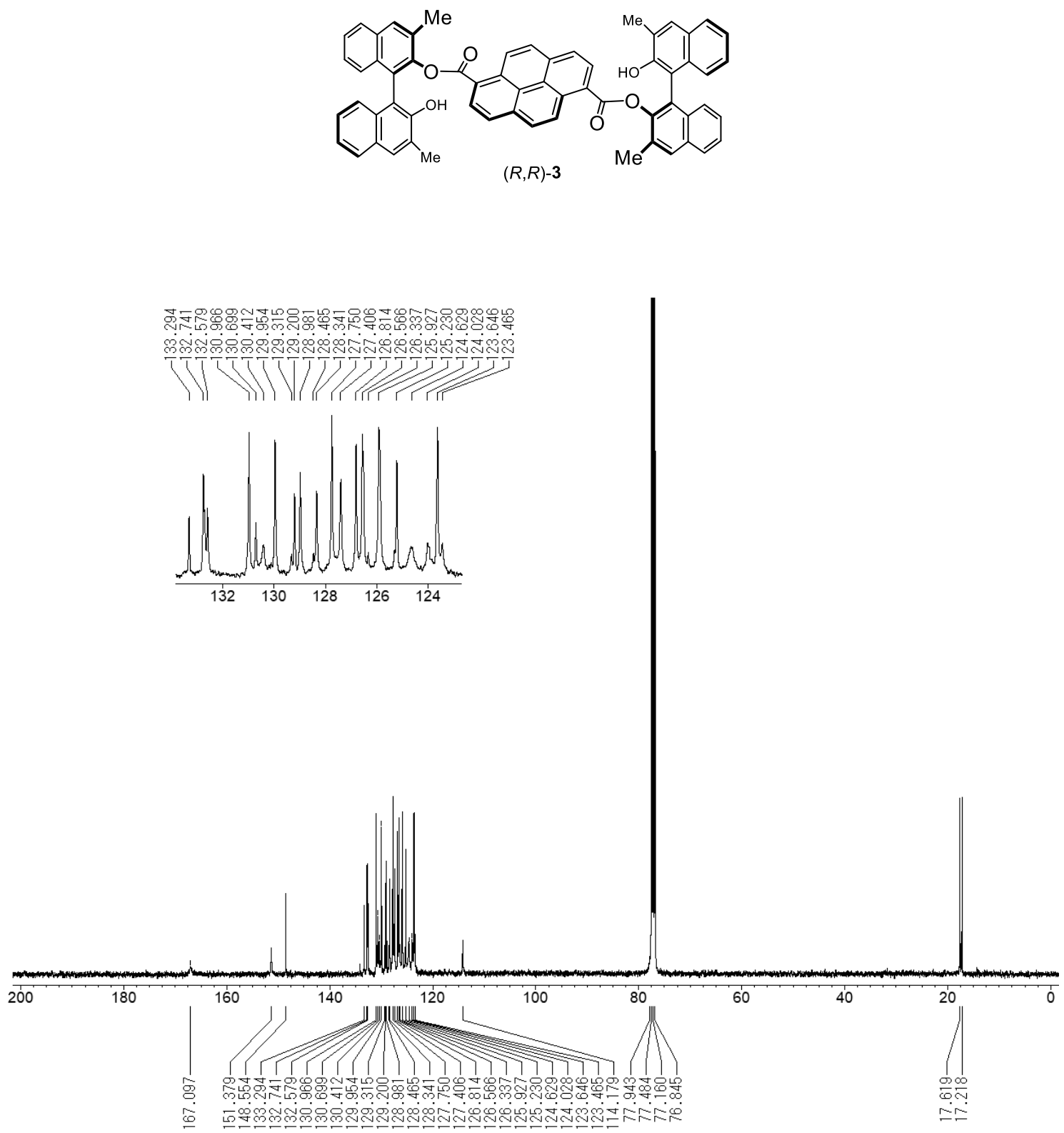

${ }^{13} \mathrm{C}$ NMR spectrum of $(R, R)-3\left(100 \mathrm{MHz}, \mathrm{CDCl}_{3}\right)$ 

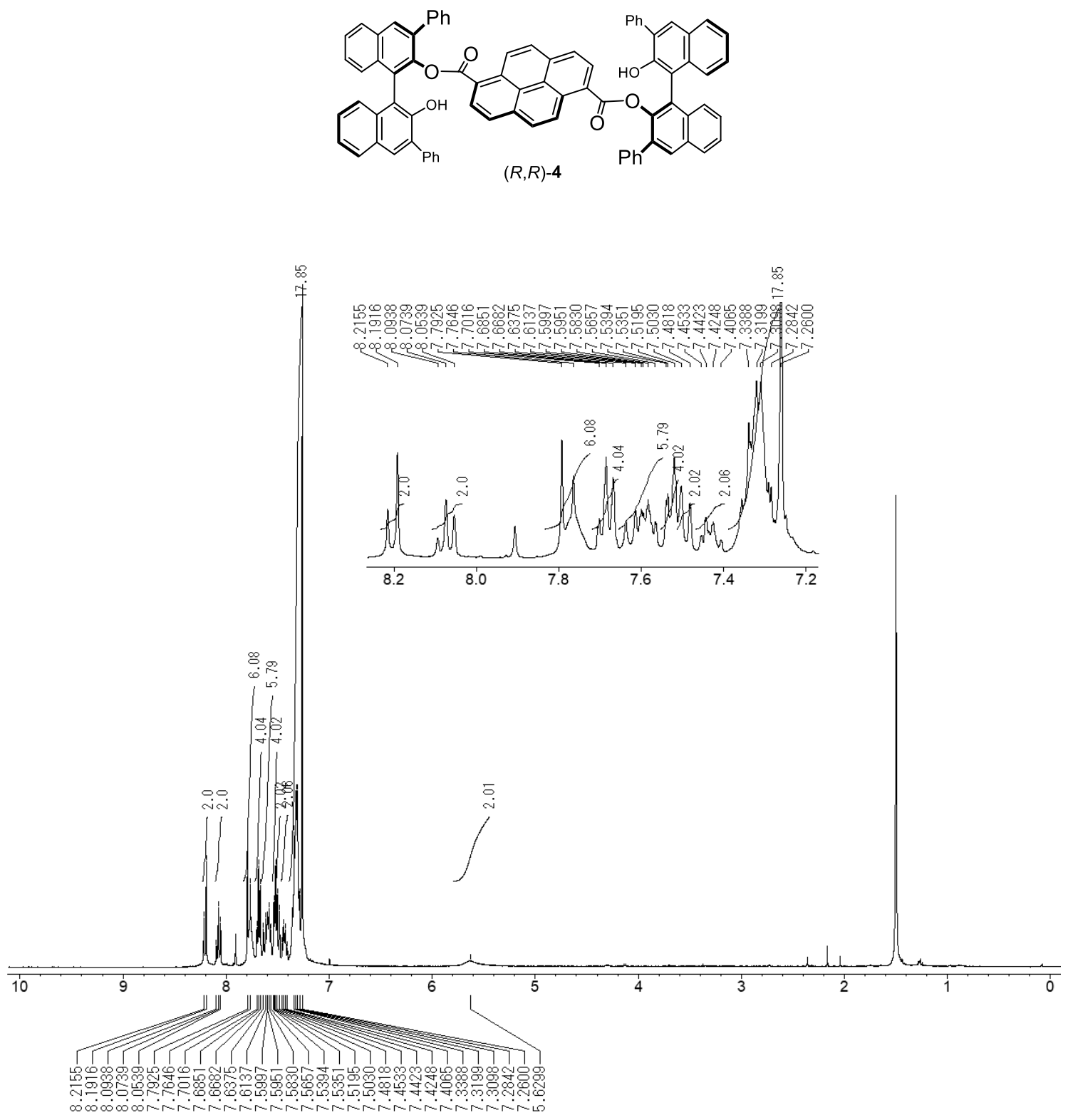

${ }^{1} \mathrm{H}$ NMR spectrum of $(R, R)-4\left(400 \mathrm{MHz}, \mathrm{CDCl}_{3}\right)$ 

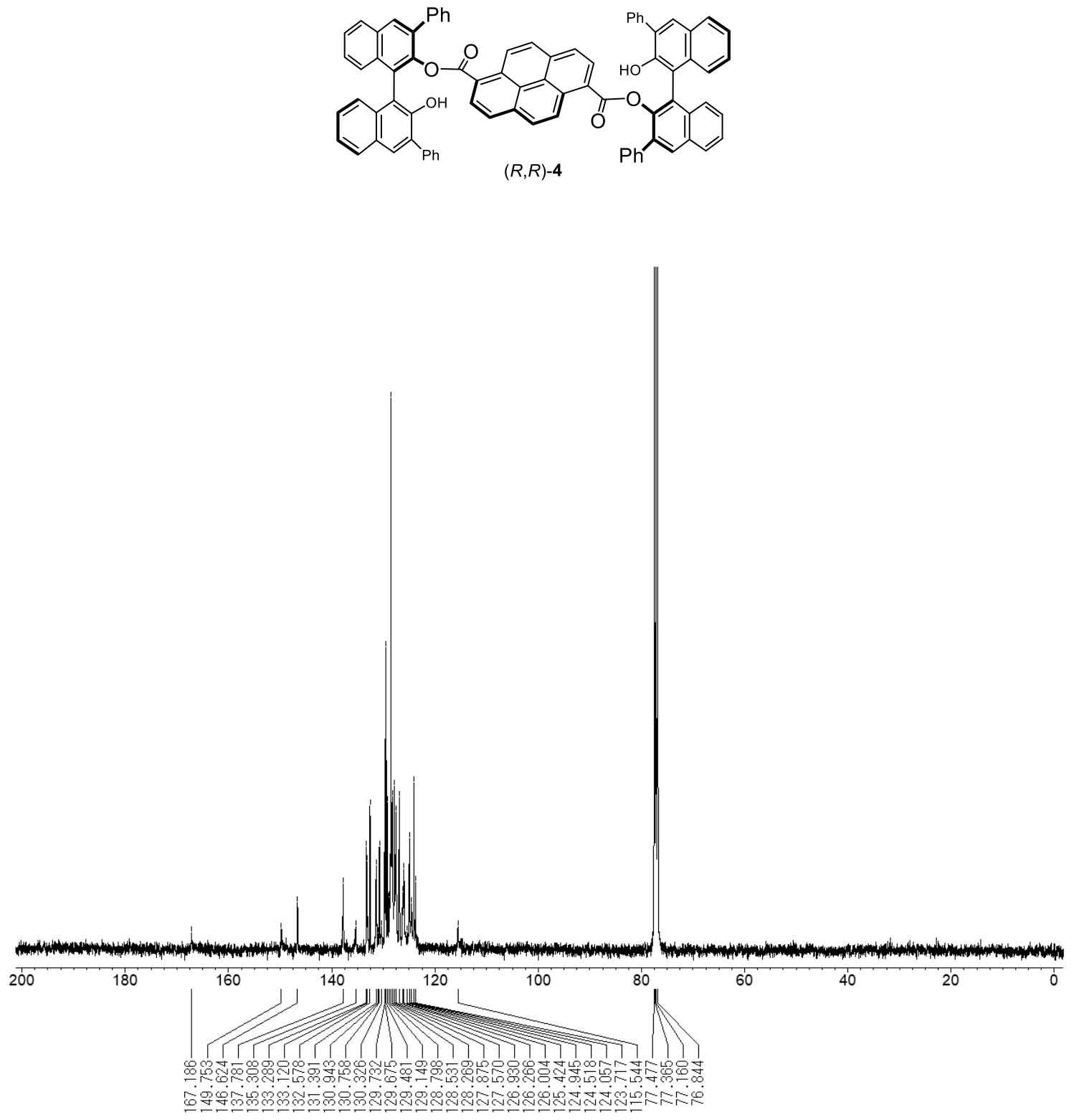

${ }^{13} \mathrm{C}$ NMR spectrum of $(R, R)-4\left(100 \mathrm{MHz}, \mathrm{CDCl}_{3}\right)$ 

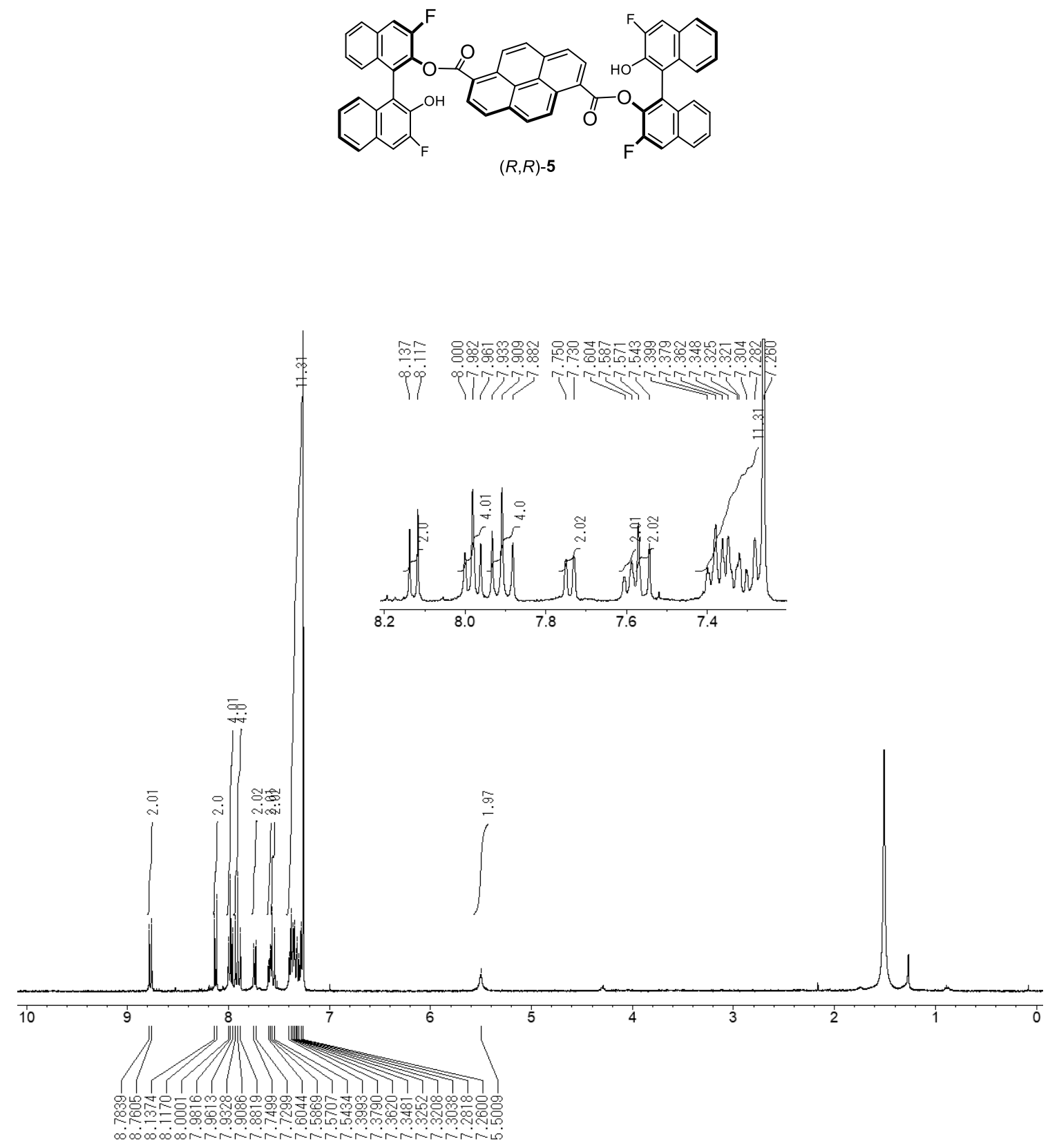

${ }^{1} \mathrm{H}$ NMR spectrum of $(R, R)-5\left(400 \mathrm{MHz}, \mathrm{CDCl}_{3}\right)$ 

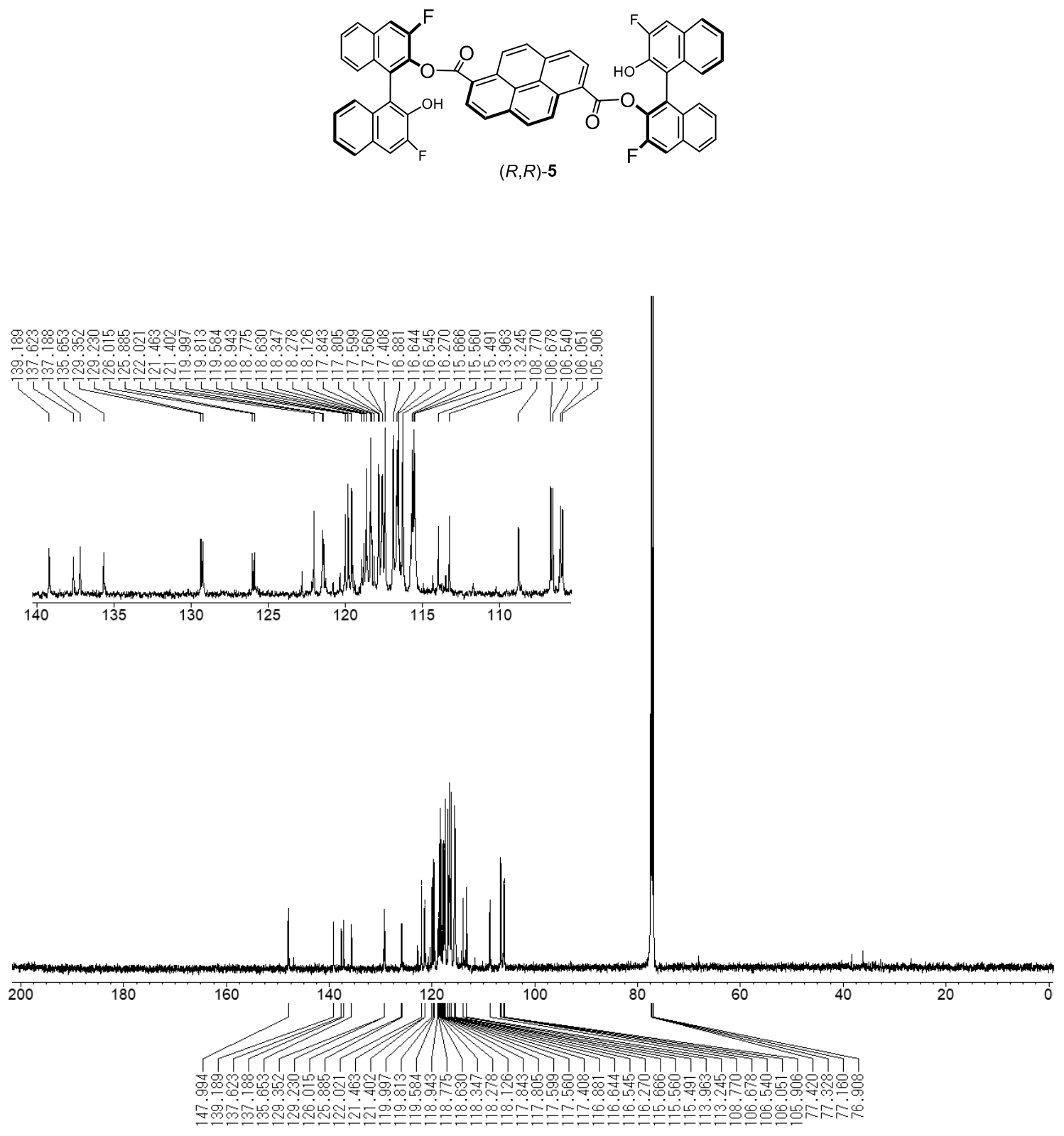

${ }^{13} \mathrm{C}$ NMR spectrum of $(R, R)-5\left(100 \mathrm{MHz}, \mathrm{CDCl}_{3}\right)$ 

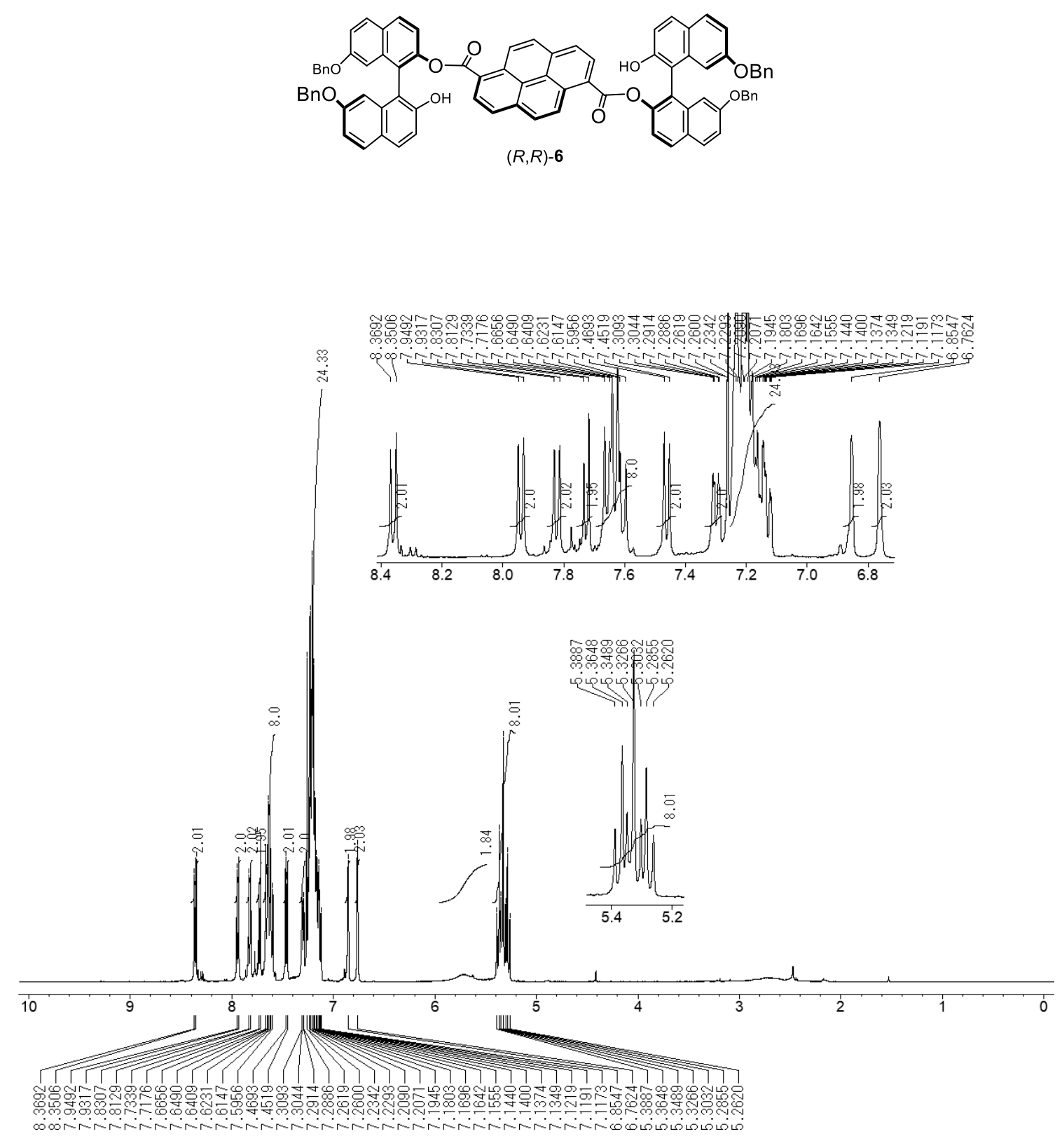

${ }^{1} \mathrm{H}$ NMR spectrum of $(R, R)-6\left(400 \mathrm{MHz}, \mathrm{CDCl}_{3}\right)$ 

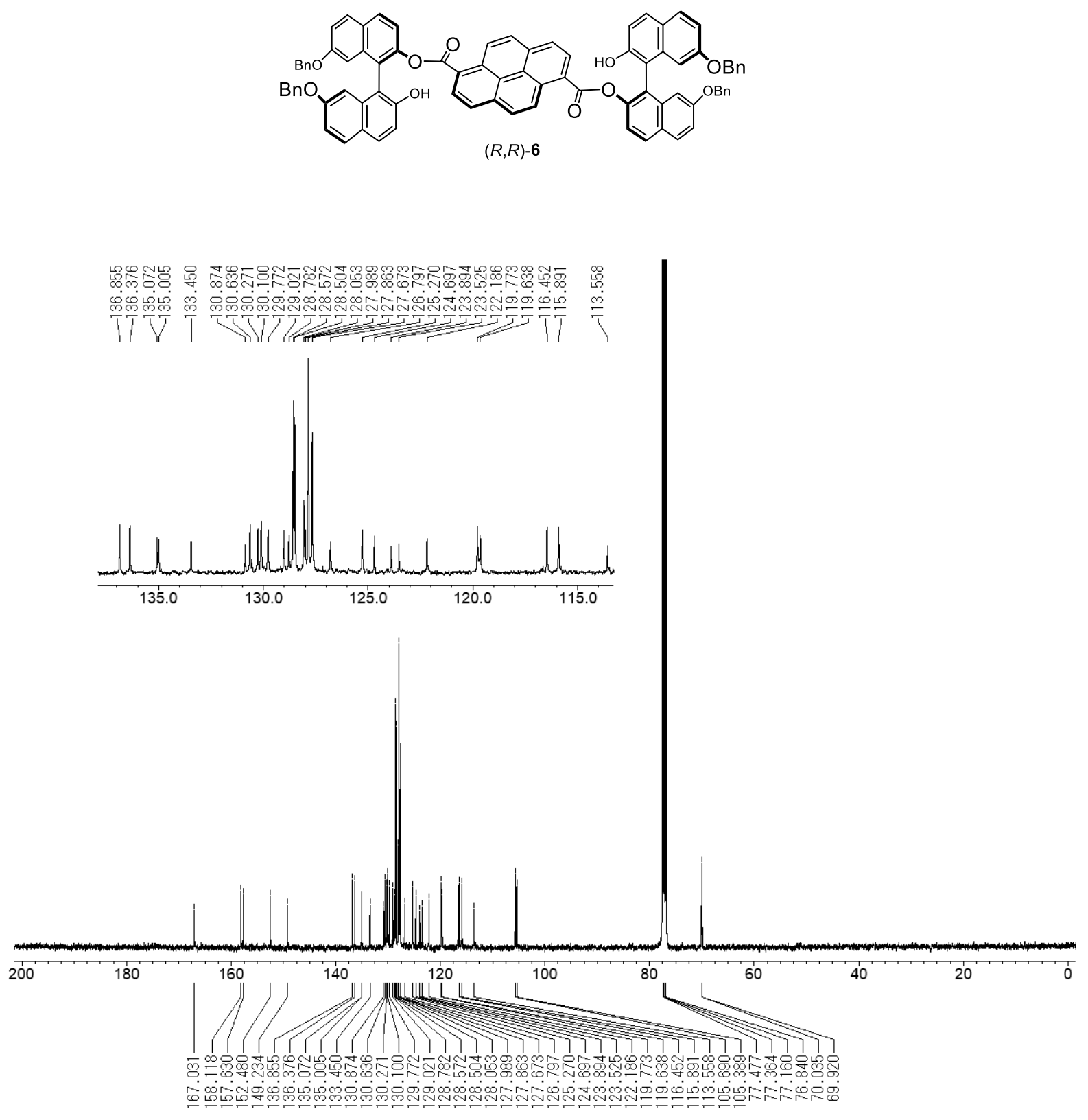

${ }^{13} \mathrm{C}$ NMR spectrum of $(R, R)-6\left(100 \mathrm{MHz}, \mathrm{CDCl}_{3}\right)$ 

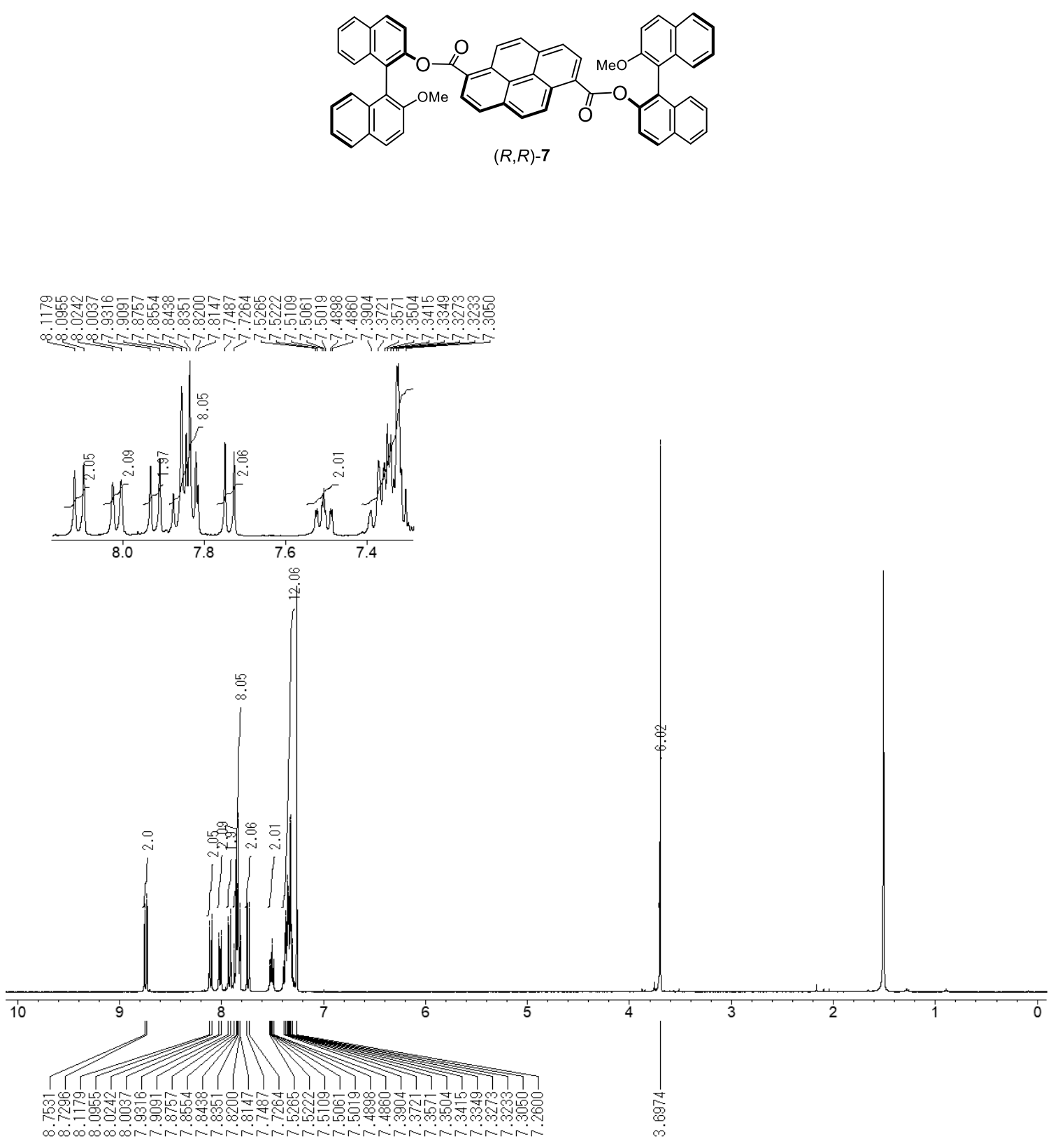

${ }^{1} \mathrm{H}$ NMR spectrum of $(R, R)-7\left(400 \mathrm{MHz}, \mathrm{CDCl}_{3}\right)$ 

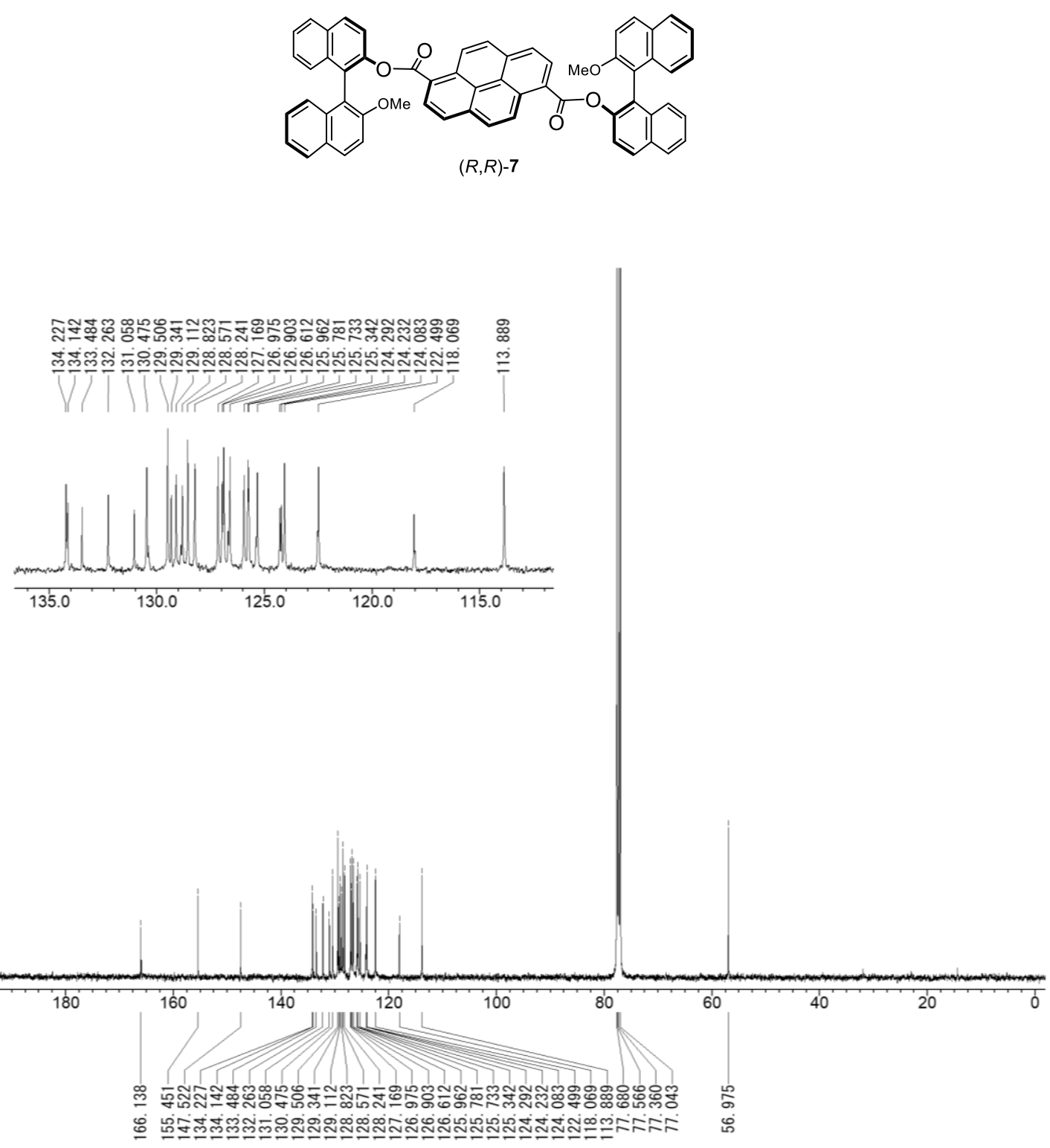

${ }^{13} \mathrm{C}$ NMR spectrum of $(R, R)-7\left(100 \mathrm{MHz}, \mathrm{CDCl}_{3}\right)$ 

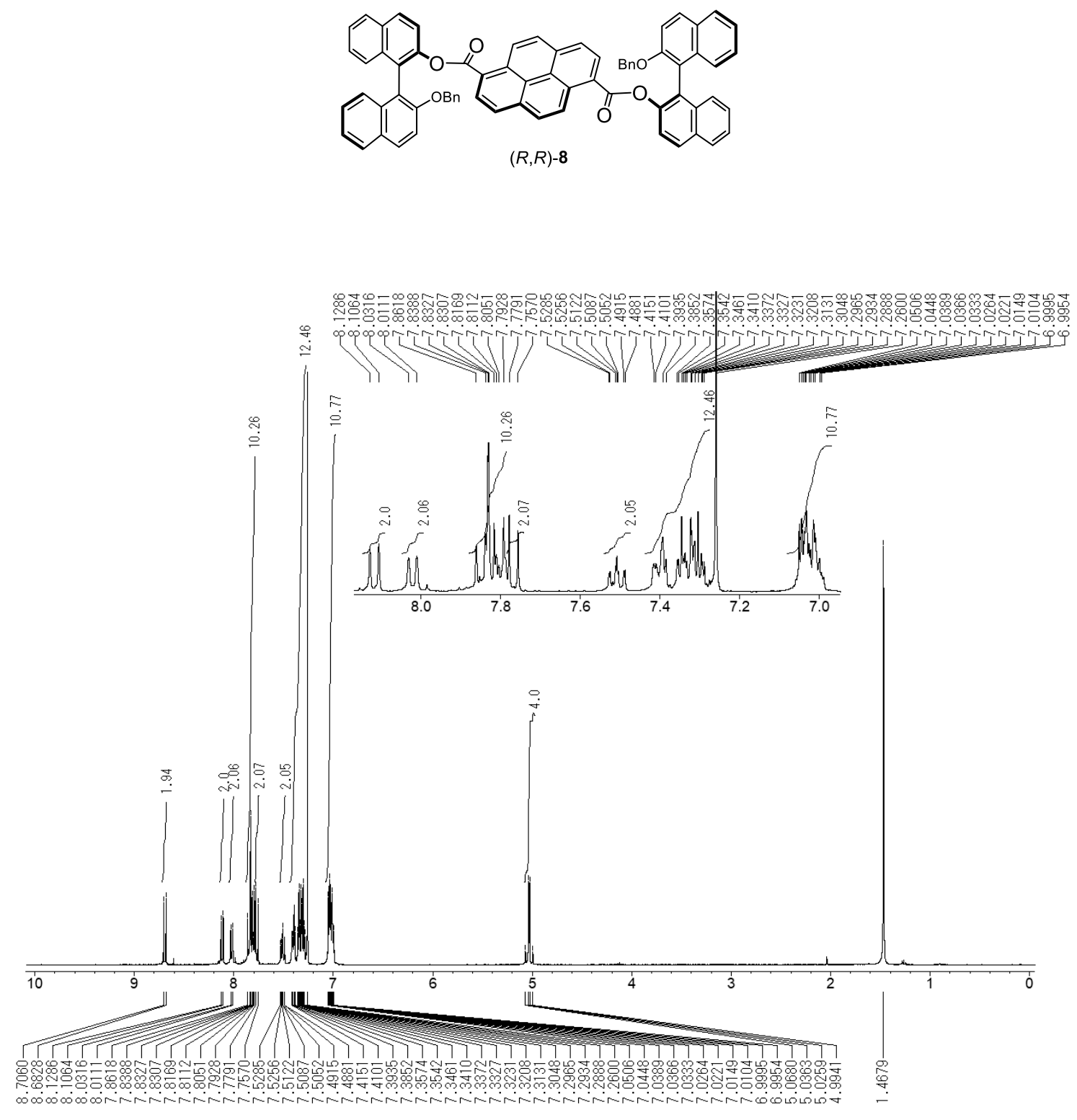

${ }^{1} \mathrm{H}$ NMR spectrum of $(R, R)-8\left(400 \mathrm{MHz}, \mathrm{CDCl}_{3}\right)$ 

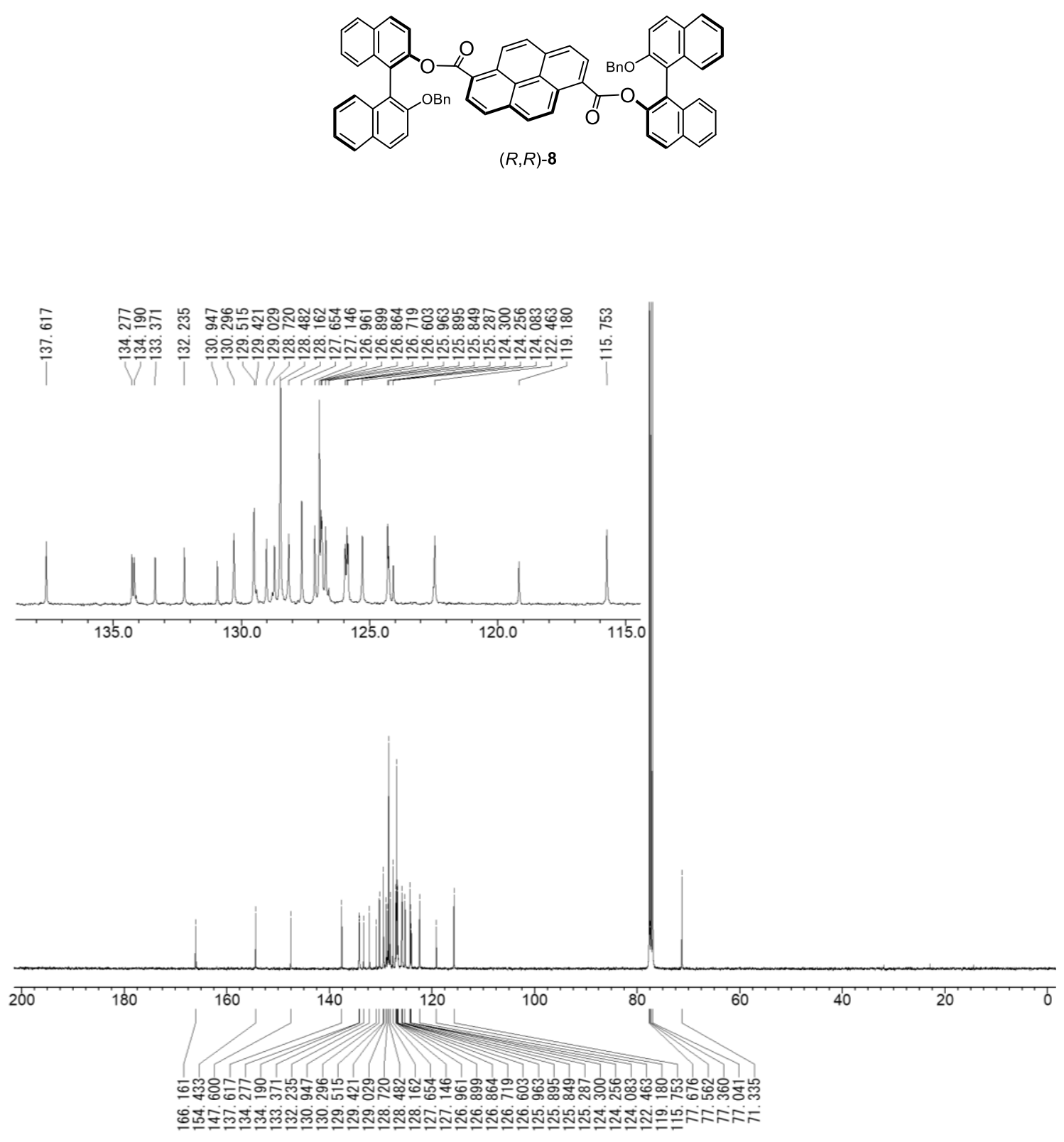

${ }^{13} \mathrm{C}$ NMR spectrum of $(R, R)-8\left(100 \mathrm{MHz}, \mathrm{CDCl}_{3}\right)$ 

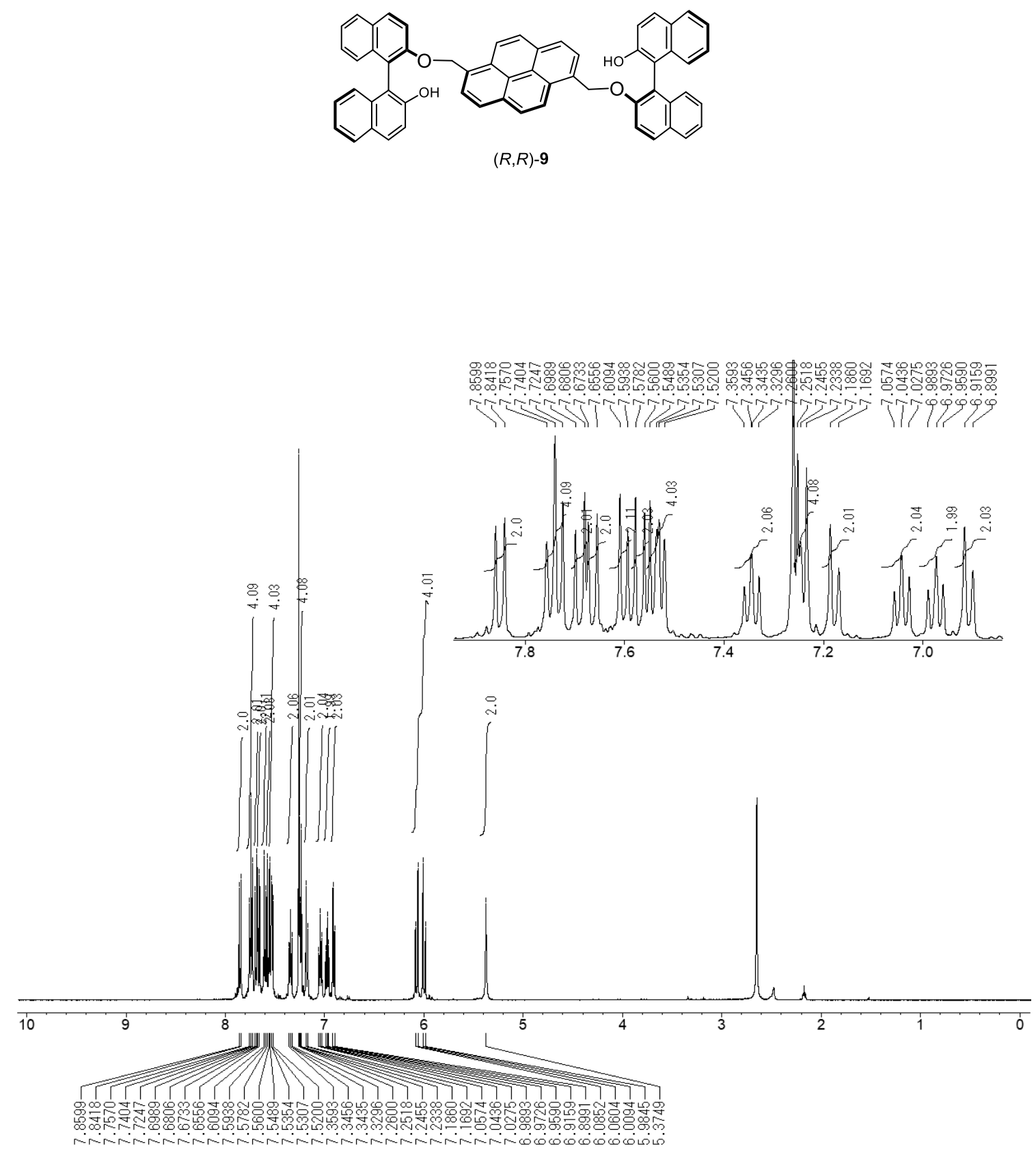

${ }^{1} \mathrm{H}$ NMR spectrum of $(R, R)-\mathbf{9}\left(400 \mathrm{MHz}, \mathrm{CDCl}_{3}\right)$ 

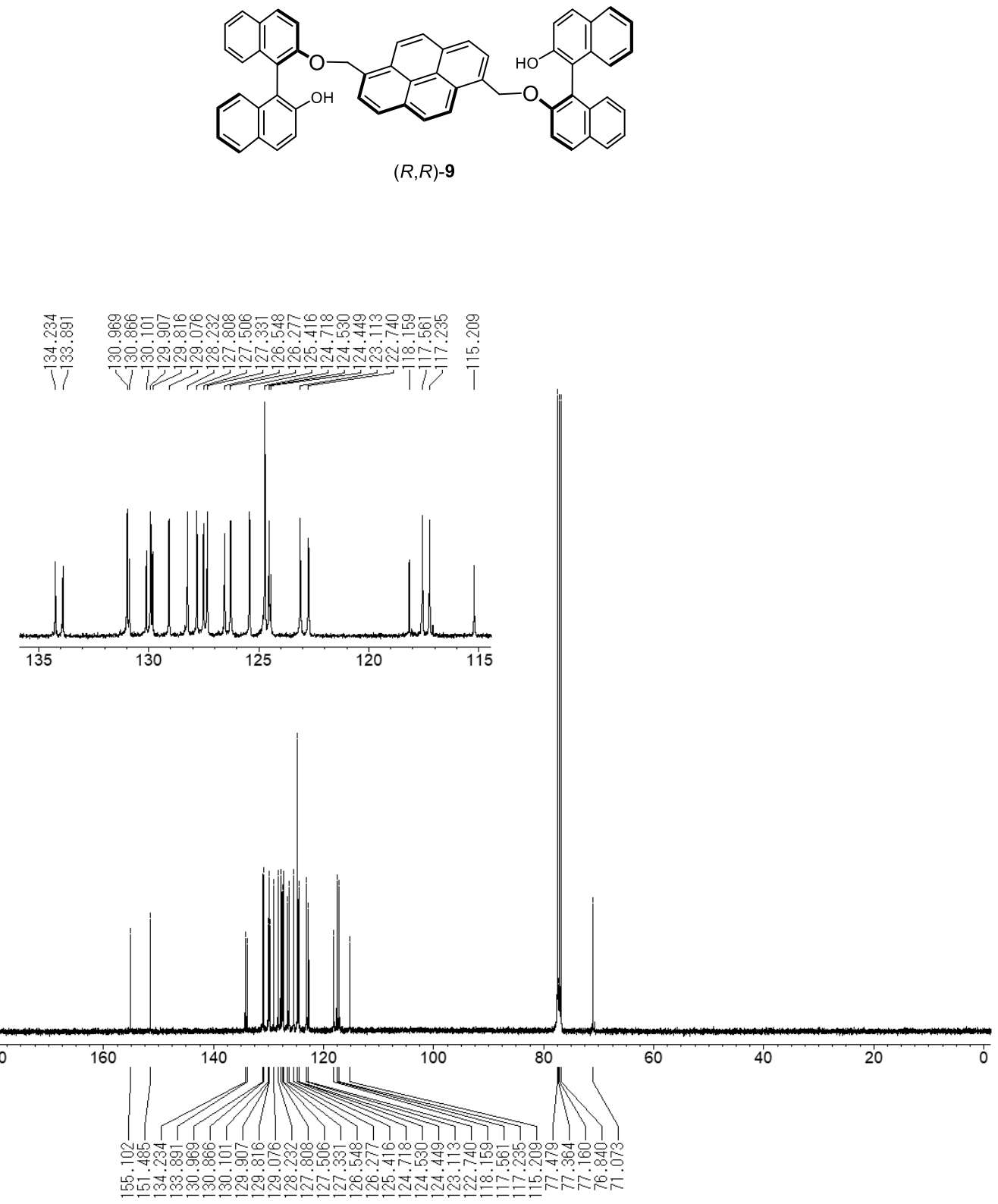

${ }^{13} \mathrm{C}$ NMR spectrum of $(R, R)-9\left(100 \mathrm{MHz}, \mathrm{CDCl}_{3}\right)$ 

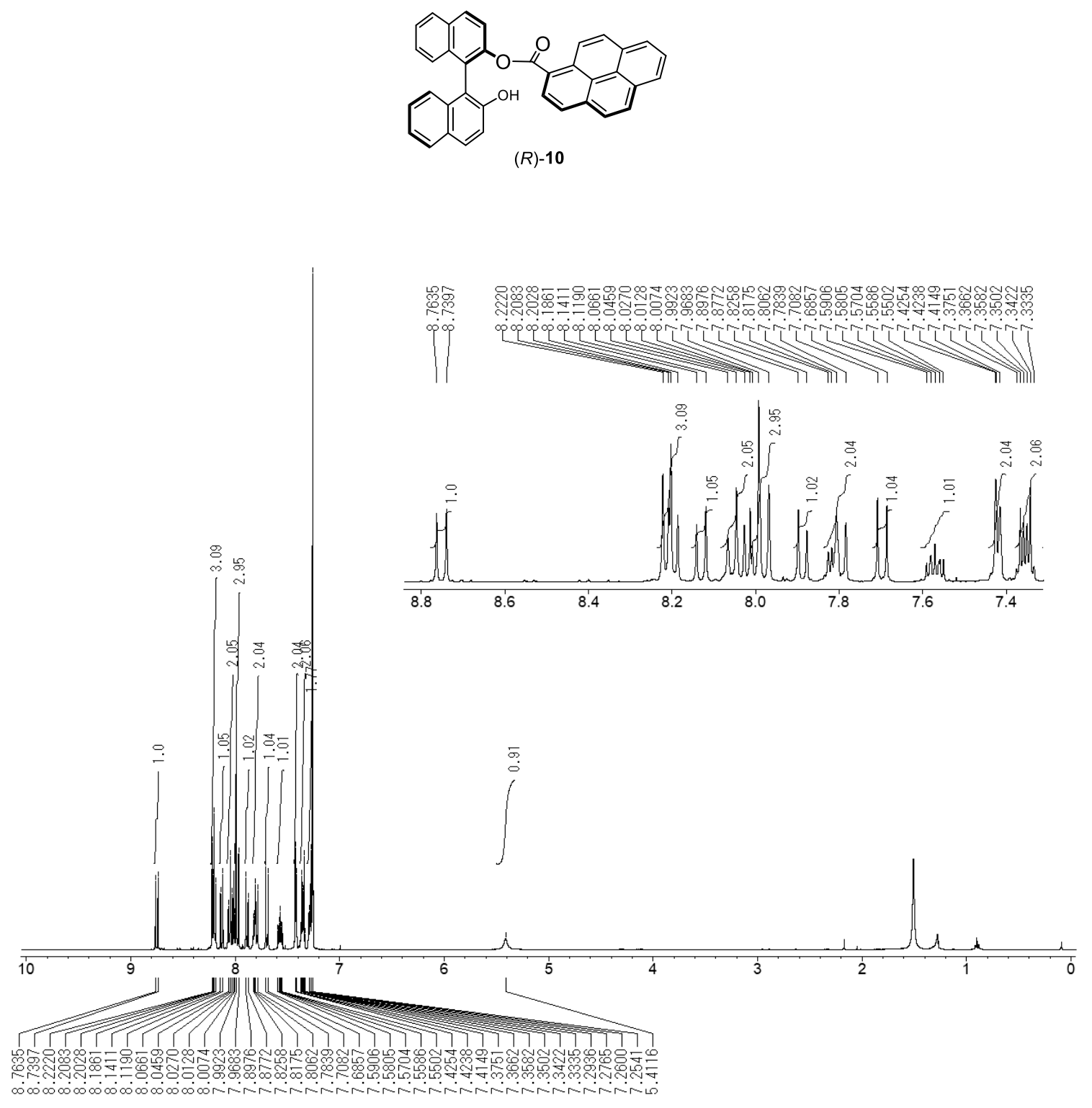

${ }^{1} \mathrm{H}$ NMR spectrum of $(R)-\mathbf{1 0}\left(400 \mathrm{MHz}, \mathrm{CDCl}_{3}\right)$ 


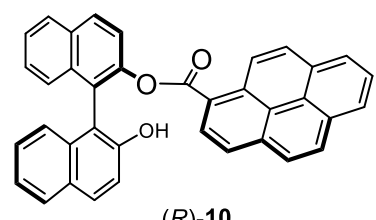

$(R)-10$

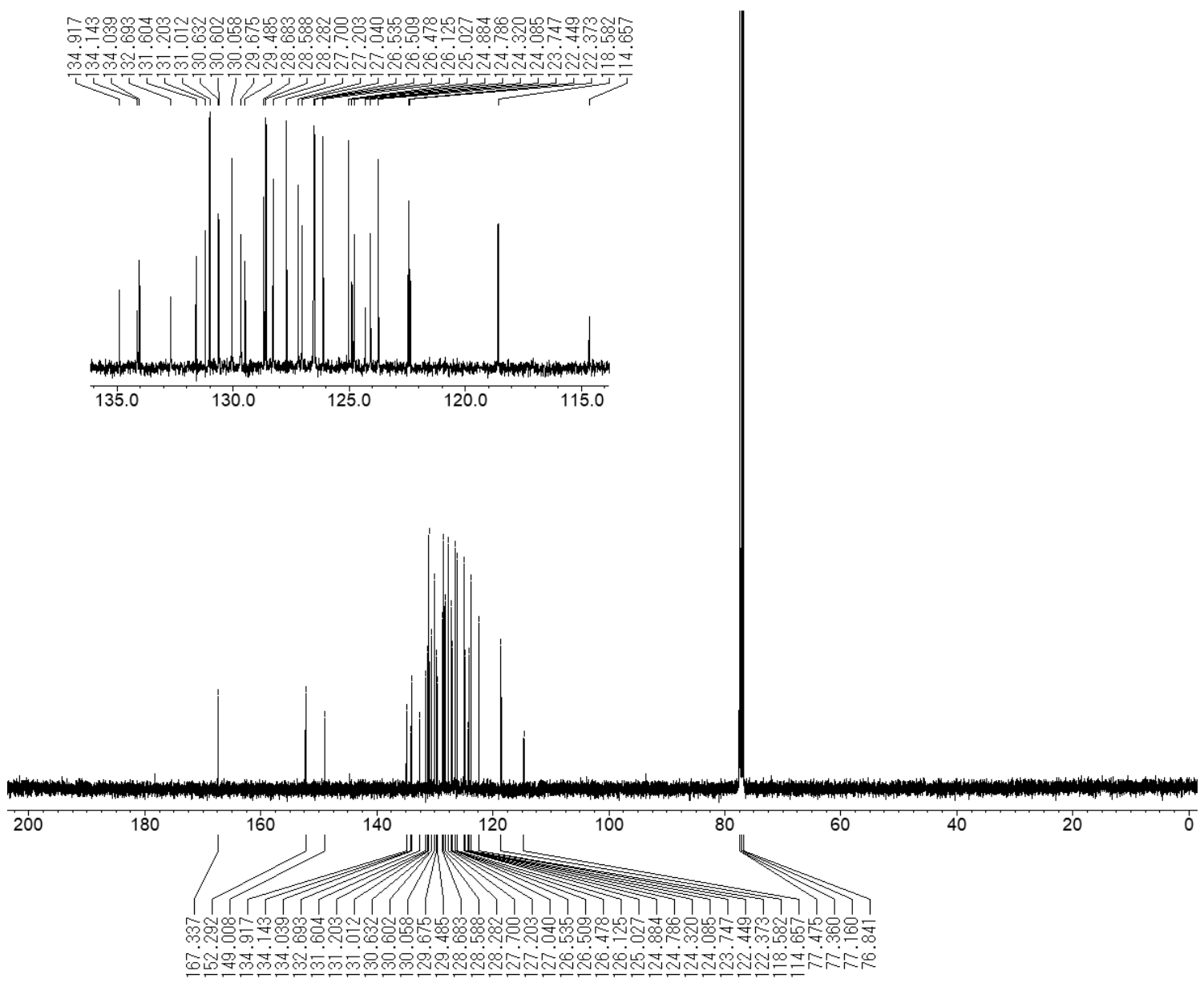

${ }^{13} \mathrm{C}$ NMR spectrum of $(R)-\mathbf{1 0}\left(100 \mathrm{MHz}, \mathrm{CDCl}_{3}\right)$ 

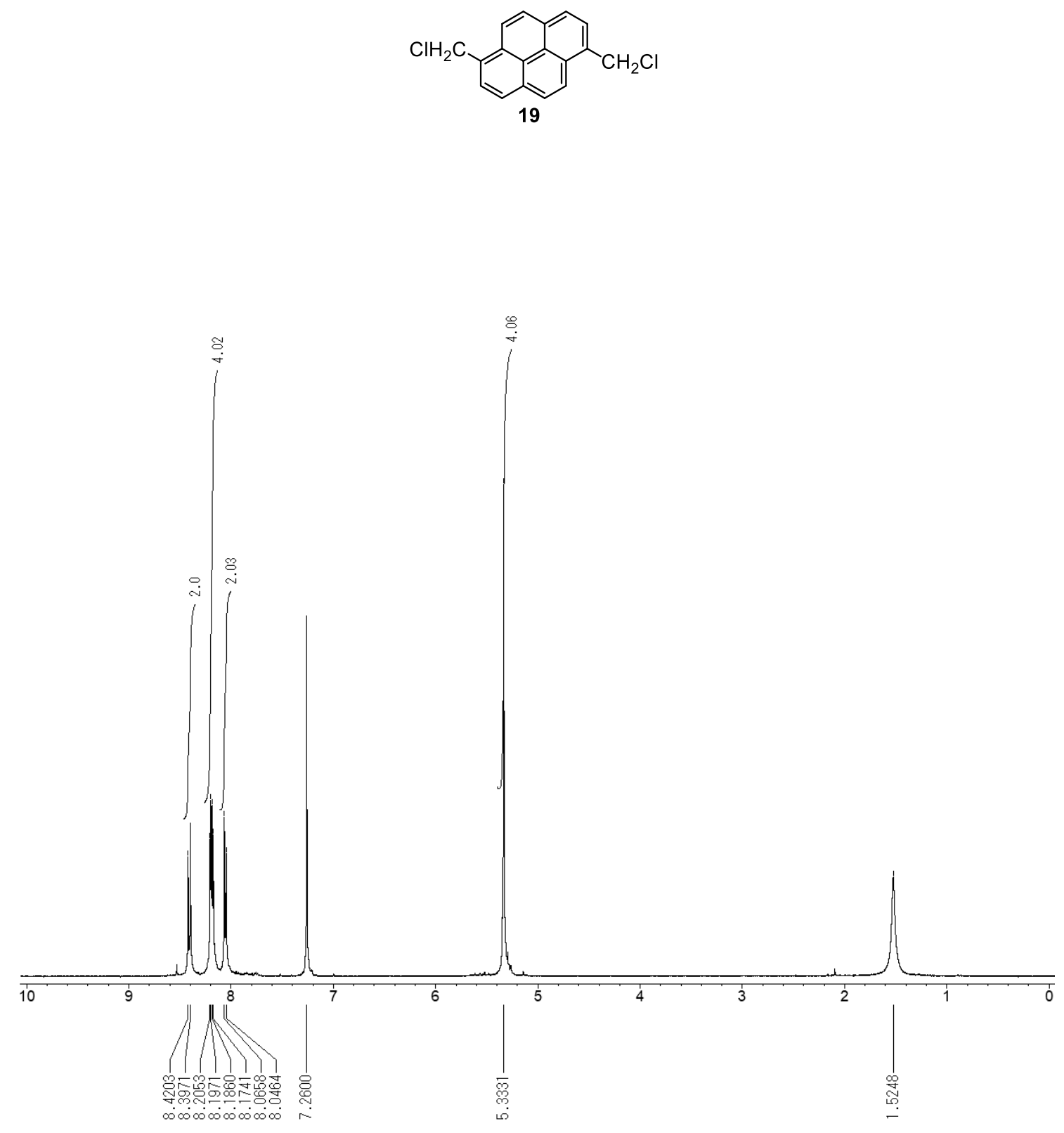

${ }^{1} \mathrm{H}$ NMR spectrum of $\mathbf{1 9}\left(400 \mathrm{MHz}, \mathrm{CDCl}_{3}\right)$ 

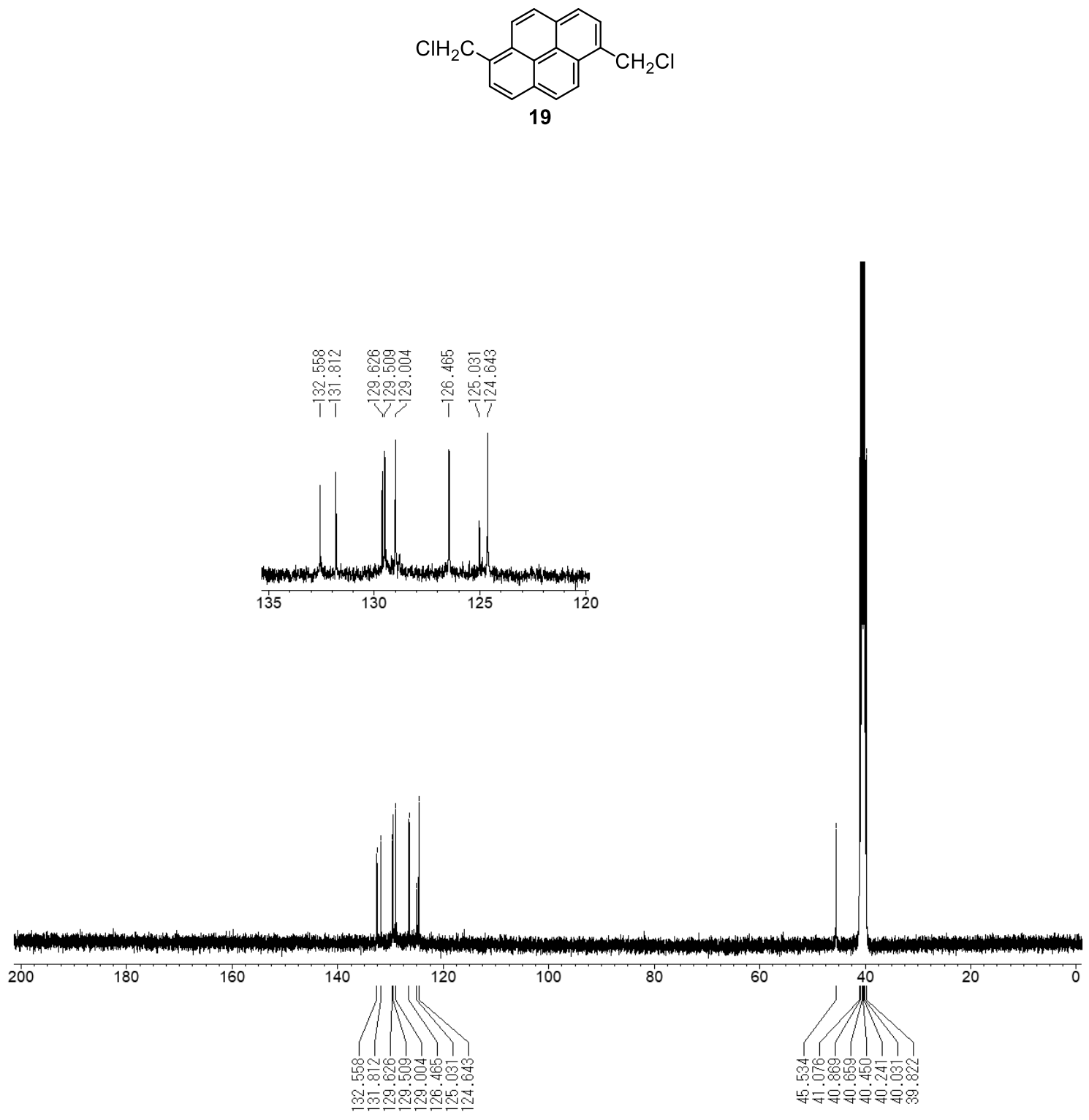

${ }^{13} \mathrm{C}$ NMR spectrum of 19 (100 MHz, DMSO- $\left.d_{6}\right)$ 


\section{Coordinates of optimized structures}

Coordinates of $\mathbf{2}$ ex $\underline{\mathbf{R} \text { in Figure } 3 .}$

\begin{tabular}{|c|c|c|c|}
\hline $\mathrm{C}$ & 0.964624 & 7.778414 & 0.390921 \\
\hline $\mathrm{C}$ & 1.909660 & 6.934430 & 1.022699 \\
\hline $\mathrm{C}$ & 3.001802 & 6.457723 & 0.332229 \\
\hline $\mathrm{C}$ & 3.212380 & 6.795879 & -1.034706 \\
\hline $\mathrm{C}$ & 2.257825 & 7.661424 & -1.66762 \\
\hline $\mathrm{C}$ & 1.142005 & 8.134241 & -0.925884 \\
\hline $\mathrm{C}$ & 4.331132 & 6.303522 & -1.78134 \\
\hline $\mathrm{C}$ & 4.474938 & 6.688738 & -3.10784 \\
\hline $\mathrm{C}$ & 3.537163 & 7.553277 & -3.728017 \\
\hline $\mathrm{C}$ & 2.455725 & 8.022850 & -3.02525 \\
\hline $\mathrm{C}$ & 5.324190 & 5.365813 & -1.17330 \\
\hline $\mathrm{C}$ & 6.624296 & 5.806237 & -0.75651 \\
\hline $\mathrm{C}$ & 7.540650 & 4.859252 & -0.19117 \\
\hline $\mathrm{C}$ & 7.139001 & 3.504990 & -0.040743 \\
\hline $\mathrm{C}$ & 5.890058 & 3.088725 & -0.429332 \\
\hline $\mathrm{C}$ & 5.008583 & 4.034022 & -0.997406 \\
\hline $\mathrm{C}$ & 7.039058 & 7.160012 & -0.875447 \\
\hline $\mathrm{C}$ & 8.292778 & 7.555549 & -0.466095 \\
\hline $\mathrm{C}$ & 9.198913 & 6.618805 & 0.084280 \\
\hline $\mathrm{C}$ & 8.826778 & 5.301164 & 0.21 \\
\hline $\mathrm{O}$ & 5.544437 & 6.204199 & -3.80421 \\
\hline $\mathrm{O}$ & 3.697884 & 3.631623 & -1.310210 \\
\hline $\mathrm{C}$ & 3.498654 & 2.667937 & -2.2403 \\
\hline $\mathrm{O}$ & 4.369091 & 2.156118 & -2.9065 \\
\hline $\mathrm{C}$ & 2.039257 & 2.325690 & -2.318988 \\
\hline $\mathrm{C}$ & 1.627373 & 0.962731 & -2.47522 \\
\hline $\mathrm{C}$ & 0.228506 & 0.674277 & -2.49328 \\
\hline $\mathrm{C}$ & -0.721929 & 1.732274 & -2.43058 \\
\hline $\mathrm{C}$ & -0.266428 & 3.059517 & -2.2519 \\
\hline $\mathrm{C}$ & 1.094284 & 3.343885 & -2.1940 \\
\hline $\mathrm{C}$ & -2.105047 & 1.423669 & -2.486037 \\
\hline $\mathrm{C}$ & 2.549608 & -0.118491 & -2.5204 \\
\hline $\mathrm{C}$ & -0.963761 & -7.777998 & 0.39 \\
\hline
\end{tabular}




\begin{tabular}{|c|c|c|c|}
\hline $\mathrm{C}$ & -1.909734 & -6.934441 & 1.023289 \\
\hline $\mathrm{C}$ & -3.001236 & -6.457847 & 0.331725 \\
\hline $\mathrm{C}$ & -3.210184 & -6.795678 & -1.035543 \\
\hline C & -2.254677 & -7.660784 & 1.667626 \\
\hline $\mathrm{C}$ & -1.139571 & -8.133511 & -0.924760 \\
\hline $\mathrm{C}$ & -4.328206 & -6.303383 & -1.783313 \\
\hline $\mathrm{C}$ & -4.470378 & -6.688221 & -3.110101 \\
\hline C & -3.531672 & -7.552337 & -3.729449 \\
\hline $\mathrm{C}$ & -2.450925 & -8.021851 & -3.025585 \\
\hline $\mathrm{C}$ & -5.322198 & -5.366104 & -1.176136 \\
\hline $\mathrm{C}$ & -6.622801 & -5.806905 & -0.761273 \\
\hline $\mathrm{C}$ & -7.540055 & -4.860303 & -0.196749 \\
\hline $\mathrm{C}$ & -7.138810 & -3.506046 & -0.045161 \\
\hline $\mathrm{C}$ & -5.889400 & -3.089444 & -0.431865 \\
\hline $\mathrm{C}$ & -5.007023 & -4.034351 & -0.999181 \\
\hline $\mathrm{C}$ & -7.037215 & -7.160681 & -0.881379 \\
\hline $\mathrm{C}$ & -8.291436 & -7.556578 & -0.473910 \\
\hline $\mathrm{C}$ & -9.198447 & -6.620211 & 0.075660 \\
\hline $\mathrm{C}$ & -8.826676 & -5.302578 & 0.211280 \\
\hline $\mathrm{O}$ & -5.539200 & -6.203754 & -3.807549 \\
\hline $\mathrm{O}$ & -3.695994 & -3.631558 & -1.309977 \\
\hline $\mathrm{C}$ & -3.495705 & -2.667544 & -2.239588 \\
\hline $\mathrm{O}$ & -4.365426 & -2.155937 & -2.906882 \\
\hline $\mathrm{C}$ & -0.225397 & -0.673886 & -2.49 \\
\hline $\mathrm{C}$ & -1.624283 & -0.962320 & -2.474610 \\
\hline $\mathrm{C}$ & -2.546459 & 0.118855 & -2.522467 \\
\hline $\mathrm{C}$ & 2.108171 & -1.423235 & -2.481516 \\
\hline $\mathrm{C}$ & 0.725036 & -1.731694 & -2.426210 \\
\hline $\mathrm{C}$ & 0.269461 & -3.058548 & -2.244683 \\
\hline $\mathrm{C}$ & -1.091353 & -3.342902 & -2.188196 \\
\hline $\mathrm{C}$ & -2.036255 & -2.325075 & -2.316418 \\
\hline $\mathrm{H}$ & 0.107544 & 8.144322 & 0.947822 \\
\hline $\mathrm{H}$ & 1.773790 & 6.663584 & 2.065644 \\
\hline $\mathrm{H}$ & 3.721091 & 5.817454 & 0.830591 \\
\hline $\mathrm{H}$ & 0.428394 & 8.787315 & -1.421939 \\
\hline $\mathrm{H}$ & 3.681856 & 7.833972 & -4.76928 \\
\hline
\end{tabular}




\begin{tabular}{|c|c|c|c|}
\hline $\mathrm{H}$ & 1.737459 & 8.681053 & -3.5 \\
\hline $\mathrm{H}$ & 7.832543 & 2.794207 & 0.39908 \\
\hline $\mathrm{H}$ & 5.572750 & 2.059367 & -0.29857 \\
\hline $\mathrm{H}$ & 6.347543 & 7.884366 & -1.29159 \\
\hline $\mathrm{H}$ & 8.589421 & 8.595741 & -0.5646 \\
\hline $\mathrm{H}$ & 10.185067 & 6.943670 & 0.40248 \\
\hline $\mathrm{H}$ & 9.513041 & 4.574301 & 0.64516 \\
\hline $\mathrm{H}$ & 5.519623 & 6.546188 & -4.70710 \\
\hline $\mathrm{H}$ & -0.993242 & 3.859571 & -2.16711 \\
\hline $\mathrm{H}$ & 1.430799 & 4.360788 & -2.03249 \\
\hline $\mathrm{H}$ & -2.825326 & 2.234343 & -2.4589 \\
\hline $\mathrm{H}$ & 3.609223 & 0.093750 & -2.53646 \\
\hline $\mathrm{H}$ & -0.107204 & -8.143822 & 0.950 \\
\hline $\mathrm{H}$ & -1.775105 & -6.663838 & 2.06 \\
\hline $\mathrm{H}$ & -3.721266 & -5.817920 & 0.8294 \\
\hline $\mathrm{H}$ & -0.425222 & -8.786249 & -1.42019 \\
\hline $\mathrm{H}$ & -3.675093 & -7.832748 & 4.77 \\
\hline $\mathrm{H}$ & -1.731935 & -8.679719 & -3.50613 \\
\hline $\mathrm{H}$ & -7.833051 & -2.795566 & $0.39405 t$ \\
\hline $\mathrm{H}$ & -5.572290 & -2.060144 & -0.30022 \\
\hline $\mathrm{H}$ & -6.345043 & -7.884752 & -1.296 \\
\hline $\mathrm{H}$ & -8.587800 & -8.596766 & -0.57332 \\
\hline $\mathrm{H}$ & -10.184986 & -6.945355 & 0.39238 \\
\hline $\mathrm{H}$ & -9.513618 & -4.576004 & 0.6370 \\
\hline $\mathrm{H}$ & -5.513185 & -6.545355 & -4.71055 \\
\hline $\mathrm{H}$ & -3.606061 & -0.093412 & -2.53870 \\
\hline $\mathrm{H}$ & 2.828414 & -2.233853 & -2.45 \\
\hline $\mathrm{H}$ & 0.996198 & -3.858378 & -2.1575 \\
\hline $\mathrm{H}$ & -1.428001 & -4.359517 & -2.02522 \\
\hline $\mathrm{C}$ & -5.158973 & 8.452911 & $1.934 \mathrm{C}$ \\
\hline $\mathrm{C}$ & -5.928321 & 7.782106 & 0.9542 \\
\hline $\mathrm{C}$ & -6.205991 & 6.438995 & 1.0735 \\
\hline $\mathrm{C}$ & -5.730875 & 5.683930 & 2.18 \\
\hline $\mathrm{C}$ & -4.938961 & 6.366100 & 3.1682 \\
\hline $\mathrm{C}$ & -4.675233 & 7.753420 & 3.0159 \\
\hline $\mathrm{C}$ & -6.003954 & 4.286079 & 2.33 \\
\hline
\end{tabular}




\begin{tabular}{|c|c|c|c|}
\hline $\mathrm{C}$ & -5.465501 & 3.612594 & $3.42045^{\prime}$ \\
\hline $\mathrm{C}$ & -4.682533 & 4.286531 & 4.39073 \\
\hline $\mathrm{C}$ & -4.429548 & 5.629773 & 85 \\
\hline $\mathrm{C}$ & -6.820766 & 3.534757 & 1.330404 \\
\hline $\mathrm{C}$ & -8.243292 & 3.697785 & 1.24909 \\
\hline $\mathrm{C}$ & -8.983190 & 2.967153 & 0.261 \\
\hline $\mathrm{C}$ & -8.287344 & 2.092253 & -0.613255 \\
\hline $\mathrm{C}$ & -6.927984 & 1.929888 & -0.51830 \\
\hline $\mathrm{C}$ & -6.202931 & 2.648479 & 0.4622 \\
\hline $\mathrm{C}$ & -8.963510 & 4.552120 & 2.13010 \\
\hline $\mathrm{C}$ & -10.330551 & 4.685155 & 2.03224 \\
\hline $\mathrm{C}$ & -11.055491 & 3.973232 & 1.04760 \\
\hline $\mathrm{C}$ & -10.391735 & 3.132285 & 0.18439 \\
\hline $\mathrm{O}$ & -5.720785 & 2.276865 & 3.538 \\
\hline $\mathrm{O}$ & -4.823415 & 2.565741 & 0.5264 \\
\hline $\mathrm{C}$ & -4.191999 & 1.326168 & 0.65422 \\
\hline $\mathrm{O}$ & -4.833837 & 0.287542 & 0.562604 \\
\hline $\mathrm{C}$ & -2.754659 & 1.483775 & 085 \\
\hline $\mathrm{C}$ & -1.879423 & 0.338094 & 1.00622 \\
\hline $\mathrm{C}$ & -0.455514 & 0.555018 & 1.038558 \\
\hline $\mathrm{C}$ & 0.071174 & 1.885185 & 1.02618 \\
\hline $\mathrm{C}$ & -0.826433 & 2.983757 & 0.85 \\
\hline $\mathrm{C}$ & -2.185497 & 2.781309 & 0.82822 \\
\hline $\mathrm{C}$ & 1.466948 & 2.066265 & 1.112775 \\
\hline $\mathrm{C}$ & -2.344817 & -0.998159 & 1.10645 \\
\hline $\mathrm{C}$ & 5.156363 & -8.452934 & 1.936622 \\
\hline $\mathrm{C}$ & 5.926446 & -7.782312 & 0.956439 \\
\hline $\mathrm{C}$ & 6.203994 & -6.439169 & 1.07 \\
\hline $\mathrm{C}$ & 5.728013 & -5.683892 & 2.185512 \\
\hline $\mathrm{C}$ & 4.935365 & -6.365879 & 3.1693 \\
\hline $\mathrm{C}$ & 4.671782 & -7.753235 & 3.01712 \\
\hline $\mathrm{C}$ & 6.000939 & -4.286003 & 2.3333 \\
\hline $\mathrm{C}$ & 5.461644 & -3.612312 & 3.4214 \\
\hline $\mathrm{C}$ & 4.677956 & -4.286069 & 4.3912 \\
\hline $\mathrm{C}$ & 4.425095 & -5.629340 & 4.2684 \\
\hline $\mathrm{C}$ & 6.818436 & -3.534850 & 1.3323 \\
\hline
\end{tabular}




\begin{tabular}{|c|c|c|c|}
\hline $\mathrm{C}$ & 8.241035 & -3.697814 & 1.25208 \\
\hline $\mathrm{C}$ & 8.981590 & -2.967373 & 0.2646 \\
\hline $\mathrm{C}$ & 8.286318 & -2.092720 & -0.61062 \\
\hline $\mathrm{C}$ & 6.926883 & -1.930426 & -0.516664 \\
\hline $\mathrm{C}$ & 6.201176 & -2.648818 & 0.46355 \\
\hline $\mathrm{C}$ & 8.960664 & -4.551911 & 2.133 \\
\hline $\mathrm{C}$ & 10.327782 & -4.684900 & 2.03694 \\
\hline $\mathrm{C}$ & 11.053381 & -3.973167 & 1.05265 \\
\hline $\mathrm{C}$ & 10.390197 & -3.132454 & 0.18877 \\
\hline $\mathrm{O}$ & 5.716810 & -2.276552 & 3.53896 \\
\hline $\mathrm{O}$ & 4.821590 & -2.566078 & 0.52665 \\
\hline $\mathrm{C}$ & 4.190236 & -1.326435 & 0.65492 \\
\hline $\mathrm{O}$ & 4.832179 & -0.287847 & 0.563712 \\
\hline $\mathrm{C}$ & 0.453684 & -0.555160 & 1.03850 \\
\hline $\mathrm{C}$ & 1.877613 & -0.338248 & 1.00632 \\
\hline $\mathrm{C}$ & 2.342997 & 0.998010 & 1.10636 \\
\hline $\mathrm{C}$ & -1.468766 & -2.066416 & 1.112807 \\
\hline $\mathrm{C}$ & -0.073038 & -1.885314 & 1.02 \\
\hline $\mathrm{C}$ & 0.824520 & -2.983876 & 0.89656 \\
\hline $\mathrm{C}$ & 2.183643 & -2.781476 & 0.827895 \\
\hline $\mathrm{C}$ & 2.752875 & -1.484001 & 0.854074 \\
\hline $\mathrm{H}$ & -4.951658 & 9.513710 & 1.82 \\
\hline $\mathrm{H}$ & -6.304044 & 8.333950 & 0.097215 \\
\hline $\mathrm{H}$ & -6.795031 & 5.937761 & 0.313965 \\
\hline $\mathrm{H}$ & -4.078012 & 8.253290 & 3.77466 \\
\hline $\mathrm{H}$ & -4.285605 & 3.725811 & 5.234397 \\
\hline $\mathrm{H}$ & -3.830081 & 6.142436 & 5.015210 \\
\hline $\mathrm{H}$ & -8.849257 & 1.544239 & -1.36 \\
\hline $\mathrm{H}$ & -6.397715 & 1.253706 & -1.175525 \\
\hline $\mathrm{H}$ & -8.418081 & 5.098273 & 2.8914 \\
\hline $\mathrm{H}$ & -10.858313 & 5.341007 & 2.71873 \\
\hline $\mathrm{H}$ & -12.133226 & 4.089036 & 0.9794 \\
\hline $\mathrm{H}$ & -10.938282 & 2.574376 & -0.5718 \\
\hline $\mathrm{H}$ & -5.209843 & 1.917153 & 4.2744 \\
\hline $\mathrm{H}$ & -0.422029 & 3.992359 & 0.8968 \\
\hline $\mathrm{H}$ & -2.849819 & 3.631806 & 0.7390 \\
\hline
\end{tabular}




$\begin{array}{rrrr}\mathrm{H} & 1.858293 & 3.079408 & 1.152756 \\ \mathrm{H} & -3.409245 & -1.171933 & 1.153908 \\ \mathrm{H} & 4.949153 & -9.513760 & 1.831364 \\ \mathrm{H} & 6.302839 & -8.334321 & 0.099779 \\ \mathrm{H} & 6.793602 & -5.938079 & 0.316414 \\ \mathrm{H} & 4.073993 & -8.252965 & 3.775513 \\ \mathrm{H} & 4.280375 & -3.725187 & 5.234489 \\ \mathrm{H} & 3.825066 & -6.141868 & 5.015435 \\ \mathrm{H} & 8.848736 & -1.544855 & -1.362013 \\ \mathrm{H} & 6.397022 & -1.254457 & -1.174436 \\ \mathrm{H} & 8.414713 & -5.097916 & 2.894866 \\ \mathrm{H} & 10.855090 & -5.340569 & 2.723960 \\ \mathrm{H} & 12.131170 & -4.088930 & 0.985285 \\ \mathrm{H} & 10.937255 & -2.574696 & -0.567236 \\ \mathrm{H} & 5.205138 & -1.916646 & 4.274768 \\ \mathrm{H} & 3.407421 & 1.171869 & 1.153483 \\ \mathrm{H} & -1.860093 & -3.079559 & 1.152878 \\ \mathrm{H} & 0.420088 & -3.992466 & 0.895396 \\ \mathrm{H} & 2.847965 & -3.631979 & 0.738654\end{array}$

Coordinates of $\mathbf{2}_{\text {ex }} \mathbf{L}$ in Figure 3.

$\begin{array}{llll}\mathrm{C} & 5.298571 & 7.315732 & 2.562261 \\ \mathrm{C} & 5.409696 & 6.438991 & 3.651205 \\ \mathrm{C} & 5.724121 & 5.106709 & 3.444184 \\ \mathrm{C} & 5.945988 & 4.598160 & 2.132638 \\ \mathrm{C} & 5.792108 & 5.497561 & 1.025257 \\ \mathrm{C} & 5.482671 & 6.842922 & 1.262854 \\ \mathrm{C} & 6.271037 & 3.230652 & 1.901016 \\ \mathrm{C} & 6.325270 & 2.768161 & 0.538283 \\ \mathrm{C} & 6.169815 & 3.673695 & -0.551766 \\ \mathrm{C} & 5.933235 & 4.994639 & -0.309788 \\ \mathrm{C} & 6.553446 & 2.295302 & 3.012410 \\ \mathrm{C} & 7.666702 & 2.546246 & 3.898834 \\ \mathrm{C} & 7.849904 & 1.710051 & 5.046043 \\ \mathrm{C} & 6.927381 & 0.657791 & 5.280550 \\ \mathrm{C} & 5.902041 & 0.403467 & 4.408436\end{array}$




\begin{tabular}{|c|c|c|c|}
\hline $\mathrm{C}$ & 5.726519 & 1.196683 & 3.247681 \\
\hline $\mathrm{C}$ & 8.640799 & 3.552689 & 3.655277 \\
\hline $\mathrm{C}$ & 9.704421 & 3.741438 & 4.512213 \\
\hline $\mathrm{C}$ & 9.859462 & 2.935284 & 5.661075 \\
\hline $\mathrm{C}$ & 8.948175 & 1.935622 & 5.91497 \\
\hline $\mathrm{O}$ & 6.574333 & 1.500039 & 0.344418 \\
\hline $\mathrm{O}$ & 4.647188 & 0.959279 & 2.433404 \\
\hline $\mathrm{C}$ & 4.434468 & -0.404465 & 2.065523 \\
\hline $\mathrm{O}$ & 5.432667 & -1.133404 & 2.057740 \\
\hline $\mathrm{C}$ & 3.080527 & -0.813669 & 1.824995 \\
\hline $\mathrm{C}$ & 1.912870 & 0.024031 & 1.634741 \\
\hline $\mathrm{C}$ & 0.609422 & -0.585902 & 1.730805 \\
\hline $\mathrm{C}$ & 0.484487 & -1.996866 & 1.927525 \\
\hline $\mathrm{C}$ & 1.659282 & -2.798269 & 1.984201 \\
\hline $\mathrm{C}$ & 2.897854 & -2.227936 & 1.921160 \\
\hline $\mathrm{C}$ & -0.800943 & -2.559187 & 2.073743 \\
\hline $\mathrm{C}$ & 1.974871 & 1.428859 & 1.4637 \\
\hline $\mathrm{H}$ & 5.054139 & 8.359626 & 2.7268 \\
\hline $\mathrm{H}$ & 5.240593 & 6.801669 & 4.659019 \\
\hline $\mathrm{H}$ & 5.790993 & 4.429877 & 4.286006 \\
\hline $\mathrm{H}$ & 5.375921 & 7.517554 & $0.41 \varepsilon$ \\
\hline $\mathrm{H}$ & 6.254678 & 3.282529 & -1.557014 \\
\hline $\mathrm{H}$ & 5.833987 & 5.689989 & -1.137736 \\
\hline $\mathrm{H}$ & 7.050573 & 0.039815 & 6.16 \\
\hline $\mathrm{H}$ & 5.206925 & -0.405211 & 4.592371 \\
\hline $\mathrm{H}$ & 8.561276 & 4.174018 & 2.770793 \\
\hline $\mathrm{H}$ & 10.435453 & 4.514319 & 4.294573 \\
\hline $\mathrm{H}$ & 10.699836 & 3.096336 & 6.328658 \\
\hline $\mathrm{H}$ & 9.062276 & 1.290675 & 6.781781 \\
\hline $\mathrm{H}$ & 6.316029 & 1.209599 & -0.58491 \\
\hline $\mathrm{H}$ & 1.555853 & -3.872612 & 2.1080 \\
\hline $\mathrm{H}$ & 3.780626 & -2.845249 & 2.013967 \\
\hline $\mathrm{H}$ & -0.883257 & -3.634044 & 2.2141 \\
\hline $\mathrm{H}$ & 2.938309 & 1.906182 & 1.37531 \\
\hline $\mathrm{C}$ & 4.187007 & -7.173596 & $-2.9542 ?$ \\
\hline $\mathrm{C}$ & 4.531698 & -6.266738 & -3.98 \\
\hline
\end{tabular}




\begin{tabular}{|c|c|c|c|}
\hline $\mathrm{C}$ & 5.086193 & -5.041116 & -3.686967 \\
\hline $\mathrm{C}$ & 5.326248 & -4.646511 & -2.34034 \\
\hline $\mathrm{C}$ & 4.962470 & -5.565062 & -1.300405 \\
\hline $\mathrm{C}$ & 4.399519 & -6.822739 & -1.640708 \\
\hline $\mathrm{C}$ & 5.892045 & -3.373222 & -1.99764 \\
\hline $\mathrm{C}$ & 6.024747 & -3.025455 & -0.657739 \\
\hline $\mathrm{C}$ & 5.691647 & -3.955339 & 0.36619 \\
\hline $\mathrm{C}$ & 5.178606 & -5.186625 & 0.05043 \\
\hline $\mathrm{C}$ & 6.380521 & -2.446339 & -3.06061 \\
\hline $\mathrm{C}$ & 7.566427 & -2.767883 & -3.81453 \\
\hline $\mathrm{C}$ & 7.999090 & -1.905004 & -4.8740 \\
\hline $\mathrm{C}$ & 7.249453 & -0.733934 & -5.16028 \\
\hline $\mathrm{C}$ & 6.142697 & -0.415829 & -4.4184 \\
\hline $\mathrm{C}$ & 5.733800 & -1.267772 & -3.36611 \\
\hline $\mathrm{C}$ & 8.349824 & -3.920199 & -3.5302 \\
\hline $\mathrm{C}$ & 9.482722 & -4.208282 & -4.25866 \\
\hline $\mathrm{C}$ & 9.895059 & -3.363757 & -5.31 \\
\hline $\mathrm{C}$ & 9.166323 & -2.235353 & -5.61193 \\
\hline $\mathrm{O}$ & 6.516137 & -1.801940 & -0.34012 \\
\hline $\mathrm{O}$ & 4.544266 & -0.933676 & -2.6898 \\
\hline $\mathrm{C}$ & 4.476904 & 0.271719 & -2.08 \\
\hline $\mathrm{O}$ & 5.497295 & 0.956883 & -1.925627 \\
\hline $\mathrm{C}$ & 0.669464 & 0.608774 & -1.631283 \\
\hline $\mathrm{C}$ & 1.955205 & -0.029025 & -1.5 \\
\hline $\mathrm{C}$ & 2.004749 & -1.448834 & -1.387527 \\
\hline $\mathrm{C}$ & -0.712097 & 2.614670 & -1.969416 \\
\hline $\mathrm{C}$ & 0.576266 & 2.016491 & -1.84746 \\
\hline $\mathrm{C}$ & 1.754050 & 2.777903 & -1.9642 \\
\hline $\mathrm{C}$ & 2.987974 & 2.164778 & -1.93412 \\
\hline $\mathrm{C}$ & 3.117722 & 0.766360 & -1.7963 \\
\hline $\mathrm{H}$ & 3.752912 & -8.137398 & -3.2026 \\
\hline $\mathrm{H}$ & 4.354412 & -6.538444 & -5.020 \\
\hline $\mathrm{H}$ & 5.337431 & -4.356516 & -4.4892 \\
\hline $\mathrm{H}$ & 4.133880 & -7.505222 & -0.83712 \\
\hline $\mathrm{H}$ & 5.857057 & -3.664931 & 1.3980 \\
\hline $\mathrm{H}$ & 4.928462 & -5.890549 & 0.8 \\
\hline
\end{tabular}




\begin{tabular}{|c|c|c|c|}
\hline$U$ & 7.565538 & -0.089435 & -5.975757 \\
\hline t & 5.565469 & 0.476653 & -4.630527 \\
\hline F & 8.046586 & -4.572457 & -2.720232 \\
\hline $\mathrm{H}$ & 10.066061 & -5.092185 & -4.018068 \\
\hline $\mathrm{H}$ & 10.787476 & -3.605181 & -5.884870 \\
\hline & 9.476094 & -1.573290 & -6.416465 \\
\hline F & 6.287688 & -1.592091 & 0.592265 \\
\hline $\mathrm{H}$ & 2.963647 & -1.942635 & -1.32096 \\
\hline $\mathrm{H}$ & -0.770935 & 3.691251 & -2.104554 \\
\hline $\mathrm{H}$ & 1.677831 & 3.850232 & -2.120062 \\
\hline $\mathrm{H}$ & 3.884460 & 2.748622 & -2.09714 \\
\hline $\mathrm{C}$ & -4.594309 & 7.435481 & -2.32350 \\
\hline $\mathrm{C}$ & -4.910323 & 6.621376 & -3.436318 \\
\hline $\mathrm{C}$ & -5.371760 & 5.335435 & -3.260847 \\
\hline 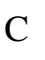 & -5.542188 & 4.782332 & -1.959246 \\
\hline $\mathrm{C}$ & -5.208277 & 5.609195 & -0.834919 \\
\hline $\mathrm{C}$ & -4.741800 & 6.931989 & -1.051080 \\
\hline $\mathrm{C}$ & -6.011918 & 3.444574 & -1.745588 \\
\hline $\mathrm{C}$ & -6.083434 & 2.946673 & -0.446681 \\
\hline $\mathrm{C}$ & -5.782070 & 3.785292 & 0.6 \\
\hline $\mathrm{C}$ & -5.358844 & 5.074982 & 0.471443 \\
\hline $\mathrm{C}$ & -6.463817 & 2.603734 & -2.895050 \\
\hline $\mathrm{C}$ & -7.699901 & 2.902591 & -3.572248 \\
\hline 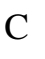 & -8.104413 & 2.119718 & -4.70 \\
\hline $\mathrm{C}$ & -7.277903 & 1.049113 & -5.134242 \\
\hline $\mathrm{C}$ & -6.117567 & 0.752402 & -4.468858 \\
\hline 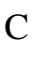 & -5.732739 & 1.526460 & -3.350485 \\
\hline $\mathrm{C}$ & -8.560011 & 3.951072 & -3.143988 \\
\hline$C$ & -9.740333 & 4.217494 & -3.801793 \\
\hline $\mathrm{C}$ & -10.126819 & 3.453543 & -4.927135 \\
\hline $\mathrm{C}$ & -9.323403 & 2.425847 & -5.3638 \\
\hline $\mathrm{O}$ & -6.480809 & 1.669438 & -0.25788 \\
\hline$\sigma$ & -4.497714 & 1.227261 & -2.7495 \\
\hline $\mathrm{C}$ & -4.362477 & 0.001431 & -2.1745 \\
\hline $\mathrm{O}$ & -5.315962 & -0.753734 & -2.05 \\
\hline $\mathrm{C}$ & -2.971001 & -0.388631 & -1.8089 \\
\hline
\end{tabular}




\begin{tabular}{|c|c|c|c|}
\hline $\mathrm{C}$ & -1.818250 & 0.449949 & -1.761903 \\
\hline $\mathrm{C}$ & -0.534004 & -0.163354 & -1.543085 \\
\hline $\mathrm{C}$ & -0.429700 & -1.580080 & -1.404550 \\
\hline $\mathrm{C}$ & -1.598187 & -2.355563 & -1.388447 \\
\hline $\mathrm{C}$ & -2.831984 & -1.770117 & -1.586415 \\
\hline $\mathrm{C}$ & 0.860531 & -2.182869 & -1.308353 \\
\hline$C$ & -1.856843 & 1.875658 & -1.928085 \\
\hline $\mathrm{H}$ & -4.236663 & 8.449568 & -2.476149 \\
\hline $\mathrm{H}$ & -4.787792 & 7.014497 & -4.441772 \\
\hline $\mathrm{H}$ & -5.606013 & 4.724640 & -4.125503 \\
\hline $\mathrm{H}$ & -4.500385 & 7.542780 & -0.184277 \\
\hline $\mathrm{H}$ & -5.896598 & 3.375575 & 1.661911 \\
\hline $\mathrm{H}$ & -5.133812 & 5.706606 & 1.327221 \\
\hline $\mathrm{H}$ & -7.580263 & 0.461816 & -5.99675 \\
\hline п & -5.483013 & -0.067510 & -4.785026 \\
\hline $\mathrm{H}$ & -8.277883 & 4.538606 & -2.278525 \\
\hline $\mathrm{H}$ & -10.382422 & 5.019931 & -3.450419 \\
\hline $\mathrm{H}$ & -11.058892 & 3.675446 & -5.438539 \\
\hline $\mathrm{H}$ & -9.613094 & 1.824333 & -6.221684 \\
\hline $\mathrm{H}$ & -6.255837 & 1.371985 & 0.650482 \\
\hline 11 & -1.523217 & -3.428886 & -1.24405 \\
\hline $\mathrm{H}$ & -3.722471 & -2.383611 & -1.601169 \\
\hline $\mathrm{H}$ & 0.916782 & -3.258732 & -1.175674 \\
\hline $\mathrm{H}$ & -2.812609 & 2.367446 & -2.028 \\
\hline $\mathrm{C}$ & -4.580500 & -7.268176 & 2.297186 \\
\hline $\mathrm{C}$ & -4.925147 & -6.472658 & 3.415325 \\
\hline$C$ & -5.425509 & -5.200538 & 3.248231 \\
\hline $\mathrm{C}$ & -5.608799 & -4.643903 & 1.949977 \\
\hline $\mathrm{C}$ & -5.246318 & -5.451339 & 0.820183 \\
\hline $\mathrm{C}$ & -4.739414 & -6.760901 & 1.027980 \\
\hline $\mathrm{C}$ & -6.118484 & -3.320092 & 1.746393 \\
\hline $\mathrm{C}$ & -6.209992 & -2.818929 & 0.451621 \\
\hline $\mathrm{C}$ & -5.876362 & -3.635209 & -0.665124 \\
\hline $\mathrm{C}$ & -5.408415 & -4.911883 & -0.482116 \\
\hline $\mathrm{C}$ & -6.577653 & -2.488279 & 2.89964 \\
\hline $\mathrm{C}$ & -7.811625 & -2.796192 & 3.573 \\
\hline
\end{tabular}




\begin{tabular}{|c|c|c|c|}
\hline $\mathrm{C}$ & -8.225830 & -2.011208 & 4.69916 \\
\hline $\mathrm{C}$ & -7.407621 & -0.932508 & 5.1262 \\
\hline $\mathrm{C}$ & -6.245515 & -0.632089 & 4.465676 \\
\hline $\mathrm{C}$ & -5.847643 & -1.406941 & 3.35080 \\
\hline $\mathrm{C}$ & -8.660162 & -3.856250 & 3.1503 \\
\hline $\mathrm{C}$ & -9.839292 & -4.130766 & 3.80710 \\
\hline $\mathrm{C}$ & -10.236430 & -3.363080 & 4.92626 \\
\hline $\mathrm{C}$ & -9.443733 & -2.324901 & 5.35830 \\
\hline $\mathrm{O}$ & -6.662667 & -1.554505 & 0.27427 \\
\hline $\mathrm{O}$ & -4.613526 & -1.124533 & 2.757919 \\
\hline $\mathrm{C}$ & -4.420105 & 0.131107 & 2.24215 \\
\hline $\mathrm{O}$ & -5.371177 & 0.909494 & 2.14406 \\
\hline $\mathrm{C}$ & -0.582039 & 0.211616 & $1.6628 \mathrm{~s}$ \\
\hline $\mathrm{C}$ & -1.883315 & -0.380477 & 1.88066 \\
\hline $\mathrm{C}$ & -1.942315 & -1.791850 & 2.052636 \\
\hline $\mathrm{C}$ & 0.835424 & 2.196580 & 1.410000 \\
\hline $\mathrm{C}$ & -0.453369 & 1.629189 & 152 \\
\hline $\mathrm{C}$ & -1.618924 & 2.431720 & 1.5035 \\
\hline $\mathrm{C}$ & -2.856454 & 1.871211 & 1.68848 \\
\hline $\mathrm{C}$ & -3.035178 & 0.485360 & 1.91209 \\
\hline $\mathrm{H}$ & -4.190468 & -8.271104 & 2.4 \\
\hline $\mathrm{H}$ & -4.792422 & -6.869482 & 4.417965 \\
\hline $\mathrm{H}$ & -5.681110 & -4.602422 & 4.115639 \\
\hline $\mathrm{H}$ & -4.475204 & -7.357 & 0.10 \\
\hline $\mathrm{H}$ & -6.003608 & -3.224643 & -1.661343 \\
\hline $\mathrm{H}$ & -5.159659 & -5.528851 & -1.342053 \\
\hline $\mathrm{H}$ & -7.717398 & -0.342680 & 5.9 \\
\hline $\mathrm{H}$ & -5.618657 & 0.193470 & 4.7811 \\
\hline $\mathrm{H}$ & -8.369098 & -4.447534 & 2.290137 \\
\hline $\mathrm{H}$ & -10.471699 & -4.942948 & 3.4602 \\
\hline $\mathrm{H}$ & -11.167371 & -3.591138 & 5.4371 \\
\hline $\mathrm{H}$ & -9.741038 & -1.721329 & 6.2122 \\
\hline $\mathrm{H}$ & -6.420838 & -1.232837 & -0.6144 \\
\hline $\mathrm{H}$ & -2.902036 & -2.269506 & 2.1765 \\
\hline $\mathrm{H}$ & 0.914302 & 3.272466 & 1.2807 \\
\hline$U$ & -1.520435 & 3.504193 & 1.3 \\
\hline
\end{tabular}


$\begin{array}{llll}\mathrm{H} & -3.733979 & 2.502204 & 1.701003\end{array}$

Coordinates of $\mathbf{7}_{\mathrm{ex}} \underline{\mathbf{R}}$ in Figure S16.

\begin{tabular}{|c|c|c|c|}
\hline $\mathrm{C}$ & -4.624747 & 8.795711 & 2.496736 \\
\hline $\mathrm{C}$ & -5.458994 & 8.209441 & 1.513539 \\
\hline $\mathrm{C}$ & -5.796227 & 6.877107 & 1.57890 \\
\hline $\mathrm{C}$ & -5.319751 & 6.046705 & 2.635196 \\
\hline $\mathrm{C}$ & -4.461555 & 6.642582 & 3.62031 \\
\hline $\mathrm{C}$ & -4.137562 & 8.022966 & 3.52410 \\
\hline $\mathrm{C}$ & -5.650508 & 4.659545 & 2.72862 \\
\hline $\mathrm{C}$ & -5.105223 & 3.900920 & 3.76315 \\
\hline $\mathrm{C}$ & -4.255980 & 4.490752 & 4.733113 \\
\hline $\mathrm{C}$ & -3.950468 & 5.829261 & 4.66011 \\
\hline $\mathrm{C}$ & -6.538877 & 3.997752 & 1.724301 \\
\hline $\mathrm{C}$ & -7.952553 & 4.241292 & 1.6955 \\
\hline $\mathrm{C}$ & -8.762454 & 3.595204 & 0.703412 \\
\hline $\mathrm{C}$ & -8.145090 & 2.719743 & -0.22803 \\
\hline $\mathrm{C}$ & -6.794993 & 2.478844 & -0.181467 \\
\hline $\mathrm{C}$ & -6.001194 & 3.115429 & 0.801802 \\
\hline $\mathrm{C}$ & -8.597178 & 5.093745 & 2.635026 \\
\hline $\mathrm{C}$ & -9.957031 & 5.305435 & 2.58 \\
\hline $\mathrm{C}$ & -10.750272 & 4.678671 & 1.598405 \\
\hline $\mathrm{C}$ & -10.161105 & 3.841188 & 0.679473 \\
\hline $\mathrm{O}$ & -5.446214 & 2.581865 & 3.78 \\
\hline $\mathrm{O}$ & -4.628407 & 2.941541 & 0.807912 \\
\hline $\mathrm{C}$ & -4.095554 & 1.658508 & 0.950059 \\
\hline $\mathrm{O}$ & -4.834733 & 0.680778 & 0.965940 \\
\hline $\mathrm{C}$ & -2.641472 & 1.690570 & 1.039078 \\
\hline $\mathrm{C}$ & -1.858771 & 0.479041 & 1.165507 \\
\hline $\mathrm{C}$ & -0.421514 & 0.571894 & 1.099976 \\
\hline $\mathrm{C}$ & 0.212624 & 1.849718 & 0.978112 \\
\hline $\mathrm{C}$ & -0.596156 & 3.021399 & 0.933080 \\
\hline $\mathrm{C}$ & -1.966191 & 2.936416 & 0.9563 \\
\hline $\mathrm{C}$ & 1.620376 & 1.907716 & 0.9005 \\
\hline $\mathrm{C}$ & -2.429665 & -0.808660 & 1.342513 \\
\hline $\mathrm{C}$ & 4.554150 & -8.693887 & 2.95 \\
\hline
\end{tabular}




\begin{tabular}{|c|c|c|c|}
\hline $\mathrm{C}$ & 5.362320 & -8.218162 & 1.894402 \\
\hline $\mathrm{C}$ & 5.713182 & -6.890010 & 1.81636 \\
\hline $\mathrm{C}$ & 5.277265 & -5.953141 & 2.798527 \\
\hline $\mathrm{C}$ & 4.445114 & -6.437971 & 3.863625 \\
\hline $\mathrm{C}$ & 4.106229 & -7.817159 & 3.91547 \\
\hline $\mathrm{C}$ & 5.622780 & -4.567487 & 2.74311 \\
\hline $\mathrm{C}$ & 5.115815 & -3.703163 & 3.71218 \\
\hline $\mathrm{C}$ & 4.292126 & -4.183673 & 4.76127 \\
\hline $\mathrm{C}$ & 3.973602 & -5.519243 & 4.831867 \\
\hline $\mathrm{C}$ & 6.486697 & -4.019850 & 1.652402 \\
\hline $\mathrm{C}$ & 7.896546 & -4.281938 & 1.608190 \\
\hline $\mathrm{C}$ & 8.682990 & -3.745921 & 0.534899 \\
\hline $\mathrm{C}$ & 8.046877 & -2.958651 & -0.460109 \\
\hline $\mathrm{C}$ & 6.700662 & -2.698755 & -0.40013 \\
\hline $\mathrm{C}$ & 5.929858 & -3.226881 & 0.662191 \\
\hline $\mathrm{C}$ & 8.560497 & -5.045718 & 2.608597 \\
\hline $\mathrm{C}$ & 9.916389 & -5.276955 & 2.544565 \\
\hline $\mathrm{C}$ & 10.686190 & -4.759449 & 1.476133 \\
\hline $\mathrm{C}$ & 10.078256 & -4.009317 & 0.496140 \\
\hline $\mathrm{O}$ & 5.467370 & -2.391801 & 3.593012 \\
\hline $\mathrm{O}$ & 4.558553 & -3.037880 & 0.693134 \\
\hline $\mathrm{C}$ & 4.037829 & -1.741095 & 0.746355 \\
\hline $\mathrm{O}$ & 4.773915 & -0.773395 & 0.581621 \\
\hline $\mathrm{C}$ & 0.390814 & -0.612187 & 1.124744 \\
\hline $\mathrm{C}$ & 1.825661 & -0.524136 & 1.01837 \\
\hline $\mathrm{C}$ & 2.401736 & 0.769950 & 0.940257 \\
\hline $\mathrm{C}$ & -1.646707 & -1.945084 & 1.372783 \\
\hline $\mathrm{C}$ & -0.246420 & -1.890324 & 1.22 \\
\hline $\mathrm{C}$ & 0.551531 & -3.069640 & 1.160467 \\
\hline $\mathrm{C}$ & 1.918440 & -2.993992 & 1.057396 \\
\hline $\mathrm{C}$ & 2.599688 & -1.750909 & 0.9655 \\
\hline $\mathrm{H}$ & -4.370615 & 9.849692 & 2.43356 \\
\hline $\mathrm{H}$ & -5.836307 & 8.819493 & 0.6975 \\
\hline $\mathrm{H}$ & -6.433027 & 6.441415 & 0.817 \\
\hline $\mathrm{H}$ & -3.490215 & 8.456515 & 4.2825 \\
\hline $\mathrm{H}$ & -3.847128 & 3.888489 & 5.5352 \\
\hline
\end{tabular}




\begin{tabular}{|c|c|c|c|}
\hline $\mathrm{H}$ & -3.301275 & 6.277070 & 5.407992 \\
\hline $\mathrm{H}$ & -8.759617 & 2.236314 & .9 \\
\hline $\mathrm{H}$ & -6.321432 & 1.804075 & -0.883326 \\
\hline $\mathrm{H}$ & -7.999036 & 5.575256 & 3.40029 \\
\hline $\mathrm{H}$ & -10.425939 & 5.958097 & 3.3189 \\
\hline $\mathrm{H}$ & -11.821377 & 4.856447 & 1.57017 \\
\hline $\mathrm{H}$ & -10.760842 & 3.347850 & -0.08145 \\
\hline $\mathrm{H}$ & -0.108534 & 3.990959 & 08770 \\
\hline $\mathrm{H}$ & -2.560788 & 3.839904 & 0.90729 \\
\hline $\mathrm{H}$ & 2.097452 & 2.881735 & 0.82497 \\
\hline $\mathrm{H}$ & -3.501311 & -0.887571 & 1.44482 \\
\hline $\mathrm{H}$ & 4.288814 & -9.745798 & 3.00580 \\
\hline $\mathrm{H}$ & 5.708484 & -8.910715 & 1.13225 \\
\hline $\mathrm{H}$ & 6.329740 & -6.539877 & 0.9963 \\
\hline $\mathrm{H}$ & 3.479036 & -8.165422 & 4.73251 \\
\hline $\mathrm{H}$ & 3.912506 & -3.499873 & 5.510627 \\
\hline $\mathrm{H}$ & 3.344032 & -5.882706 & 5.63 \\
\hline $\mathrm{H}$ & 8.643818 & -2.557030 & -1.27459 \\
\hline $\mathrm{H}$ & 6.214891 & -2.087964 & -1.150205 \\
\hline $\mathrm{H}$ & 7.980514 & -5.442987 & 3.43382 \\
\hline $\mathrm{H}$ & 10.400498 & -5.860405 & 3.52 \\
\hline $\mathrm{H}$ & 11.754391 & -4.951697 & 1.435632 \\
\hline $\mathrm{H}$ & 10.660009 & -3.599937 & -0.326045 \\
\hline $\mathrm{H}$ & 3.476766 & $0.0 \mathrm{~J}$ & 0.03 \\
\hline $\mathrm{H}$ & -2.119618 & -2.917160 & 1.48949 \\
\hline $\mathrm{H}$ & 0.062548 & -4.036302 & 1.248937 \\
\hline $\mathrm{H}$ & 2.506080 & -3.903307 & 1.035092 \\
\hline $\mathrm{C}$ & 2.462458 & 7.611448 & -0.240683 \\
\hline $\mathrm{C}$ & 3.234051 & 6.679768 & 0.49693 \\
\hline $\mathrm{C}$ & 4.210696 & 5.930180 & -0.117773 \\
\hline $\mathrm{C}$ & 4.473028 & 6.066227 & -1.5118 \\
\hline $\mathrm{C}$ & 3.693489 & 7.016680 & -2.25394 \\
\hline $\mathrm{C}$ & 2.692839 & 7.774437 & -1.5860 \\
\hline $\mathrm{C}$ & 5.473305 & 5.295821 & -2.1812 \\
\hline $\mathrm{C}$ & 5.680906 & 5.484793 & -3.5464 \\
\hline$C$ & 4.915435 & 6.431003 & -4.27 \\
\hline
\end{tabular}




\begin{tabular}{|c|c|c|c|}
\hline $\mathrm{C}$ & 3.947306 & 7.171950 & -3.63854 \\
\hline $\mathrm{C}$ & 6.287213 & 4.276270 & -1.449852 \\
\hline $\mathrm{C}$ & 7.636339 & 4.539868 & -1.040034 \\
\hline $\mathrm{C}$ & 8.374989 & 3.520803 & -0.35319 \\
\hline $\mathrm{C}$ & 7.752639 & 2.273512 & -0.079 \\
\hline $\mathrm{C}$ & 6.457141 & 2.026956 & -0.46150 \\
\hline $\mathrm{C}$ & 5.754341 & 3.040271 & -1.14786 \\
\hline $\mathrm{C}$ & 8.271593 & 5.786945 & -1.2855 \\
\hline $\mathrm{C}$ & 9.568107 & 6.013260 & -0.88075 \\
\hline $\mathrm{C}$ & 10.298480 & 5.004742 & -0.20911 \\
\hline $\mathrm{C}$ & 9.711098 & 3.787573 & 0.0485 \\
\hline $\mathrm{O}$ & 6.643755 & 4.708460 & -4.12163 \\
\hline $\mathrm{O}$ & 4.397833 & 2.828609 & -1.46746 \\
\hline $\mathrm{C}$ & 4.059576 & 1.830474 & -2.31100 \\
\hline $\mathrm{O}$ & 4.835809 & 1.094457 & -2.87576 \\
\hline $\mathrm{C}$ & 2.565376 & 1.774152 & -2.46643 \\
\hline $\mathrm{C}$ & 1.888899 & 0.513695 & -2.50 \\
\hline $\mathrm{C}$ & 0.463984 & 0.509915 & -2.59 \\
\hline $\mathrm{C}$ & -0.244091 & 1.733901 & -2.75247 \\
\hline $\mathrm{C}$ & 0.477215 & 2.951408 & -2.77355 \\
\hline $\mathrm{C}$ & 1.854872 & 2.968845 & -2.59 \\
\hline $\mathrm{C}$ & -1.659199 & 1.706944 & -2.831455 \\
\hline $\mathrm{C}$ & 2.572087 & -0.725817 & -2.393407 \\
\hline $\mathrm{C}$ & -2.738047 & -7.886535 & 03 \\
\hline $\mathrm{C}$ & -3.488272 & -6.957083 & 0.42878 \\
\hline $\mathrm{C}$ & -4.379012 & -6.102573 & -0.179880 \\
\hline $\mathrm{C}$ & -4.571311 & -6.124942 & -1.59196 \\
\hline $\mathrm{C}$ & -3.812943 & -7.072665 & -2.3590 \\
\hline $\mathrm{C}$ & -2.902310 & -7.940442 & -1.69693 \\
\hline $\mathrm{C}$ & -5.482846 & -5.246214 & -2.2544 \\
\hline $\mathrm{C}$ & -5.625861 & -5.328558 & -3.6386 \\
\hline $\mathrm{C}$ & -4.879651 & -6.270177 & -4.3933 \\
\hline $\mathrm{C}$ & -3.996879 & -7.115097 & -3.762 \\
\hline $\mathrm{C}$ & -6.272631 & -4.227631 & -1.4959 \\
\hline $\mathrm{C}$ & -7.660122 & -4.424607 & -1.1876 \\
\hline$C$ & -8.375567 & -3.405628 & -0.47 \\
\hline
\end{tabular}




\begin{tabular}{|c|c|c|c|}
\hline $\mathrm{C}$ & -7.694961 & -2.223950 & -0.07801 \\
\hline $\mathrm{C}$ & -6.363741 & -2.043842 & 026177 \\
\hline $\mathrm{C}$ & -5.683334 & -3.055337 & $0^{\circ}$ \\
\hline $\mathrm{C}$ & -8.356678 & -5.606035 & -1.55914 \\
\hline $\mathrm{C}$ & -9.688468 & -5.770268 & 1.25050 \\
\hline $\mathrm{C}$ & -10.395187 & -4.761615 & $-0.5541^{\prime}$ \\
\hline $\mathrm{C}$ & -9.749353 & -3.607328 & -0.17577 \\
\hline $\mathrm{O}$ & -6.509431 & -4.458290 & -4.2048 \\
\hline $\mathrm{O}$ & -4.298235 & -2.896217 & -1.28192 \\
\hline $\mathrm{C}$ & -3.876869 & -1.982184 & -2.18224 \\
\hline $\mathrm{O}$ & -4.604048 & -1.306182 & -2.87492 \\
\hline $\mathrm{C}$ & -0.258238 & -0.707325 & -2.46151 \\
\hline $\mathrm{C}$ & -1.686239 & -0.704200 & -2.47883 \\
\hline $\mathrm{C}$ & -2.362231 & 0.529226 & -2.696 \\
\hline $\mathrm{C}$ & 1.870673 & -1.906366 & -2.26254 \\
\hline $\mathrm{C}$ & 0.454471 & -1.920500 & -2.2449 \\
\hline $\mathrm{C}$ & -0.267291 & -3.104639 & -1.963094 \\
\hline $\mathrm{C}$ & -1.657619 & -3.102700 & 10 \\
\hline $\mathrm{C}$ & -2.373665 & -1.933339 & -2.20892 \\
\hline $\mathrm{H}$ & 1.695542 & 8.194702 & 0.25970 \\
\hline $\mathrm{H}$ & 3.054009 & 6.558611 & 1.56105 \\
\hline $\mathrm{H}$ & 4.797513 & 5.224756 & 0.4 \\
\hline $\mathrm{H}$ & 2.112644 & 8.490083 & -2.16327 \\
\hline $\mathrm{H}$ & 5.087226 & 6.570890 & -5.33579 \\
\hline $\mathrm{H}$ & 3.362843 & 7.894158 & -4.2025 \\
\hline $\mathrm{H}$ & 8.313472 & 1.508002 & 0.4489 \\
\hline $\mathrm{H}$ & 5.972774 & 1.082068 & -0.238590 \\
\hline $\mathrm{H}$ & 7.715363 & 6.566190 & -1.79 \\
\hline $\mathrm{H}$ & 10.034731 & 6.974325 & $-1.0765 t$ \\
\hline $\mathrm{H}$ & 11.320460 & 5.195877 & 0.10448 \\
\hline $\mathrm{H}$ & 10.261557 & 3.007752 & 0.56809 \\
\hline $\mathrm{H}$ & -0.067071 & 3.883722 & -2.8858 \\
\hline $\mathrm{H}$ & 2.388051 & 3.910827 & -2.5536 \\
\hline $\mathrm{H}$ & -2.196119 & 2.640884 & -2.9626 \\
\hline $\mathrm{H}$ & 3.652193 & -0.730440 & -2.3617 \\
\hline $\mathrm{H}$ & -2.039939 & -8.554014 & 0.1629 \\
\hline
\end{tabular}




\begin{tabular}{lrrr}
$\mathrm{H}$ & -3.361182 & -6.921557 & 1.506834 \\
$\mathrm{H}$ & -4.951085 & -5.400174 & 0.415973 \\
$\mathrm{H}$ & -2.337267 & -8.652089 & -2.293751 \\
$\mathrm{H}$ & -4.999690 & -6.324983 & -5.468379 \\
$\mathrm{H}$ & -3.426772 & -7.833151 & -4.346051 \\
$\mathrm{H}$ & -8.238532 & -1.457072 & 0.466246 \\
$\mathrm{H}$ & -5.832474 & -1.152618 & -0.042522 \\
$\mathrm{H}$ & -7.819374 & -6.385517 & -2.088226 \\
$\mathrm{H}$ & -10.201602 & -6.682162 & -1.541874 \\
$\mathrm{H}$ & -11.445472 & -4.903310 & -0.317147 \\
$\mathrm{H}$ & -10.281406 & -2.828397 & 0.363931 \\
$\mathrm{H}$ & -3.441928 & 0.533677 & -2.740559 \\
$\mathrm{H}$ & 2.408196 & -2.836744 & -2.117859 \\
$\mathrm{H}$ & 0.278253 & -4.019230 & -1.762162 \\
$\mathrm{H}$ & -2.199519 & -4.010158 & -1.710297 \\
$\mathrm{C}$ & -6.697745 & -4.475999 & -5.611215 \\
$\mathrm{H}$ & -7.433943 & -3.699007 & -5.819841 \\
$\mathrm{H}$ & -5.769986 & -4.244522 & -6.149396 \\
$\mathrm{H}$ & -7.085835 & -5.441746 & -5.958954 \\
$\mathrm{C}$ & 4.832883 & -1.422956 & 4.416113 \\
$\mathrm{H}$ & 5.187031 & -0.456903 & 4.055310 \\
$\mathrm{H}$ & 3.741939 & -1.463612 & 4.317612 \\
$\mathrm{H}$ & 5.110801 & -1.539726 & 5.471540 \\
$\mathrm{H}$ & -4.773536 & 1.703525 & 4.677455 \\
$\mathrm{H}$ & -5.019736 & 1.918019 & 5.725480 \\
$\mathrm{H}$ & -5.125381 & 0.703629 & 4.422044 \\
$\mathrm{H}$ & -3.686624 & 1.746224 & 4.541002 \\
$\mathrm{H}$ & 6.920442 & 4.857130 & -5.505616 \\
$\mathrm{H}$ & -266078 & 5.870427 & -5.746010 \\
$\mathrm{H}$ & -5.14630 & 4.146073 & -5.725104 \\
$\mathrm{H}$ & 4.617634 & -6.124363 \\
\hline
\end{tabular}

Coordinates of $\mathbf{7}_{\mathrm{ex}} \mathbf{L}$ in Figure S16.

$\begin{array}{llll}\mathrm{C} & 5.106955 & 7.127284 & -0.336227 \\ \mathrm{C} & 6.015707 & 6.044187 & -0.251417 \\ \mathrm{C} & 5.994270 & 5.030537 & -1.181650\end{array}$




\begin{tabular}{|c|c|c|c|}
\hline $\mathrm{C}$ & 5.056333 & 5.041465 & -2.254203 \\
\hline $\mathrm{C}$ & 4.133242 & 6.137817 & -2.333569 \\
\hline $\mathrm{C}$ & 4.186238 & 7.168052 & -1.356244 \\
\hline $\mathrm{C}$ & 5.011747 & 4.008605 & -3.240164 \\
\hline $\mathrm{C}$ & 4.059366 & 4.073620 & -4.252759 \\
\hline $\mathrm{C}$ & 3.147484 & 5.156580 & -4.329597 \\
\hline $\mathrm{C}$ & 3.192074 & 6.160684 & -3.390610 \\
\hline $\mathrm{C}$ & 5.984073 & 2.872226 & -3.209818 \\
\hline $\mathrm{C}$ & 7.201648 & 2.922942 & -3.967364 \\
\hline $\mathrm{C}$ & 8.116578 & 1.820946 & -3.907036 \\
\hline $\mathrm{C}$ & 7.799068 & 0.700634 & -3.093728 \\
\hline $\mathrm{C}$ & 6.633064 & 0.656640 & -2.371217 \\
\hline $\mathrm{C}$ & 5.740104 & 1.748875 & -2.446657 \\
\hline $\mathrm{C}$ & 7.541044 & 4.038241 & -4.780604 \\
\hline $\mathrm{C}$ & 8.716941 & 4.062316 & -5.497031 \\
\hline $\mathrm{C}$ & 9.616635 & 2.972114 & -5.439543 \\
\hline $\mathrm{C}$ & 9.319434 & 1.877833 & -4.660013 \\
\hline $\mathrm{O}$ & 4.056723 & 3.036017 & -5.145735 \\
\hline $\mathrm{O}$ & 4.502022 & 1.664305 & -1.791995 \\
\hline $\mathrm{C}$ & 4.481599 & 1.639630 & -0.427077 \\
\hline $\mathrm{O}$ & 5.508900 & 1.673980 & 0.227871 \\
\hline $\mathrm{C}$ & 3.122908 & 1.589612 & 0.182092 \\
\hline $\mathrm{C}$ & 1.849869 & 1.680115 & -0.493092 \\
\hline $\mathrm{C}$ & 0.648924 & 1.706981 & 0.30 \\
\hline $\mathrm{C}$ & 0.734575 & 1.711514 & 1.729792 \\
\hline $\mathrm{C}$ & 2.009834 & 1.650582 & 2.348492 \\
\hline $\mathrm{C}$ & 3.156532 & 1.593165 & 1.593604 \\
\hline $\mathrm{C}$ & -0.451697 & 1.756643 & 2.492080 \\
\hline $\mathrm{C}$ & 1.700568 & 1.731776 & -1.907890 \\
\hline $\mathrm{H}$ & 5.138536 & 7.919272 & 0.406076 \\
\hline $\mathrm{H}$ & 6.736712 & 6.011629 & 0.560205 \\
\hline $\mathrm{H}$ & 6.686049 & 4.200283 & -1.096263 \\
\hline $\mathrm{H}$ & 3.480122 & 7.991228 & -1.431533 \\
\hline $\mathrm{H}$ & 2.412060 & 5.197679 & -5.123772 \\
\hline $\mathrm{H}$ & 2.491747 & 6.989334 & -3.453644 \\
\hline $\mathrm{H}$ & 8.498024 & -0.129881 & -3.04 \\
\hline
\end{tabular}




\begin{tabular}{|c|c|c|c|}
\hline $\mathrm{I}$ & 6.387182 & -0.189607 & -1.739685 \\
\hline H & 6.857608 & 4.879086 & -4.826045 \\
\hline $\mathrm{H}$ & 8.957570 & 4.925827 & -6.110479 \\
\hline $\mathrm{H}$ & 10.540829 & 3.003210 & -6.009144 \\
\hline $\mathrm{H}$ & 10.004947 & 1.035982 & -4.606327 \\
\hline $\mathrm{H}$ & 2.069294 & 1.655976 & 3.432999 \\
\hline 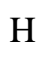 & 4.126666 & 1.557248 & 2.072282 \\
\hline $\mathrm{H}$ & -0.370073 & 1.787413 & 3.575332 \\
\hline $\mathrm{H}$ & 2.577348 & 1.751942 & -2.534007 \\
\hline $\mathrm{C}$ & 5.107177 & -7.127108 & 0.335633 \\
\hline $\mathrm{C}$ & 6.015884 & -6.043952 & 0.251089 \\
\hline $\mathrm{C}$ & 5.994301 & -5.030454 & 1.181483 \\
\hline $\mathrm{C}$ & 5.056256 & -5.041606 & 2.253941 \\
\hline $\mathrm{C}$ & 4.133205 & -6.138010 & 2.333032 \\
\hline $\mathrm{C}$ & 4.186353 & -7.168084 & 1.355547 \\
\hline $\mathrm{C}$ & 5.011529 & -4.008912 & 3.240062 \\
\hline $\mathrm{C}$ & 4.059066 & -4.074137 & 4.252569 \\
\hline $\mathrm{C}$ & 3.147209 & -5.157140 & 4.329122 \\
\hline $\mathrm{C}$ & 3.191925 & -6.161082 & 3.389970 \\
\hline $\mathrm{C}$ & 5.983785 & -2.872463 & 3.209986 \\
\hline $\mathrm{C}$ & 7.201313 & -2.923202 & 3.967607 \\
\hline $\mathrm{C}$ & 8.116152 & -1.821124 & 3.907541 \\
\hline $\mathrm{C}$ & 7.798619 & -0.700705 & 3.094382 \\
\hline $\mathrm{C}$ & 6.632672 & 6699 & 2.371782 \\
\hline $\mathrm{C}$ & 5.739784 & -1.749011 & 2.446983 \\
\hline $\mathrm{C}$ & 7.540732 & -4.038620 & 4.780676 \\
\hline $\mathrm{C}$ & 8.716575 & -4.062728 & 5.497190 \\
\hline $\mathrm{C}$ & 9.616183 & -2.972440 & 5.439963 \\
\hline $\mathrm{C}$ & 9.318953 & -1.878046 & 4.660603 \\
\hline $\mathrm{O}$ & 4.056319 & -3.036713 & 5.145743 \\
\hline $\mathrm{O}$ & 4.501750 & -1.664430 & 1.792232 \\
\hline $\mathrm{C}$ & 4.481454 & -1.639545 & 0.427307 \\
\hline $\mathrm{O}$ & 5.508853 & -1.673683 & -0.227521 \\
\hline $\mathrm{C}$ & 0.648853 & -1.706954 & -0.304834 \\
\hline $\mathrm{C}$ & 1.849763 & -1.680130 & 0.493156 \\
\hline $\mathrm{C}$ & 1.700398 & -1.731785 & 1.907946 \\
\hline
\end{tabular}




\begin{tabular}{|c|c|c|c|}
\hline $\mathrm{C}$ & -0.451677 & -1.756529 & -2.492121 \\
\hline $\mathrm{C}$ & 0.734569 & -1.711475 & 1.7297 \\
\hline $\mathrm{C}$ & 2.009861 & -1.650582 & -2.348424 \\
\hline $\mathrm{C}$ & 3.156520 & -1.593173 & -1.59348 \\
\hline $\mathrm{C}$ & 3.122831 & -1.589613 & -0.1819 \\
\hline $\mathrm{H}$ & 5.138872 & -7.918976 & -0.40679 \\
\hline $\mathrm{H}$ & 6.736971 & -6.011229 & -0.56045 \\
\hline $\mathrm{H}$ & 6.686038 & -4.200145 & 1.09630 \\
\hline $\mathrm{H}$ & 3.480269 & -7.991305 & 1.43062 \\
\hline $\mathrm{H}$ & 2.411691 & -5.198387 & 5.12320 \\
\hline $\mathrm{H}$ & 2.491609 & -6.989759 & 3.45278 \\
\hline $\mathrm{H}$ & 8.497510 & 0.129874 & 3.04708 \\
\hline $\mathrm{H}$ & 6.386814 & 0.189611 & 1.74032 \\
\hline $\mathrm{H}$ & 6.857350 & -4.879520 & 4.82591 \\
\hline $\mathrm{H}$ & 8.957229 & -4.926329 & 6.11050 \\
\hline $\mathrm{H}$ & 10.540336 & -3.003560 & 6.009627 \\
\hline $\mathrm{H}$ & 10.004400 & -1.036127 & 460 \\
\hline $\mathrm{H}$ & 2.577159 & -1.751962 & 2.5340 \\
\hline $\mathrm{H}$ & -0.370005 & -1.787257 & -3.575372 \\
\hline $\mathrm{H}$ & 2.069375 & -1.655991 & -3.43293 \\
\hline $\mathrm{H}$ & 4.126683 & -1.557283 & -2.07 \\
\hline $\mathrm{C}$ & -5.114015 & -7.130320 & -0.334668 \\
\hline $\mathrm{C}$ & -6.021593 & -6.046173 & -0.250665 \\
\hline $\mathrm{C}$ & -5.998069 & -5.032488 & $-1.10000 /$ \\
\hline $\mathrm{C}$ & -5.059107 & -5.044442 & -2.252454 \\
\hline $\mathrm{C}$ & -4.137180 & -6.141833 & -2.330972 \\
\hline $\mathrm{C}$ & -4.192335 & -7.172076 & -1.353775 \\
\hline $\mathrm{C}$ & -5.012387 & -4.011579 & -3.2383 \\
\hline $\mathrm{C}$ & -4.059035 & -4.077555 & -4.249918 \\
\hline $\mathrm{C}$ & -3.148277 & -5.161522 & -4.3258 \\
\hline $\mathrm{C}$ & -3.194962 & -6.165665 & -3.38705 \\
\hline $\mathrm{C}$ & -5.983517 & -2.874154 & -3.2088 \\
\hline $\mathrm{C}$ & -7.200949 & -2.923972 & -3.96 \\
\hline $\mathrm{C}$ & -8.114759 & -1.821006 & -3.9070 \\
\hline $\mathrm{C}$ & -7.796297 & -0.700635 & -3.0942 \\
\hline$C$ & -6.630403 & -0.657482 & -2.37 \\
\hline
\end{tabular}




\begin{tabular}{|c|c|c|c|}
\hline $\mathrm{C}$ & -5.738546 & -1.750670 & -2.44621 \\
\hline $\mathrm{C}$ & -7.541266 & -4.039297 & 477050 \\
\hline $\mathrm{C}$ & -8.717006 & -4.062501 & -5.49 \\
\hline $\mathrm{C}$ & -9.615605 & -2.971359 & -5.43944 \\
\hline $\mathrm{C}$ & -9.317484 & -1.877019 & -4.66034 \\
\hline $\mathrm{O}$ & -4.054318 & -3.039892 & -5 \\
\hline $\mathrm{O}$ & -4.500504 & -1.667016 & -1.79139 \\
\hline $\mathrm{C}$ & -4.480299 & -1.641529 & -0.42648 \\
\hline $\mathrm{O}$ & -5.507756 & -1.674702 & 0.22 \\
\hline $\mathrm{C}$ & -3.121678 & -1.592107 & 0.1827 \\
\hline $\mathrm{C}$ & -1.848597 & -1.681660 & -0.49232 \\
\hline $\mathrm{C}$ & -0.647669 & -1.707412 & 0.3056 \\
\hline $\mathrm{C}$ & -0.733385 & -1.711671 & 1.73062 \\
\hline $\mathrm{C}$ & -2.008681 & -1.651488 & 2.3492 \\
\hline $\mathrm{C}$ & -3.155388 & -1.595065 & 1.59428 \\
\hline $\mathrm{C}$ & 0.452899 & -1.755743 & 2.4929 \\
\hline $\mathrm{C}$ & -1.699189 & -1.733398 & -1.90714 \\
\hline $\mathrm{H}$ & -5.147243 & -7.922326 & 0.407544 \\
\hline $\mathrm{H}$ & -6.743341 & -6.012831 & 0.56026 \\
\hline $\mathrm{H}$ & -6.688940 & -4.201415 & -1.09603 \\
\hline $\mathrm{H}$ & -3.487092 & -7.996060 & -1.42841 \\
\hline $\mathrm{H}$ & -2.412059 & -5.203358 & -5.1 \\
\hline $\mathrm{H}$ & -2.495495 & -6.995090 & -3.449445 \\
\hline $\mathrm{H}$ & -8.494423 & 0.130608 & -3.047289 \\
\hline $\mathrm{H}$ & -6.383855 & 0.188821 & -1.74029 \\
\hline $\mathrm{H}$ & -6.858655 & -4.880841 & -4.8243 \\
\hline $\mathrm{H}$ & -8.958356 & -4.926041 & -6.109340 \\
\hline $\mathrm{H}$ & -10.539689 & -3.001775 & -6.00 \\
\hline $\mathrm{H}$ & -10.002152 & -1.034443 & -4.60722 \\
\hline $\mathrm{H}$ & -2.068190 & -1.656565 & 3.43377 \\
\hline $\mathrm{H}$ & -4.125583 & -1.559455 & 2.0728 \\
\hline $\mathrm{H}$ & 0.371271 & -1.786391 & 3.5762 \\
\hline $\mathrm{H}$ & -2.575938 & -1.754340 & -2.5332 \\
\hline $\mathrm{C}$ & -5.111922 & 7.130230 & 0.3346 \\
\hline $\mathrm{C}$ & -6.019732 & 6.046302 & 0.2503 \\
\hline $\mathrm{C}$ & -5.996822 & 5.032659 & 1.1805 \\
\hline
\end{tabular}




\begin{tabular}{|c|c|c|c|}
\hline $\mathrm{C}$ & -5.058274 & 5.044434 & 2.252578 \\
\hline $\mathrm{C}$ & -4.136121 & 6.141614 & 2.331408 \\
\hline $\mathrm{C}$ & -4.190636 & 7.171817 & 1.354134 \\
\hline $\mathrm{C}$ & -5.012184 & 4.011608 & 3.238500 \\
\hline $\mathrm{C}$ & -4.059238 & 4.077434 & 4.250507 \\
\hline $\mathrm{C}$ & -3.148266 & 5.161199 & 4.326803 \\
\hline $\mathrm{C}$ & -3.194330 & 6.165292 & 3.38787 \\
\hline $\mathrm{C}$ & -5.983531 & 2.874378 & 3.208707 \\
\hline $\mathrm{C}$ & -7.201035 & 2.924274 & 3.96641 \\
\hline $\mathrm{C}$ & -8.115031 & 1.821480 & 3.906543 \\
\hline $\mathrm{C}$ & -7.796677 & 0.701195 & 3.0935 \\
\hline $\mathrm{C}$ & -6.630724 & 0.657970 & 2.370883 \\
\hline $\mathrm{C}$ & -5.738692 & 1.750996 & 2.445876 \\
\hline $\mathrm{C}$ & -7.541252 & 4.039519 & 4.77938 \\
\hline $\mathrm{C}$ & -8.717066 & 4.062803 & 5.49598 \\
\hline $\mathrm{C}$ & -9.615845 & 2.971823 & 5.438929 \\
\hline $\mathrm{C}$ & -9.317827 & 1.877568 & 4650 \\
\hline $\mathrm{O}$ & -4.055122 & 3.039815 & 5.143454 \\
\hline $\mathrm{O}$ & -4.500612 & 1.667276 & 1.791129 \\
\hline $\mathrm{C}$ & -4.480282 & 1.642007 & 0.426235 \\
\hline $\mathrm{O}$ & -5.507656 & 1.675404 & -0.228 \\
\hline $\mathrm{C}$ & -0.647571 & 1.707512 & -0.305717 \\
\hline $\mathrm{C}$ & -1.848538 & 1.681846 & 0.492228 \\
\hline $\mathrm{C}$ & -1.699185 & 1.733579 & 1.90 \\
\hline $\mathrm{C}$ & 0.453096 & 1.755794 & -2.492954 \\
\hline $\mathrm{C}$ & -0.733223 & 1.711784 & -1.730671 \\
\hline $\mathrm{C}$ & -2.008491 & 1.651687 & -2.349373 \\
\hline $\mathrm{C}$ & -3.155241 & 1.595366 & -1.594442 \\
\hline $\mathrm{C}$ & -3.121598 & 1.592416 & -0.182958 \\
\hline $\mathrm{H}$ & -5.144663 & 7.922203 & -0.407607 \\
\hline $\mathrm{H}$ & -6.741179 & 6.013097 & -0.56084 \\
\hline $\mathrm{H}$ & -6.687877 & 4.201762 & 1.095572 \\
\hline $\mathrm{H}$ & -3.485226 & 7.995635 & 1.4290 \\
\hline $\mathrm{H}$ & -2.412375 & 5.202919 & 5.1205 \\
\hline $\mathrm{H}$ & -2.494699 & 6.994562 & 3.45050 \\
\hline $\mathrm{H}$ & -8.494930 & -0.129929 & 3.04 \\
\hline
\end{tabular}




\begin{tabular}{lrrr}
$\mathrm{H}$ & -6.384242 & -0.188284 & 1.739588 \\
$\mathrm{H}$ & -6.858510 & 4.880945 & 4.824497 \\
$\mathrm{H}$ & -8.958337 & 4.926283 & 6.109219 \\
$\mathrm{H}$ & -10.539984 & 3.002300 & 6.008651 \\
$\mathrm{H}$ & -10.002632 & 1.035118 & 4.606333 \\
$\mathrm{H}$ & -2.575954 & 1.754594 & 2.533159 \\
$\mathrm{H}$ & 0.371516 & 1.786455 & -3.576212 \\
$\mathrm{H}$ & -2.067948 & 1.656761 & -3.433883 \\
$\mathrm{H}$ & -4.125417 & 1.559842 & -2.073077 \\
$\mathrm{C}$ & 3.193031 & -3.099984 & 6.268780 \\
$\mathrm{H}$ & 3.386756 & -3.987976 & 6.883648 \\
$\mathrm{H}$ & 3.404279 & -2.205730 & 6.857037 \\
$\mathrm{H}$ & 2.135128 & -3.093114 & 5.974870 \\
$\mathrm{C}$ & 3.193555 & 3.099070 & -6.268881 \\
$\mathrm{H}$ & 3.404845 & 2.204684 & -6.856921 \\
$\mathrm{H}$ & 3.387370 & 3.986928 & -6.883914 \\
$\mathrm{H}$ & 2.135620 & 3.092287 & -5.975087 \\
$\mathrm{C}$ & -3.191218 & 3.103554 & 6.265996 \\
$\mathrm{H}$ & -3.385355 & 3.991222 & 6.881202 \\
$\mathrm{H}$ & -3.401341 & 2.208967 & 6.854150 \\
$\mathrm{H}$ & -2.133488 & 3.097682 & 5.971451 \\
$\mathrm{C}$ & -3.189944 & -3.103759 & -6.264980 \\
$\mathrm{H}$ & -3.399622 & -2.209101 & -6.853184 \\
$\mathrm{H}$ & -2.132340 & -3.098128 & -5.969974 \\
& -3.384002 & -3.991356 & -6.880314 \\
& & & \\
\hline
\end{tabular}




\section{References}

(S1) Wu, T. R.; Shen, L.; Chong, J. M. Asymmetric allylboration of aldehydes and ketones using 3,3'-disubstituted binaphthol-modified boronates. Org. Lett. 2004, 6, 2701-2704.

(S2) Hrdina, R.; Guénée, L.; Moraleda, D.; Lacour, J. Synthesis, structural analysis, and catalytic properties of tetrakis(binaphthyl or octahydrobinaphthyl phosphate) dirhodium(II,II) complexes. Organometallics 2013, 32, 473-479.

(S3) Reeder, J.; Castro, P. P.; Knobler, C. B. Chiral recognition of cinchona alkaloids at the minor and major grooves of 1,1'-binaphthyl receptors. J. Org. Chem. 1994, 59, 3151-3160.

(S4) Zhou, Y.; Zhang, D.; Zhu, L.; Shuai, Z.; Zhu, D. Binaphthalene molecules with tetrathiafulvalene units: $\mathrm{CD}$ spectrum modulation and new chiral molecular switches by reversible oxidation and reduction of tetrathiafulvalene units. J. Org. Chem. 2006, 71, 2123-2130.

(S5) Abreu, A. R.; Pereira, M. M.; Bayón, J. C. Synthesis of new bis-BINOL-2,2'-ethers and bis- $\mathrm{H}_{8} \mathrm{BINOL}-2,2^{\prime}$-ethers evaluation of their titanium complexes in the asymmetric ethylation of benzaldehyde. Tetrahedron 2010, 66, 743-749.

(S6) Zou, L.; Wang, X.-Y.; Zhang, X.-X.; Dai, Y.-Z.; Wu, Y.-D.; Wang, J.-Y.; Pei, J. Toward electron-deficient pyrene derivatives: Construction of pyrene tetracarboxylic diimide containing five-membered imide rings. Chem. Commun. 2015, 51, 12585-12588.

(S7)Driscoll, P. F.; Douglass, E. F., Jr.; Phewluangdee, M.; Soto, E. R.; Cooper, C. G. F.; MacDonald, J. C.; Lambert, C. R.; McGimpsey, W. G. Photocurrent generation in noncovalently assembled multilayered thin films. Langmuir 2008, 24, 5140-5145. 